Portland State University

PDXScholar

7-30-1991

\title{
A Comparative Analysis of U.S. Foreign Policy in Iran and the Philippines
}

Christina M. Blumel

Portland State University

Follow this and additional works at: https://pdxscholar.library.pdx.edu/open_access_etds

Part of the Political Science Commons

Let us know how access to this document benefits you.

\section{Recommended Citation}

Blumel, Christina M., "A Comparative Analysis of U.S. Foreign Policy in Iran and the Philippines" (1991). Dissertations and Theses. Paper 4295.

https://doi.org/10.15760/etd.6179

This Thesis is brought to you for free and open access. It has been accepted for inclusion in Dissertations and Theses by an authorized administrator of PDXScholar. Please contact us if we can make this document more accessible: pdxscholar@pdx.edu. 
AN ABSTRACT OF THE THESIS OF Christina M. Blumel for the Master of Arts in Political science presented July 30 , 1991.

Title: A Comparative Analysis of U.S. Foreign Policy in Iran and The Philippines

APPROVED BY THE MEMBERS OF THE THESIS COMMITTEE:

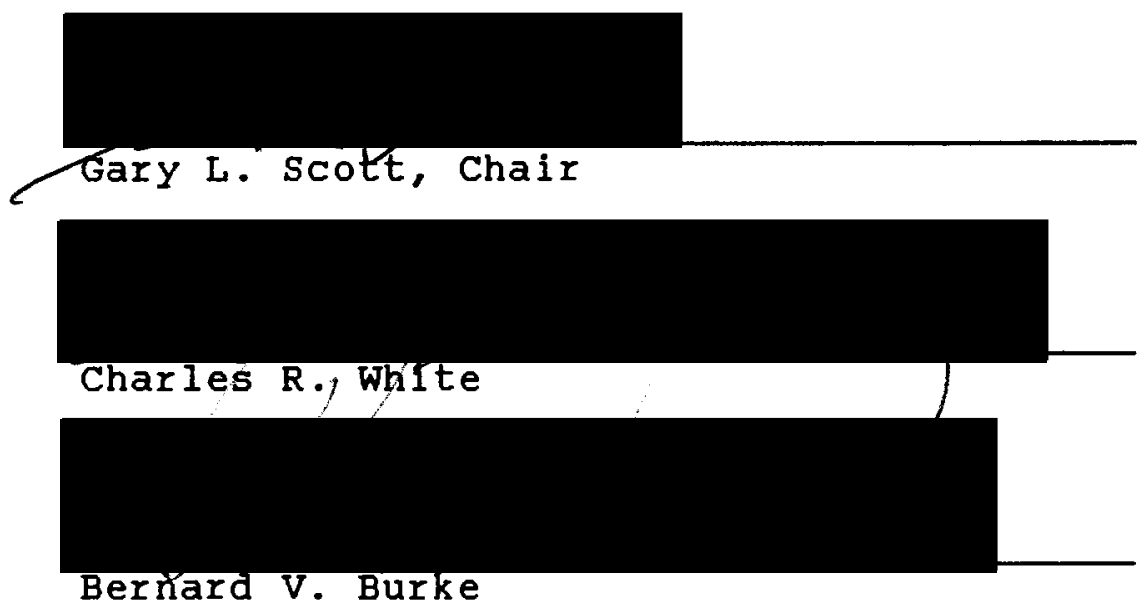

This paper is a comparative analysis of U.S. forelgn policy towards Iran and the Philippines. The question which prompted this research topic was simple: why was the outcome for the United states so different in terms of subsequent relations with each state after the downfall of the Shah and Ferdinand Marcos? Both leaders were important U.S. allies in strategic states that had benefitted from foreign aid. Opposition groups in each state resented this support of 
their repressive leaders. Unlike Iran, good relations with the Philippines continued during the Aquino presidency, without the resentment and mistrust which prevented good relations after the Shah's departure.

In order to explore this question, the U.S. relationship with each state is divided into an examination of two time periods. The tenure period encompasses the point from which each leader assumed power until the start of the events which ultimately led to the end of their regimes. For the Shah, this was from the 1953 coup overthrowing Mossadeq until to the visit from President Carter in 1978. For President Marcos, this was from the Presidential election of 1969 to the assassination of Benigno Aquino in 1983. The crisis period begins from the end of the tenure periods to the departure of each leader. For the Shah this was November 4, 1979; for President Marcos, February 24, 1986.

While the crisis period comparison relies primarily on an examination of events, the tenure period uses a framework developed by Barry Goldstone in an essay entitled "Revolutions and superpowers." Goldstone asserts that in modern neopatrimonial regimes such as Iran and the Philippines, dictators centralize power around themselves in patronage networks, and use foreign aid to support their regimes. The assertion is that foreign aid is used by the United states to augment the resources of these regimes, in order to maintain leaders which are sympathetic to U.S. 
interests. Ultimately, these leaders rely too much on U.S. support, and fail to develop the mass support needed to maintain their regimes. Leaders become over identified with United states, being perceived as relying on U.S. support to maintain their positions. This framework provides a way in which to compare different states using a consistent measuring stick in terms of U.S. foreign policy and regime failure.

The use of two time periods is augmented by a comparison of four additional elements: the historical relationship with the United States, the U.S. presence in each country, the pressure role of religion in politics, and the role of miliary training provided by U.S. personnel. They were chosen because they seemed to provide important points of comparison, which might prove to be crucial differences in how each state related to the United states during each regime.

The analysis concludes that the timing of foreign aid was more important than long-term U.S. support of each leader. Marcos and the Shah became over identified with the United states because support was given during a period of regime consolidation. However, the legacy of the long-term relationship with the U.S., in terms of tolerance for U.S. influence in Philippine affairs moderated the response of the Aquino regime. Also, there was little understanding regarding the nature of the Iranian revolution and radical 
position of Khomeini's followers. In both states, the relationship created during the tenure period affected the range of choices that policy makers were aware of during the final crisis, and the amount of leverage that the United states could use successfully. 
A COMPARATIVE ANALYSIS OF U.S. FOREIGN POLICY IN IRAN AND THE PHILIPPINES

by

CHRISTINA M. BLUMEL

A thesis submitted in partial fulfillment of the requirements for the degree of

\author{
MASTER OF ARTS \\ in \\ POLITICAL SCIENCE
}

Portland state University

1991 
TO THE OFFICE OF GRADUATE STUDIES:

The members of the committee approve the thesis of Christina M. Blumel presented July 30, 1991.

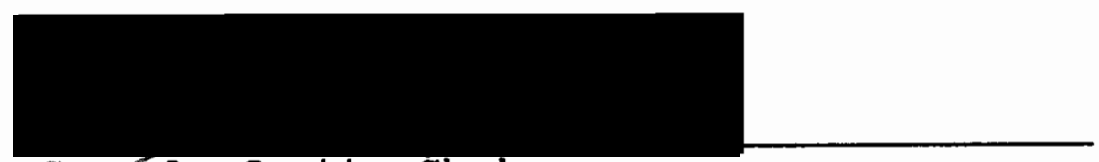

Gagey L. Scott, Chair

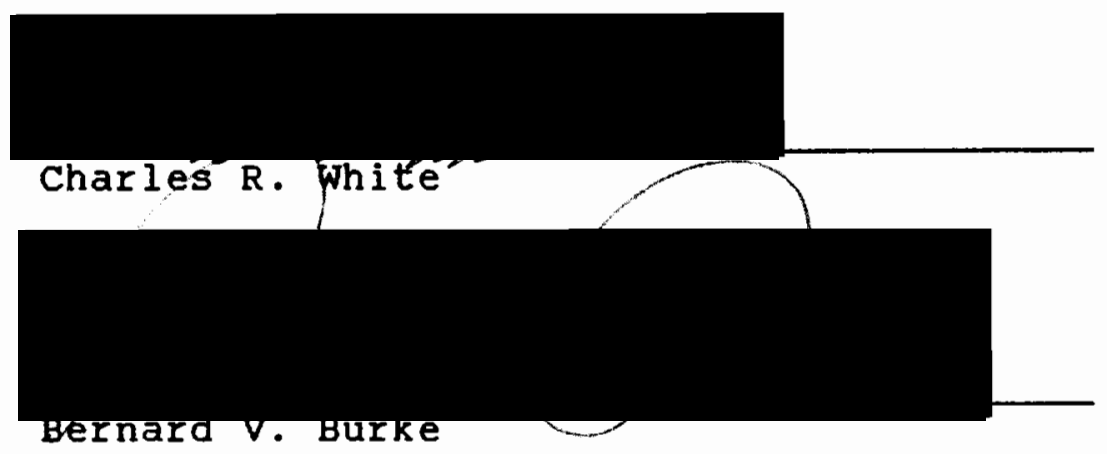

APPROVED :

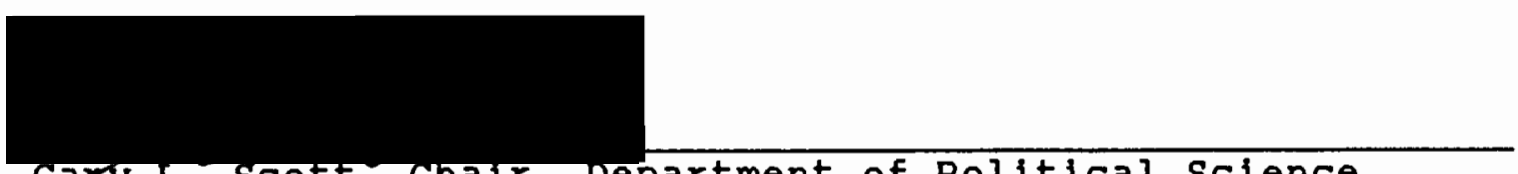

Gaxy L. scott, Chair, Department of Political science

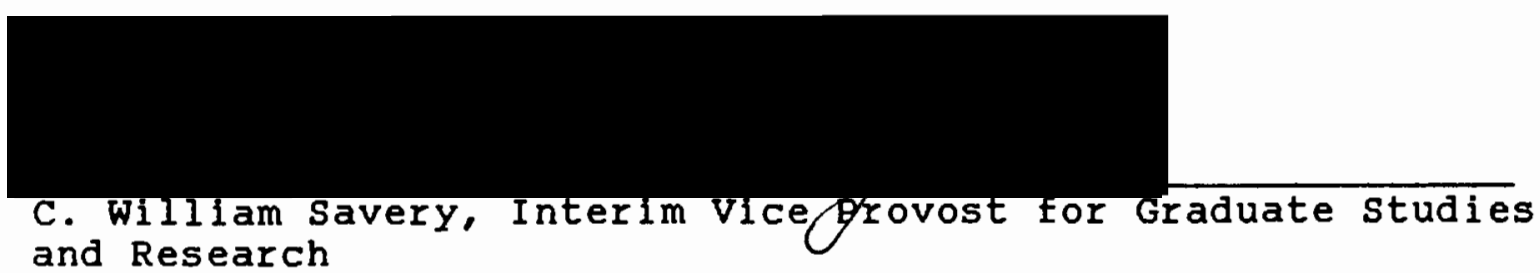




\section{ACKNOWLEDGEMENTS}

I would like to thank $\mathrm{Dr}$. Scott and $\mathrm{Dr}$. White for their phenomenal patience. I would also like to thank minother, father. sister, and Kelly for love and forbearance while this was being completed. 
TABLE OF CONTENTS

PAGE

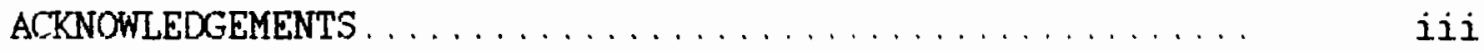

CHAPTER

I

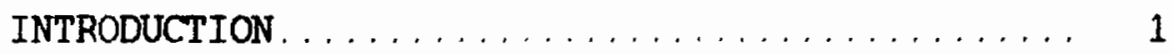

The Research Ouestion............... 3

The Case for Comparability............. 4

The Research Method ................. 7

Review of U.S. Foreign Aid ............ 13

Economic Politics/Political Realities..... 29

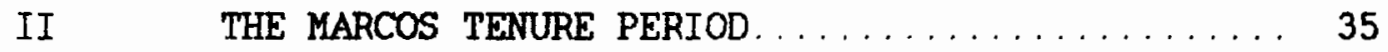

Early U.S. /Philippine History. .......... 35

Reconstruction and Independence......... 38

The Hukbalahaps, U.S. Intervention,

Growing Nationalism................., 43

Marcos Regime Prior to Martial Law........ 50

Martial Law....................... 55

III THE SHAH'S TENURE PERIOD .............. 60

The Early Relationship..............., 60

The Nationalist Movement and Mossadeq...... 68

Consolidation of Power ............... 76

The White Revolution............... 81 
Oil Revenues, Military Purchases, and

the Appearance of Absolute Control........ 88

IV TENURE COMPARISON $\ldots \ldots \ldots \ldots \ldots \ldots \ldots \ldots \ldots$

The Philippines................... 97

$\operatorname{Iran} \ldots \ldots \ldots \ldots \ldots \ldots \ldots \ldots \ldots$

$\mathrm{V}$ THE CRISIS PERIOD: HISTORY AND COMPARISON ....... 116

The Iranian Crisis................... 116

The Philippine Crisis................ 144

Analysis and Comparison of

the Crisis Period.................... 160

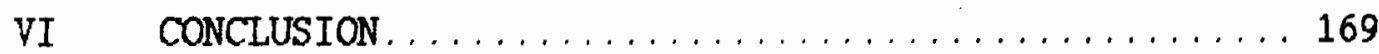

Tenure Versus Crisis................ 170

Over Identification................ 175

Future Recommendations............ 177

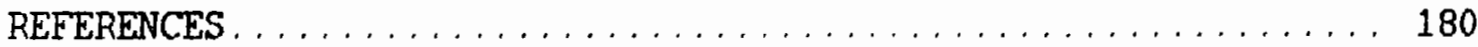


CHAPTER I

INTRODUCTION

The United States has confronted a dilemma in its longterm relationships with authoritarian Third world states. support for authoritarian regimes may benefit the United states in the short-term, ensuring access to trade and the maintenance of a non-communist regime in addition to security conslderations. However, when these reglmes fall, the United states becomes the scapegoat of the new government, blamed for supporting a corrupt and repressive rule which sacrificed the interests of the citizenry. As a result, the United states finds 1 tself unable to effectively pursue a satisfactory relationship with the new government. These forfeltures are especially important when they involve states of strategic importance. While occasional losses cause immediate difficulties, a series of them damages the prestige of the United states as a superpower. This pattern of supporting repressive regimes, which are replaced by nonfriendly regimes has been evident from vietnam to Iran, El Salvador, and Nicaragua.

Long-term support, outside of active intervention by the CIA, has involved official transfers of large amounts of military and financial ald for three purposes. First, it is 
in U.S. interests to keep these friendly authoritarian regimes stable, since they pursue military and economic policles that are perceived to benefit U.S. Interests. Financial and military support can fill in the capability gaps resulting from a lack of resources; such gaps can weaken a leader's power, leading to instability. Second, these regimes are in de facto control of the states they govern, in the sense that these authoritarian leaders have initially created and maintained their own power bases. Despite charges by opposition groups that United states' support keeps these regimes alive far past their natural political lives, the United states cannot create an authoritarian leader who manages that support to ensure his political longevity.

Finally, the strategy of containing communism has proved to be an overriding concern for U.S. policy makers, and the U.S. has taken the position that authoritarian dictators are preferable to communist regimes. It can be argued that U.S. policy makers perceived the cold war world in zero-sum terms; the loss of an ally meant a gain for the U.S.S.R. In addition, support could be fustified because Third World states were percelved to be in a pre-modern stage; modern economic development would lead to political development. Democracy would prevall, with enough economic support and protection from communist influences, as a result of the modernization process. 
Another aspect of this support involves the United states changing perception of commitment, and the relative balance of bargaining power. Many of these relationships began when the weaker parties were unable to effectively exploit their importance to U.S. interests. However, as the relationship progressed, two things occurred. The authoritarian leader became more aware of the state's importance to U.S. Interests and better able to negotiate with U.S. policy makers. second, U.S. policy makers developed a familiarity with a particular leader; the pattern of the relationship became a known and calculable quantity, enabling policy makers to better calculate current and future support for U.S. interests.

\section{THE RESEARCH QUESTION}

Given these factors, is there any way to avoid the dilemma of short-term support incurring long-term costs? To explore the question, this paper will execute a comparative analysis of U.S. Intervention and influence in Iran during the reign of Shah Mohammed Reza Pahlavi, and in the Philippines during the rule of president Ferdinand Marcos. When the Shah fell from power, the United states was forced to terminate diplomatic relations with Iran after the hostage crisis, and was unable to negotiate any successful relationship with the successive regimes. The United states 
was blamed by the opposition for keeping the shah in power, and accorded responsiblity for training S.A.V.A.K., the Shah's secret police. In the Phillppines, the United states maintained good relations with the new Aquino government, despite the fact that the United states was blamed by the opposition for keeping Marcos in power through large amounts of military and financial aid.

There are two central questions. First, did differences in U.S. actions before or during the crisis provide a better explanation of these opposite outcomes? second, was the outcome determined by an accumulation of cultural, religious or historical factors that made it difficult to mitigate the opposition to the United states?

\section{THE CASE FOR COMPARABILITY}

In terms of comparablitty, these states appear to have very little in common. First, each has a distinct culture, religious orientation, and traditions. The Philippines was a former colony while Iran was not, although both experienced occupation during World War II, albeit by different sides in the conflict. Also, the Middle East and south Pacific are very different geopolitical spheres. Iran was a far more powerful state, economically and militarily, and dominated the region for these reasons. The shah actively pursued the role of regional leader for Iran. The Philippines, on the 
other hand, had been continuously engaged in a long running battle against different Communist insurgent groups, and continued to host two large United states military bases. It had no plans to be a reglonal leader, except in terms of being the leading regional U.S. ally.

However, both states have important similarities in terms of their relationship with the United states. First, Iran and the Philippines are strategically important. The Philippines' geographic location is ideal for the presence of Subic Naval Bage and Clark Air Field, which would cost the United states millions to recreate elsewhere. Iran was initially important because of lts border with the soviet Union, and it was percelved as vulnerable to soviet infiltration. Iran's importance evolved as it became a regional leader in the Middle East where it supported United States' interests. Iran became an exporter of large amounts of oil to the United states, and the Shah was leader in OPEC where the United states badly needed representation.

second, each state was ruled by authoritarian leaders whose regimes were marked by corruption, repression, and a continuing lack of development. While both the shah and Marcos promised economic and political reform, the reality was that little happened in terms of wealth redistribution or power sharing for the masses. Systems of corruption and patronage prevailed, and were reinforced. Also, both leaders spent large amounts of money on developing their military 
forces at the expense of domestic expenditure; each made up the short-fall in different ways, but the economy suffered. The rationale for the military bulld-up in the philippines was on counter-insurgency, while the purported focus in Iran was on outside threats from states like Iraq. However, both the shah and Ferdinand Marcos relied on the military as part of their power base. Each state devoted at least $15 \%$ of the state budget towards military development towards the end of their regimes at the expense of social investments such as housing and education.

Third, U.S. perception of these states is arguably very similar, particularly given a Cola war foreign policy. During the relevant time period, it can be argued that a bipolar zero-sum situation existed. In effect, loss of an ally meant a gain for the other slde, even if there was no official alliance with the U.S.S.R. following the fall of a pro-U.S. regime. A high U.S. priority was the maintenance and cultivation of non-communist allies. Later the loss was more critical in terms of strategic and economic interests, rather than the zero-sum, cold war calculus. In terms of the Philippines, the loss of the clark and subic Bay military bases would have been irreplaceable, particularly after the Soviet Union established naval operations in Cam Ranh Bay in Vietnam. In terms of Iran, the loss of a friendly, powerful ally in the Middle East that was also powerful within oPEC Introduced another type of uncertainty into Middle East 
relations, and pushed the United states to more strongly in accordance with other anti-Israeli allies.

While some of the comparability rests on the simllarities between developing states and authoritarian rulers, the focus of this study is the similarities and differences in U.S. treatment of each regime. Both states believed that they participated in a "special relationship" with the United states, while the United states pursued the most advantageous course according to cold war dictates, as well as strategic and economic interests.

\section{THE RESEARCH METHOD}

The analysis will examine two time perlods. The first encompasses the time in offlce of each leader up to the point when the crisis began. The second encompasses the period of crisis up until the point where the new government is installed, or diplomatic relations end. Hereafter they will be referred to as the tenure perlod and the crisis period. The reason for examining these two time periods is to determine whether something in the U.s. relationship during the tenure perlod or the crisis perlod provides a better explanation of the eventual outcome.

In the case of Iran, the tenure period begins with the restoration of the shah to power August, 1953 to the state visit of President Carter January 1, 1978. The crisis perlod 
begins with the demonstrations in the holy city of Qom, January 7, 1978 and concludes January 16, 1979 with the departure of the shah. The extended period of unrest prior to taking the hostages on November 04, 1979, is also briefly discussed, in order to demonstrate that the Ayatollah Khomeinl actually mobilized the citizenry, including the bureaucracy. The slow realization by U.S. policy makers of the scope and nature of the revolution may have been important in terms of lost opportunities for better relations.

For the Philippines, the tenure period begins with the election of Marcos to the presidency on November 9, 1969 and ends prior to the Aquino assassination. The crisis period begins with the assassination of Benigno Aquino on August 22, 1983, and ends with the departure of Ferdinand Marcos to Hawa11 on February 24, 1986. Although the crisis time period is much longer, the events are no less dramatic than the year of violence preceding the shah's departure.

The problem in examining the tenure perlod involves doing a comparison of the U.S. relationship with the two states that ensures the same perspective will be used to examine U.S. relations with each state. This analysis makes the assumption that each state fell within the same class from the U.S. perspective: countrles that were strategically as well as symbolically important in the context of the cold War, were led by authorltarian regimes supported by the 
United states, and experienced rapid dissolution. The examination of the tenure period relies on a framework developed by Jack Goldstone, in an essay entitled "Revolutions and superpowers."l The Goldstone framework provides a way to look at how forelgn aid works as a type of U.S. intervention into Third World states.

Goldstone describes the characteristics of modern neopatrimonial regimes, including in this category both Iran and the Philippines. Neopatrimonial regimes are characterized by elite and urban based support, rather than the mass support of the population. While they may have democratic forms such as congresses and parliaments, political power is actually restricted to a small elite group. There are four highly active elite segments: traditional oligarchs, new professionals, and the military and bureaucratic elites. A central chief executive acts as a power broker among these different groups. Furthermore, this chief executive depends primarily on a system of personal patronage and coercion to maintain state authority. While the state may have legislatures and political parties, real power is wielded by the central dictator.

However, in acting as the central power broker among these different groups, the chlef executive needs to dispense resources valued by the elite groups. These are

1 In Superpowers and Revolutions (Ed) Jonathan Adelman, (Praeger Publishers) 1986 . 
chiefly money (the lucrative aspects of locating a development project in someone's town, for example) and political prestige (becoming responsible for the administration of such projects, for example). One of the ways in which a leader's resources can be augmented is through foreign aid. Goldstone asserts that the U.S. encourages overreliance on foreign aid; because the U.S. gives such massive amounts, the need for the executive to build a non-elite support base is eliminated.

In addition, the U.S. may demand certain quid pro quos for their money which antagonize the nationalist feelings of elite groups. Reliance on forelgn ald can also lead to the perception that the chief executive is vulnerable because his only support is from the United States; he loses legitimacy through overidentification with a foreign power. Finally, if economic growth falters, he may lose donor support at the same time he is unable to provide fuel for the patronage machine which is his means of support. Thus economic and military aid can be particularly important in the political life of these leaders, and in the political aftermath for the United states.

In using this framework to analyze U.S. policy, the first question is whether the Shah and Marcos relied on foreign aid to maintain their regimes. The other aspect to this question is whether the opposition perceived this to be the case, thus affecting their desire to maintain relations 
on the same terms with the United states once the old regime had fallen. Also, did the United states demand onerous quid pro quos that antagonized opposition groups? If so, this may have changed over time, as each regime was better able to exploit its strategic and symbolic value to the United states.

The final question is whether the amount and type of U.S. aid provided allowed these leaders to avoid fiscal responsibility, to such an extent that they destroyed their legitimacy. When the economic downturn occurred, as it did for both states, there was nothing to fall back on. In addition, pressure from new classes, a power shift from one group to another, or dissatisfaction with the repressive regime, may have been more important in the eventual downfall of each leader, and the new government's opposition to the United States.

In addition to this framework, I propose to also look at some other factors. These include:

-historical relationship with the United States

-U.S. presence in the country

-the pressure role of religion in politics

-the role of military training provided by U.S. personnel

These factors may be important in terms of how the United states was percelved by the public and opposition groups in each country. For example, S.A.V.A.K., the shah's secret 
police, had benefitted from C.I.A. training, and the United states was widely blamed by Iranians for its creation and brutality. In the Philippines, there was a lot of resentment against the squalor and prostitution that surrounded the U.S. military bases. In addition, the base agreements created an extraterritoriality which was widely resented by many filipinos.

The second part of the analysis concerns events during the period of crisis and regime change. It is important to look at what the U.S. response was to regime breakdown and whether the U.S. sought to preserve the status quo of the old regime or encouraged the establishment of the new regime. The method of comparison will involve an examination of the historical record of events, which encompasses visits made by special envoys, state Department officials, embassy reports and presidential responses. In addition, the survey of statements made by those groups of individuals which assumed power during the regime change is a record of their perceptions of the United states and its role in supporting the departing leader or the new regime. Such perceptions of support may have significantly influenced the future course of relations.

In order to understand the context in which the United states began to provide military and economic assistance on a large-scale basis after world war II, the following brief historical account describes the perceived uses and perils 
of foreign aid transfers for the United states. The discussion focuses primarily on economic aid, since the security nature of military ald, and its role in containing counter-insurgency are fairly obvious.

REVIEW OF U.S. FOREIGN AID

The United states has always had a security orientation towards their aid programs. While this is obvious with military assistance programs, it is not as readily apparent with economic aid. The United states has long supported allies with economic as well as military assistance, nominally for development purposes. Economic assistance was supposed to promote U.S. security because economically strong and politically cohesive states were less likely to be vulnerable to subversion or external intervention. ${ }^{2} \mathrm{~T} \mathrm{~h}$ concerns about intervention began after world war II. Post war U.S. ald began with the Greek-Turkish aid program of 1947. The aid proposal was in response to the United Kingdom's inability to support the Greek government's fight against guerrillas believed to be supported by communist satellite states. ${ }^{3}$ Aid was also given to Turkey for the

2 Joan Nelson, Aid, Influence and Forelgn Policy (New York: Macmilian and Company, 1968), p. 13.

3 Robert A. Packenham, Liberal America and the Third World (Princeton: Princeton University Press, 1973), p. 27 . 
same purposes. 1 This aid package was the beginning of a policy which, in Truman's words, stated his belief that " we must assist free peoples to work out their own destinies in their own way. I believe that our help should be primarily through economic and financial aid which is essential to economic stability and orderly political processes." 5

In keeping with this belief, the Truman administration authorized the second major foreign aid program, the European Recovery Program, otherwise known as the Marshall Plan. It remains the most successful foreign aid program in history. $\$ 17$ billion dollars was appropriated in Congress for the European Recovery Act in March of 1948. By 1952, $\$ 4$ billion dollars under budget, almost all of the goals had been achieved. 6 Much of the Marshall Plan's success, however, can be attributed to the fact that economic aid was being given to states which already possessed the sophisticated economic systems and the technical expertise to rebuild them. ${ }^{7}$

The need for the Marshall plan, as well as increases in the foreign aid program, arose from the failure of post-war

1 David A. Baldwin, Foreign Aid and American Foreign Policy a Documentary Analysis (New York: Frederick A. Praeger, Publishers, 1966), P. 23.

5 Packenham, Liberal America, p. 26.

6 Packenham, Liberal America, p. 34.

1 Hans Morgenthau, A New Foreign Policy for the United States (New York: Praeger Publishers, 1969), p. 95. 
institutions such as the International Bank for Reconstruction and Development (IBRD), International Monetary Fund (IMF), and the International Trade Organization (ITO), and also of private investment to provide the capital for rebuilding war ravaged economies. Eastern Europe had already been dominated by the soviet Union; since most Western European states already had communist parties, U.S. policy makers believed it was vital that economic stability and prosperity be restored to prevent further Communist gains and soviet hegemony in Europe. ${ }^{8}$ Hans Morgenthau identifies the fifteen weeks in the spring of 1947 to the armistice of the Korean war as a phase of realization and adaption by U.S. policy makers to an expansionist Soviet Union.' The Marshall Plan was part of this response to the perception that the "political health in Europe depended on economic medicine." 10

The views of U.S. policy makers regarding the Marshall Plan have been explored by Gilbert winham in a content analysis of speeches by fourteen key policy makers involved

8 Packenham, Liberal America and the Third World, p. 33-34 .

9 Morgenthau, A New Foreign Policy for the United states, p. 84 .

${ }^{10}$ Packenham, p. 34 . 
in creating and advocating the Marshall Plan." His research confirms that economic considerations were most important to these decision makers. World economic health was perceived as of prime importance, and this could only be done with an economically healthy Europe. After this, the national interest was the most common theme to emerge; security considerations in terms of invasion or war with the U.S.S.R. became important after the Communist takeover in Czechoslovakia in February of 1948 . Humanitarian considerations rate last as an important reason to extend economic assistance.

During his inaugural address of 1949, Truman outlined the rationale for his enlargement of the financial ald program with the point Four Proposal. In points three and four, Truman discusses the arrangements that had been made to "provide unmistakable proof of the joint determination of the free countries to resist armed attack from any quarter"12, referring to the Rio pact and the soon to be finalized NATO agreement. This was the beginning of a web of treaties, designed to thwart soviet aggression through

11 Gilbert R. Winham, "Developing Theories of Foreign Policy Making: A Case study of Forelgn Ald" Journal of Politics, 32(1) (February, 1970) 41-70. 60.

12 Baldwin, Foreign Aid and American Foreign Policy, p. 
physical encirclement. 13 Truman also made explicit the U.S. planned to provide military advice and equipment to "free nations which will cooperate with us in the maintenance of peace and security"ll. Truman also made an explicit U.S. goal to create a new program to assist the less developed states, referring to the poverty that existed in much of the world. Truman's thesis was that democracy could only flourish where people had hope of a better life. He stated that

Democracy alone can supply the vitalizing force to stir the peoples of the world into triumphant action, not only against their human oppressors, but also against their ancient enemies--hunger, misery, and despair

The important aspect of Truman's Point Four is his linkage between peace, democracy and economic prosperity. The belief that the provision of U.S. foreign aid, with a strong reliance on technical assistance would reduce poverty, thereby reducing the appeal of communism would be more distinctly expressed as the Truman presidency progressed. The appropriation in 1950 for all foreign aid

13 Besides the R1o Pact and NATO, the United states was a signatory of ANZUS in 1951, and SEATO, 1954, and also the reconfiguration of the Baghdad Pact into CENTO, 1959. 61 .

14 Baldwin, Foreign Aid and American Foreign Policy, p. 62.

${ }^{15}$ Baldwin, Foreign Aid and American Foreign Policy, $p$. 
was a modest $\$ 34.5$ million. ${ }^{16}$ The amount was increased to $\$ 155.6$ milition by 1953; although this was negligible compared to the defense budget ${ }^{17}$, it does indicate a reliance on development to cure potential political problems. Economic development would provide an ounce of economic prevention as an antidote for the appeal of communism.

In the 1950s, aid to underdeveloped nations continued as a security measure. Truman's secretary of state, Dean Acheson, in a report to the senate Committee on Foreign Relations in 1950, made even more explicit the security orientation of foreign aid. Acheson specifically links the economic security of the Third World and U.S. security.

Increasing numbers of people no longer accept poverty as an inevitable fact of life. They are becoming aware of the gap between their living standards and those in the more highly developed countries. They are looking for a way out of their misery. They are not concerned with abstract ideas of democracy or communism. They are interested in practical solutions to their problems in terms of food, shelter, and a decent livelihood. When the Communists offer quick and easy remedies for all their $10^{i l l s, ~ t h e y ~ m a k e ~ a ~}$ strong appeal to these people. ${ }^{10}$

16 Thomas A. Bailey, A Diplomatic History of the American People (New York: Apple-Century-Crofts, 1964), p. 805 .

19 Thomas A. Bailey, A Diplomatic History of the American People, p. 805. 64 .

11 Baldwin, Foreign Aid and American Foreign Policy, p. 
He continues on that the appropriations for foreign aid are "In a very real sense...a security measure"19. While foreign aid amounts were not large compared to the 1960s, much of the aid to southeastern Asia and Latin America continued to be justified in this fashion.

Essentially, the Eisenhower administration didn't differ in its perception of what economic aid could accomplish, however, it reversed the ratio of economic to military aid. Instead of a ratio of four economic aid dollars to every one military aid dollar, the amount of military ald was on average twice the amount of economic aid for the remainder of the decade ${ }^{20}$. The Mutual security Act of 1951 created and governed three agencies: the Technical Cooperation Administration, the Mutual Defense Assistance Program and the Economic Cooperation Administration. The activities of these three agencies provided mutual security by ensuring military as well as economic advancement to "friendly countries". 21

The Foreign Operations Administration was created in 1953; direct military aid constituted seventy percent of the budget, while twenty percent was defense support. ${ }^{22}$ The idea was to create a 64.

${ }^{19}$ Baldwin, Forelgn Ald and American Foreign Policy, p.

${ }^{20}$ Packenham, Liberal America, p.49.

${ }^{21}$ Packenham, Liberal America, p. 50.

22w.w. Rostow, Eisenhower, Kennedy and Foreign Aid (Austin: University of Texas Press, 1985), p. 91. 
periphery beyond which the soviet union communism would not venture, as it did in the Korean war. ${ }^{23}$ It was abolished two years later, and responsibility was subsumed within the state Department. 21

with the Kennedy administration, a number of significant changes occurred in the forelgn ald program. A much greater emphasis was put on economic aid. The Forelgn Assistance Act of 1961 replaced the Mutual security Act as the fundamental legislation which governed aid programs. ${ }^{25}$ The goal was to make assistance into a coordinated program for each country that involved technical, capital and commodity assistance. ${ }^{26}$ Countries needed to modernize in terms of their entire social structure and way of $11 \mathrm{fe}$, in order to enable them to reach the "take-off" into selfsustaining growth. 27 It was in the United states best interests to increase the pace of development. A nation absorbed in internal political development would be less likely to look for external scapegoats, and was less likely to fall prey to internal subversion or external

23 Rostow, Eisenhower, Kennedy and Foreign Aid, p. 91.

"'R.D. Mckinlay and A. Mughan, Aid and Arms in the Third World ( New York: St. Martin's Rress, 1984), p.34.

${ }^{25}$ Packenham, Liberal America, p.60.

${ }^{26}$ Packenham, Liberal America, p.62.

${ }^{27}$ Packenham, Liberal America, p.62. 
intervention. ${ }^{28}$ Also, growing wealth offered a greater opportunity for trade and investment. ${ }^{29}$

During Johnson's Presidency, the priorities of the aid program differed in two aspects. Like the Kennedy administration, AID pursued the same goals: self-help, the coordination of aid programs within a state to receive the maximum benefit, incentives for private investment, and loans rather than grants. ${ }^{30}$ However, Johnson was willing to use the withdrawal of aid as a stick to threaten those states which pursued policies counter to U.S. interests. ${ }^{31}$

The second difference was in Congress' growing interest in political development issues. With the Title IX amendment to the Foreign Assistance Act, Congress specifically charged AID with strengthening organizations such as labor unions, community action groups, and other voluntary organizations, and involving them in development projects. It was an attempt to use aid to build "democratic institutions," or in other words, to use foreign aid to influence internal politics in terms of promoting power redistribution and democratic development. ${ }^{32}$ However, it

28 Joan Nelson, Aid, Influence and Foreign Policy (New York: The Macmillan Company, 1968), p. 13 .

${ }^{29}$ Aid, Influence and Foreign Policy, p.13.

${ }^{30}$ Packenham, Liberal America, p. 86.

31 Packenham, Liberal America, p. 89.

32 Packenham, Liberal America, p.100. 
had very little effect on actual AID policy. ${ }^{33}$

The Nixon/Kissinger years emphasized disengaging the United states from foreign entanglements, in an effort to relinquish the roles which were perceived as detrimental to U.S. interests. The approach was pragmatic instead of ideological, and stressed the need to share burdens with other states. Economic aid was increasingly given through multilateral institutions. ${ }^{34}$ Military aid was used as a support and reward for allies, as in the case of Iran where the Shah was given a carte blanche for arms purchases.

Economic aid from AID had been increasingly given to Vietnam in support of displaced peasants and general support of military strategy. This continued until the U.S. negotiated its withdrawal from Vietnam, but it severely affected the AID program. As AID funds were used for war support in the name of development, a "credibility gap" emerged. In 1973, the Foreign Assistance Act was passed into law. AID as an agency remained intact; however, it was severely restricted by Congress, which required two detailed budgets per year and exercised a line-item veto over

${ }^{33}$ Packenham, Liberal America, p. 107.

31 James Howe and Robert Hunter, United states Aid Performance and Development Policy" in Aid Performance and Development in Western Countries: Studies in U.S.e U.K.. E.E.C. and Dutch Programs, (Ed.) Bruce Dinwald, (New York: Praeger, 1973) p60. 
expenditures. 35

The Foreign Assistance Act mandated a basic needs strategy, at the expense of developmental programs that involved a state-wide planning effort. Eberstadt charges that AID money was increasingly given to local leaders without any oversight, allowing them to use the money for whatever they wished. ${ }^{36}$ However, at the same time, the amount of aid money given bilaterally had already started to decrease. There was a realization, that U.S. aid had not achieved several of its goals, such as preventing communist takeover, promoting democracy, decreasing the gap between the less developed countries (LDCs) and the First world, or buying influence over the long term. ${ }^{37}$ Instead, economic development had created even greater discontent as societies mobilized with better health and more education, but no concomitant economic improvement for the majority of individuals.

After the 1973 oil price increases, developing states relied increasingly on private commercial banks to

${ }^{35}$ Nicholas Eberstadt, Foreign Aid and American Purpose (Washington, D.C.: American Enterprise Institute for Public Policy Research, 1988), pp. 34-36.

36 Nicholas Eberstadt, Foreign Aid and American Purpose (Washington, D.C.: American Enterprise Institute for Public Pollcy Research, 1988), pp. 38.

${ }^{31}$ James Howe and Robert Hunter, 'United States Ald Performance and Development Policy" in Ald Performance and Development in Western Countries studies in the U.S., U.K., E.E.C. and Dutch Programs edited by Bruce Dinwiddy (New York: Praeger Publishers, 1973), pp. 65-66. 
provide loans to cover deficits generated by high oil prices. ${ }^{31}$ It was also in response to a contraction in economic assistance by other governments in terms of development aid.39 The perception of U.S. banks and other investors was that governments were a good loan risk because it was impossible for them to default on loans in the accepted sense. States like the Philippines started took the initial steps towards a spiraling problem of borrowing more to finance larger debts, which would need to be financed by more borrowing. The world recession slowed down economic growth as developed states imported less, effecting the economies of less developed states. By the time of the second oil shock of 1979, the world had sustained several years of world economic recession. States were extremely reliant on forelgn loans, despite the reality of increasing interest payments, and extremely large debt amounts. 10

When the debt crisis became apparent 1982, the U.S. assisted in two ways. First, the Federal Reserve put a lot

3 Catherine Gwin, "The I.M.F. and the World Bank: Measures to Improve the system" in Uncertain Future: Commercial Banks and the Third World, edited by Richard Feinberg and Valeriana Kallab (New Brunswick: Overseas Development Council, 1984), p. 112 .

${ }^{39}$ Gwin, "The I.M.F. and the World Bank: Measures to Improve the System" in Uncertain Future: Commerclal Banks and the Third world, p. 89 .

10 Benjamin J. Cohen, "High Finance, High Politics" in Uncertain Future: Commercial Banks and the Third World, edited by Richard Felnberg and Valeriana Kallab (New Brunswick: Overseas Development Council, 1984), p. 112. 
of pressure on U.S. lenders to keep lending, in order to finance the already large debt. At the same time, governments were subject to austerity measures imposed by the lenders. Initially grateful for short term loan assistance, Latin American states in particular increasingly viewed austerity measures as the cause of "retarded development, increased unemployment, and declining living standards" as well as increased political instability. ${ }^{11}$

The other change was that large amounts of loans to finance these debts were to be made through the IMF. The United states used the IMF as a front. U.S. bilateral demands for domestic economic reform were increasingly met with hostility. The U.S. put strong pressure on the IMF to increase the amount of special Drawing Rights moneys available ${ }^{12}$. In February of 1983, SDRs went from 61 billion to 90 billion. The IMF, being a multilateral institution, could impose austerity measures without the political backlash and charges of interventionism that would be hurled at the United states by political opposition groups and governments within the recipient states. Cohen states that "Any effort to impose unpopular policy conditions on troubled debtors would undoubtedly have fanned the flames of

${ }^{41}$ Cohen, "High Politics, High Finance", p. 116.

12 Special Drawing Rights or SDRs are moneys available to lenders on a short-term basis when they have reached their limit of IMF funds available to them, but have a continuing need for money. 
nationalism, if not revolution, in many countries."13

ECONOMIC POLITICS/POLITICAL REALITIES

The transfer of large amounts of foreign aid from richer to poorer nations, is a relatively recent phenomenon. After World war II and the widespread and rapid decolonization of much of the world, it became evident that newborn states would not be able to attain economic growth either quickly or easily. In the 1950 s economists began to approach the problem of speeding up economic development, and the ways and means to accomplishing this end.

Walt Rostow was the first to create an economic theory of development, one in which forelgn aid occupied a specific function in developing economies. He made a number of important judgements about what "developed" and "underdeveloped" constituted in terms of the world economy as a whole." 4 These judgements informed the debates surrounding both political and economic relationships to the Third world. He created a yardstick by which to measure a state's position and progress. Governments in both donor and recipient states would need to intervene to insure a more rapid economic growth.

13 Cohen, "High Politics, High Finance", p.119.

11 Roger C. Riddell, Foreign Ald Reconsidered (Baltimore: The Johns Hopkins University Press, 1987) p. 87. 
Rostow identified developed states as those which had reached an "era of high mass consumption," achieved by going through a process of "take-off" into self-sustaining growth. Certain social and economic conditions needed to be created for "take-off" to occur. First, there must a significant increase in the rate of net investment; second, one of the manufacturing sectors must have a high growth rate; third, there must be an "institutionally favorable environment to ensure that the Impulses derived from growth are transmitted throughout the economy." 15

Underdeveloped countries could reach the "take-off" phase more quickly by infusions of two types of forelgn ald: capital in terms of equipment and supplies, and food and consumer goods allowing them to direct more of their own resources to development and away from consumption. of course, they would also require transfers of technical knowledge and skills. Rostow and fellow economist Max Milliken estimated in 1957 that states should only need this type of support from ten to fifteen years lalthough they offer no rationale for the choice of this time period). Rostow's work was attractive to policy makers because it fit so well within the short-term time frame of programs like the Marshall plan. The alm was to give a hand up, but not

15 The discussion that concludes this section relies on that of Roger Riddell in his book Forelgn Ald Reconsidered, pp. 88-92. It is the concise and yet comprehensive for those concerned with the economic theory behind foreign aid allocations. 
to become a substitute for autonomous economic growth.

Hollis Chenery and Alan strout were the next economic theorists to make a significant impact on development theory. They outlined preclsely how aid would work to accelerate growth in the underdeveloped economies - They specifled five preconditions for the creation of a developed economy: "an increase in human skills, a rise in the level of investment and saving, the adoption of more productive technology, changes in the composition of output and employment, and the development of new institutions."

However, in trying to achleve all these preconditions, states will face "bottlenecks;" specifically, shortages of skilis and organizational ability, constraints on achieving required levels of domestic saving and limits arising from inadequate supplies of imported commodities and services. These are characterized by two different gaps in domestic resources: investment-limited growth, where skills and savings are in short supply; and trade-11mited growth, where forelgn exchange is in short supply, because export earnings are lower than import needs. Foreign aid can help ease these bottlenecks by supplementing capital and savings, or import needs, or both.

It should be noted from the preceding outline that the term "development" took on a very specific meaning in these theories. It involved market economies with governments that made rational economic interventions based on adequate 
information about the state's economy. In 1 ine with Keynesian theory and practice, governments would intervene to alleviate problems of unemployment and recession. While not advocating socialist economics, these theories give an important role to states in managing their own economies. However, they ignored the nature of Third world governments in terms of the patrimonial orientation of Third World politics, and the effect of donor and recipient aid bureaucracies in the allocation of capital and technology.

\section{AID AND BUREAUCRATIC POLITICS}

Chenery and strout still provide the core theory to which reference is made, although there has been considerable debate and further work around their basic premise: that foreign ald, given certain conditions, can speed up development. 16 A more cautious approach was taken by Rosenstein-Rodan in 1961. While he emphasized a positive role for aid, he also pointed out that increases in production resulting from increased capital would not necessarily lead to an increase in savings. More available cash could also be put into consumption. Ultimately, the principal factor of development was not aid per se, but the citizens of a country." Rosenstein-Rodan advocated

\footnotetext{
16 Riddell, Foreign Aid Reconsidered, p. 92.

${ }^{17}$ Riddell, Foreign Aid Reconsidered p. 91 .
} 
organizational change along with demonstrated increase in savings as a criteria for aid donations. He believed that reciplent states needed to demonstrate an overall level of administrative and developmental organization that could adequately cope with aid disbursements in a macroeconomic perspective. ${ }^{48}$

However, Thlrd World governments do not use aid funds with the macroeconomic picture in mind. Ald can represent many goods for Third world bureaucrats and politiclans. The macroeconomic view of recipients is affected by a lack of data, uncertainties regarding the prices and quantities of commodities for export, and political uncertainty (coup d'etat, or other types of violent / unpredictable change). The major function of ald is perceived to be the reduction of these uncertainties. 19

In addition, the bureaucratic structure is such that the public sector budget may be dispersed by statutory boards or other local authorities controlled by the central government which may be unable to challenge them. For example, aid may be dispersed by farm boards or loan boards, which become autonomous and represent a single powerful interest group. 50 Mosley writes that "in most developing

${ }^{10}$ Riddell, Foreign Aid Reconsidered, p. 92.

${ }^{19}$ Paul Mosley, Foreign Aid, Its Defense and Reform (Lexington: The University Press of Kentucky, 1987) p. 89.

${ }^{50}$ Mosely, Foreign Aid, Its Defense and Reform, p. 90. 
countries a high proportion, often over half, of public expenditures are incurred by autonomous agencies and hence are not included within the central government budget".51 In other words, the process gets coopted by powerful elites. This is in direct conflict with Goldstone's picture of forelgn ald and its uses and 1 ts uses by a dictator who has become the conduit for foreign aid rewards.

More significant from a macroeconomic perspective is the non-centralized decision-making within the central government. The treasury department of a recipient state may not know what money the other ministries have spent or what aid contracts have been entered into for over a year. 52 Mosley claims that over fifty percent of recipient states do not have a central agency to monitor ald inflows and disbursements. 53 There is also a vertical fragmentation which occurs; several ministries may have to "sign-off" on an ald project before it will be approved. This leads to repetitive budgeting--aid amounts are recorded in several different budgets. 51

From a political power perspective, the ministers of recelving states are primarily concerned with receiving as much aid as possible, provided there are not too many

${ }^{51}$ Mosely, Foreign Aid Its Defense and Reform, p.91.

52 Mosely, Foreign Ald, Its Defense and Reform, p. 91.

${ }^{53}$ Mosely, Foreign Aid, Its Defense and Reform, p.91.

${ }^{54}$ Mosely, Foreign Aid, Its Defense and Reform, p.91. 
strings attached which constrain their freedom of action. Politicians have an interest in so far as it affects their sector or region. "How the money is spent may be critically affected by where the power lies," and who the individual politician seeks to reward. 55 Political patronage often determines the selection of beneficiarles. ${ }^{56}$ They also enjoy showy projects because it demonstrates that they are committed to modernizing the country. This holds true for both donor and reciplents. ${ }^{59}$ Aid can pay for services that constituents want, postpone price increases and loosen crippling foreign exchange constraints. ${ }^{58}$

Furthermore, civil servants enfoy the perks that aid provides, such as access to vehicles, air conditioning in the office, etc. ${ }^{59}$ Like any bureaucracy, different agencies want as much aid as they can get so they can become more important.

The important aspect of this description of bureaucratic and internal politics in recipient states is twofold. First, it shows that foreign aid is not always used in the ways in which it is intended at the outset by

${ }^{55}$ Desmond McNeill, The Contradictions of Forelgn Aid (London: Croom Helm Ltd., 1981) p. 91.

${ }^{56}$ McNeil1, The Contradictions of Foreign Aid, p. 68.

57 McNei11, The Contradictions of Foreign Aid, p. 55.

${ }^{58}$ Mosely, Forelgn Ald, Its Defense and Reform, p.93.

"Mcne111, The Contradictions of Forelgn Aid, p. 56 . 
donor states. There seems to be little evidence that donor bureaucracies allocate ald projects and monies with the stated intention of empowering entrenched recipient bureaucracies or enriching elite groups. In fact, the opposite would seem to be the goal; donor states have long urged recipient states to address inequalities in the distribution of wealth. However, the effect is much different. Those who have money or control over aid projects have power. They use that power to further their own interests, which frequently means staying in office and maintaining the status quo.

The second point involves leverage. Despite the fact that the United states or other bilateral donors may control the purse strings, recipient states do not passively receive money and let themselves be told what to do. The previous discussion of bureaucratic politics above mitigates the view that bllateral aid gives a donor state unlimited leverage in the affalrs of the recipient state. In terms of states like Iran and the Philippines, however, each leader played at bargaining for as much economic and military aid as possible, and gradually emphasized their assets in order to achleve greater leverage.

It will become evident, however, that both the shah and Marcos centralized power around themselves to a large degree, but their regimes were debilitated by corruption. In the sections analyzing the tenure periods in each state, it 
will become evident that the Philippines, much more than Iran relled on forelgn aid on a long-term basis. This did ennable the United states to assert more leverage, but not enough to make Marcos reform his corrupt government. 
CHAPTER I I

THE MARCOS TENURE PERIOD

This chapter outlines Philippine-U.S. relations prior to the Marcos presidency. The purpose is to help the reader understand the context of Philippine-U.S. relations when Marcos came to power. In addition, the history will demonstrate that the use of economic ald to keep philippine presidents who favored the U.S. in power did not originate with the Marcos regime. The U.S. forced many concessions from the Philippines that were important to its own security interests and business interests. What existed prior to the Marcos regime constituted a pattern of U.S. support for Philippine presidents; forelgn aid was used as a reward, and withholding promised aid was used as a threat and punishment.

EARLY U.S./ PHILIPPINE HISTORY

The history of U.S. involvement in the Philippines begins with Admiral Dewey's defeat of the Spanish in Manila Bay on May 1, 1898. There was an indigenous revolutionary group, led by Emilio Aguinaldo, which had fought the Spanish and was prepared to create a sovereign government. However, 
the United states sought colonization of the Philippines, and was awarded ownership by the Treaty of paris in December, 1898.60 Soon after Aguinaldo declared the Philippine Republic, fighting broke out between U.S. and Philippine forces. There followed a bloody two year war to suppress the revolutionary forces led by Aguinaldo, in which atrocities were committed by both parties.61 After his capture on March 23, 1901, the United states proceeded with a relatively benevolent and short-lived colonization.

In 1902, more than 400 school teachers (known as Thomasites because they arrived on the steamer Thomas) presaged a long process of education and public health work intertwined with a conscious effort to prepare Filipinos for self-rule; the goal was to introduce democracy to Asia and help the supposedly backward people. ${ }^{62}$ The model for proper government was the United states, with its democratic republic and separation of powers. However, opposition to colonization gained ground in the United states, which was always a philosophically reluctant colonizer. In 1935, the Philippine Commonwealth was established as a result of the

60 Daniel B. Schirmer and stephen $R$. Shalom, The Philippines Reader (Boston: South End Press, 1987), p. 6 .

61 A. James Gregor, Crisis in the Philippines (Washington, D.C.: Ethics and Public Policy Center, 1984) page 3 .

62 Frank H. Denton and Victoria villena-Denton, Filipino Views of America (Washington,D.C.: Asia Fellows Ltd.,1986), p. 20 . 
Tydings-Mcduffie Act, which determined that independence would occur in 1946. In the meantime, the Philippines was prepared for democracy, with a governmental system modelled on the United states.

World war II intervened in the decolonization process when the Japanese attacked Clark Air Base at the same time as the attack on Pearl Harbor. By May of 1942, the last U.S. forces in the Philippines had surrendered to the Japanese. The Japanese established a puppet Philippine republic, and many elite Filipinos collaborated with the Japanese ${ }^{63}$ This period also created the core of the Hukbalahap resistance movement, which was later labeled communist and was one of the targets of CIA intervention in the 1950s. As in the war for independence era, the elite was split between collaboration and resistance. Post war punishment of collaborators never amounted to much, simply because so many people in the post war government had collaborated, or had family members who had done so. Rigorous prosecution would have severely depleted the number of avallable and qualified politicians. 64

General Douglas Macarthur returned to liberate the

63 For a brief outline of elite collaboration and Huk resistance, see stephen $R$. Shalom, The United States and the Philippines (Philadelphia: Institute for the study of Human Issues,1981), p.1-3.

64 David Joel steinberg, Philippine Collaboration in World War II, (Ann Arbor: University of Michigan, 1967) as reproduced in Shirmer, The Philippines Reader, p.79. 
Philippines on october 20, 1944. The Philippines was devastated by the battle to defeat the Japanese, and Manila was second only to warsaw in terms of war damage. ${ }^{65}$ An estimated one million died while fighting with the U.S. against the Japanese. 66 The Philippines looked forward with confidence to American aid with the task of rebuilding their country.

\section{RECONSTRUCTION AND INDEPENDENCE}

The Philippines achieved independence on July 4, 1946. However, the transition from commonwealth to sovereign state was marked by profound Filipino frustration and disappointment. The cause concerned the small amount of U.S. economic aid given for purposes of reconstruction versus Filipino expectations, and the conditions attached to receiving it. The Rehabilitation Act which authorized the aid was signed by President Truman of April 30, 1946.

The legislation resulting from the hearings conducted by the U.S. House Committee on Insular Affairs resulted in $\$ 120$ milition to the Philippine government for the repair of roads, port and harbor facilities and other public property

${ }^{65}$ Robert Pringle, Indonesia and the Philippines (New York: Columbia University Press, 1980), p. 11 .

${ }^{66}$ Pringle, Indonesia and the Philippines, p. 11. 
and $\$ 100$ million worth of surplus U.S. property. ${ }^{67}$ The remainder of the funds provided was provided to individuals for the restoration of private property. ${ }^{6}$ Ultimately, $\$ 400$ million was paid to private individuals and businesses." The reasoning behind the relatively small amount of payment transferred to the Philippines was the belief that reconstruction would create investment opportunities for private U.S. capital ${ }^{10}$.

Towards this end, passage of the Rehabilitation Act was contingent on acceptance by the Philippine government of the Bell Trade Agreement. Briefly, the trade agreement tied the Philippine economy to the United states by establishing a system of preferential tariffs and amending the philippine Constitution to allow up to $100 \%$ ownership by U.S. firms of utilities and investment in exploitation of natural resources." This preferential treatment is referred to as "parity clause." 12 As well, the agreement provided for quotas of certain raw materials (sugar, cordage, coconut oil, rice, cigars, etc.) that could be sold to the United

67 stephen R. Shalom, The United states and the Philippines (Philadelphia: ISHI, 1981), p. 35 .

" Shalom, The United States and the Philippines, p.36.

${ }^{69}$ Shalom, The US and The Philippines, p. 36.

10 shalom, The United states and the Philippines, p. 39.

${ }^{11}$ Schirmer, The Philippines Reader, p. 87 .

12 schirmer, The Philippines Reader, p.87. 
states without duty until 1954.73 After that time, increasingly larger percentages of the allowable quota would be subject to duty." Also, it allowed unlimited importation of U.S. goods duty free into the Philippines for eight years, followed by only partial tariffs for twenty years. ${ }^{75}$

The State Department opposed trade preferences, arguing that the United states didn't need them to secure foreign markets, and would benefit more from a world wide system without discriminatory trade barriers. 16 Congress, on the other hand, responded to special interests, and sought tariffs and quotas to protect U.S. industries. 11 For the Philippines, the effect was to reestablish the sugar and other agricultural industries that comprised the elite power structure of Filipino society and political life, and both governments acknowledged that preferences would re-establish

${ }^{13}$ Summary of the Bell Trade Act, from Treaties of the and other International Agreements of the United states of America, 1776-1949 by Charles I . Bevans, compiler, (Dept. of state publication 8728, washington, DC: U.S. Government Printing office, 1974, vol 11) p7-18; as reproduced by Schirmer, The Philippines Reader, p 88 . 88.

11 As reproduced by Schirmer, The Philippines Reader, p

75 William Chapman, Inside the Philippine Revolution (New York: w.W. Norton \& Company, 1987), p. 38 .

${ }^{76}$ Shalom The US and the Philippines, p. 38.

77 Shalom The US and the Philippines, p. 40. 
the pre-war status quo." what is significant, however, is the degree of intervention and presence in the Philippine economy this allowed to United states investors, and the fact that the arrangement was the necessary price of independence.

The other important piece of post-war independence legislation involved military base agreements and military aid. Filipinos have strongly resented the bases as an infringement on Filipino sovereignty and their exlstence has created ongoing tension in the U.S.-Philippine relationship. Essentially the Roxas government acquiesced to the United States, leasing sixteen bases including Clark Air Base and Sublc Naval Base for a period of ninety-nine years in order to get U.S. military aid. ${ }^{19}$ U.S. military commanders had authority over any crime committed on the bases (except between Filipino citizens), and any crime committed off the bases between members of the U.S. armed forces or during the act of performing a military duty. While the condition of extraterritoriality was the same as that governing NATO allies in Western Europe (where U.S. forces were present), the base agreement also prohibited the Philippine government from granting any other state access to the bases or any

"Shalom The US and the Philippines, p. 44-45.

${ }^{79}$ Chapman, Inside the Philippine Revolution, p.40. 
other base rights without U.S. consent. ${ }^{80}$ As well, the United states was given the right to recruit filipinos for U.S. military service."

Military aid was viewed in 1947, with the first of the base agreements, as partial payment for base rights, by both the U.S. and Philippine governments. 12 The Philippines benefitted because the aid was primarily intended to strengthen internal security; this orientation fostered the creation of the Joint United states Military Advisory Group (JUSMAG). Besides provision of military training and assistance with planning, JUSMAG was specifically designed to occupy the field of military planning to the exclusion of all other states, and to support the political orientation of the Philippines toward the United states. 13 Yet the tacit acknowledgement that military aid was partial payment for the bases didn't lessen the fact of the overwhelming

80 "Military Bases: Agreement Between the United states and the Republic of the Philippines, March 14, 1947," in $A$ Decade of American Foreign Policy, Basic documents, 19411949 , printed as Sen. doc. 123, 81st Congress, 1st sess., 1950, pp. 869-81, as reproduced by shalom, The US and the Philippines, p. 62 .

11 Shalom The US and the Philippines, p. 62 .

12 Shalom The US and the Philippines, p. 64 .

${ }^{83}$ Adjutant General, War Department, to Commander-inChief, AFPAC, 9 October, 1946, p.2, enclosure 6 to U.S. Military mission to the Philippines, History of United states Military Advisory Group to Republic of the Philippines, vol. $1, \frac{1}{1}$ July 1946 to 30 June, 1947, unpublished, available at Fort McNair, Washington, D.C., as cited in Shalom the US and the Philippines, p. 66. 
military presence of another country, even if it was the U.S.

THE HUKBALAHAPS, U.S. INTERVENTION, GROWING NATIONALISM

The years following independence saw a considerable amount of CIA intervention into Filipino political iffe. The suppression of the Hukbalahaps (a.k.a. Huks) from 1948 through the Magsaysay presidency, who were viewed by the CIA as being communist insurgents, is one of the most visible instances of this intervention. In addition, the united states attempted to control the selection of candidates for Presidential office through the traditional Filipino method of buying political loyalty. Since all candidates were corrupt, it was really a matter of which one would prove to be the strongest U.S. supporter.

Ramon Magsaysay, first as defense minister under president Quirino, and then as President, was credited with defeating the Huks. In reality, he was advised by Edward Lansdale, a CIA station chief in the Philippines; he was ordered to the Philippines as an advisor on counterinsurgency techniques nominally with the joint U.S. MIlitary Advisory Group (JUSMAG). 14 Lansdale was actively involved in coordinating the Philippine Civil Affairs office, which sponsored propaganda campaigns against the 
Huks. ${ }^{85}$ He and Magsaysay were responsible for coordinating the campaign against the Huks, and shared a room together at JUSMAG headquarters. ${ }^{86}$ Lansdale was also instrumental in helping Magsaysay to attain the presidency; he introduced him to foreign correspondents and arranged for him to be honored both in New York city and washington, D.C. ${ }^{87}$ Lansdale arranged for $\$ 500,000$ in clandestine campaign funds to be funneled into the campaign coffers. ${ }^{88}$ Magsaysay frequently charged that the United states had lost confidence in Quirino, and that U.S. aid would be cut off if Quirino was re-elected. ${ }^{89}$

The Huks had not worked with the resistance forces coordinated by the United states during the Japanese occupation. Instead, they had been labelled a communist organization, because their military leaders were communist. Most of the rank and file were not. ${ }^{90}$ when the war was over, a concerted effort was made to hunt them down at the insistence of landlords who feared agrarian reform. ${ }^{91}$ For the Huks, the struggle against the Japanese and

${ }^{85}$ Shalom, The US and the Philippines, p. 78.

${ }^{86}$ Shalom, The US and the Philippines p. 77.

${ }^{87}$ Shalom The US and the Philippines, p. 88 .

${ }^{88}$ Shalom The US and the Philippines, p.88.

${ }^{89}$ Shalom The US and the Philippines p. 89.

${ }^{90}$ Chapman, Inside the Philippine Revolution, p. 58.

91 Chapman, Inside the Philippine Revolution, p. 61 . 
collaborationist landlords was now directed against exploitative landlords. 92 The Philippines was experiencing a new type of agriculture, which was profit oriented. This meant that instead of the old paternalism, peasants received a smaller part of the harvest, without the reciprocal obligations that characterized the pre world war II haciendero system. 93 The rebellion sputtered and died from a combination of effective military action by a revitalized Filipino military led by Magsaysay, fatigue on the part of the Hukbalahaps fighting since early in world War II, and because Magsaysay's modest reforms were what most conservative peasants wanted.91

Philippine land tenure patterns follow the haciendero system, reflecting 400 years of Spanish colonization. An oligarchy owned large plantations as the source of their wealth and formed the core families of the elite. oligarchs provided the money to bribe or buy the constituents for political candidates, and elected officials always discovered methods of preventing stringent land reform legislation. JUSMAG and CIA assistance in suppression of the Huks essentially ended any chance of power redistribution or alteration of the post-war status quo, because land tenure

92 Inside the Philippine Revolution, p. 64.

93 Peter Bacho, "Rural Revolt in the Philippines: Threats to stability?" in Journal of International Affairs winter/Spring 1987, Vol. 40, no. 2, p. 261 .

91 "Rural Revolt in the Philippines," p. 261. 
patterns and the control of wealth remained static.

The evolution of CIA involvement in the cholce of electoral candidates in the post-independence period stemmed from several pressures. The first came from the Huk rebelilion itself. Second, the philippines was a valuable bastion of democracy in an Asia that was either authoritarian (Republic of China) or communist (People's Republic of China).95 Third, concern for keeping the Philippines as a showcase for democracy led to concern over the incredible corruption of the both the Roxas and Quirino presidential regimes. 96 The amount of corruption in political life, coupled with the extreme inequities of income distribution, was recognized as a worrisome combination.

In addition to these problems, according to Daniel Bell (the state Department's leading expert on the philippines who led a special mission in June 1950), the state was facing financial collapse. 91 In order to receive additional economic assistance, however, the Quirino government agreed to reforms recommended by the Bell Mission, including an increase in tax receipts, a tax on the sale of foreign exchange, the enactment of a minimum wage law, land reform

95 Indonesia and the Philippines, p. 13.

96 Gabriel Kolko, Confronting the Third World (New York: Pantheon Books, 1986), p. 63 .

97 Shalom The US and the Philippines, p. 82 . 
and improving and reorganizing the public administration. 98 U.S. policy makers pressured Quirino to accept U.S. advisors, because they believed it would be "dissipated" otherwise. 99 The $\$ 250$ million package was bribe by the Truman administration to get Quirino to pursue reforms and accept U.S. advice and supervision. ${ }^{100}$

United states policy makers in 1951 were dismayed at the thought of Quirino winning in 1953, since he was considered an opportunist of the first order whose loyalty couldn't be determined with any degree of certainty. 101 Quirino's offer to withdraw in favor of Filipino ambassador to Washington, vincente Madrigal, on the condition that Madrigal's war damage claim would be paid off, "further estranged" U.S. policy makers. 102

Magsaysay was originally appointed as the Defense Minister in Quirino's cabinet, at the urging of American ambassador Myron M. Cowen. ${ }^{103}$ His speeches were written by the CIA ${ }^{101}$, which also played some dirty tricks on Quirino's

98 Shalom The US and the Philippines, p. 83, quoting from the Bell Report, pp. 1 (quote), 3-5, 59, 81, $95,101,105$.

"Shalom, The US and the Philippines p. 83 .

100 Shalom, The US and the Philippines

101 Shalom The US and the Philippines, p. 87.

102 Shalom The US and the Philippines, p. 87.

103 Shalom The US and the Philippines, p. 76.

101 Shalom The US and the Philippines, p. 76 . 
campaign such as doping the drinks of Quirino's speech makers. 105 Magsaysay's death on March 17,1957 was a blow for U.S. policy makers since no candidate was ever as completely devoted to U.S. interests or as manipulable.

One of Magsaysay's important achievements during office from the U.S. perspective involved the negotiation of the Laurel-Langley agreement, which replaced the Bell Trade Act on september 6, 1955. The new agreement extended parity to other industries besides raw materials and utilities, giving U.S. investors a much better path into the Philippine economy. 106 In order to placate the vocal nationalist opposition, parity was scrupulously extended to Filipino entrepreneurs, the tie-in of the peso to the dollar was eliminated, as well as absolute quotas except for sugar and cordage. 107 In addition, the agreement allowed each state to impose restrictions on the imports of products that harmed domestic production. 108

The two developments of the Garcia and Macapagal presidencies involved continuing corruption in politics, and growing nationalism from an emerging middle class and intelligentsia. James Burkholder Smith, a covert action

105 shalom The US and the Philippines, p. 91.

106 Shalom The US and the Philippines, p.97.

107 Shalom The US and the Philippines, pp.96-97.

108 Shalom The US and the Philippines p. 96-97. 
specialist with the CIA, was stationed in the Philippines during Garcia's presidency. He has written that

Garcia hadn't been in office six months before false bills of lading became standard at the Manila harbor, copra was being smuggled out of the southern islands in huge amounts, and a payoff system was put into effect for conducting any sort of transaction with the government ${ }^{105}$

In terms of growing nationalism, claro M. Recto, who ran as candidate in the 1957 presidential election, was one of the leading nationalists of this era. He advocated completely removing U.S. bases from filipino soil because they infringed on Filipino sovereignty and because they acted as magnets for foreign attack. 110 During the 1957 Philippine election, when Recto ran for President the CIA again played "dirty tricks" to prevent his election."1l

In terms of foreign aid and control and internal politics, foreign aid was used consciously as both a carrot and a stick prior to the Marcos presidency. The Trade Act is one example of this, but others include a promise by the Truman administration of $\$ 250$ million dollars of economic aid in exchange for Quirino's agreement to accept U.S. economic advisors, pursue tax reform and agree to pursue the reforms called for by the Bell mission.

109 James Burkholder Smith, Portrait of a Coldwarrior (New York: G.P. Putnam and Sons, 1976) as quoted in The Philippine Reader, p.149.

110 The Philippines Reader, p. 152.

111 Shalom The US and the Philippines, p. 104. 


\section{MARCOS REGIME PRIOR TO MARTIAL LAW}

Ferdinand Marcos was elected president on November 9, 1965. Former President Diosdado Macapagal, who owed his election to CIA support, had done little to combat corruption within the Philippine government. It was estimated in 1965 that one-third of all government revenues were consumed by corruption. ${ }^{112}$ As wel1, Macapagal had been supported because he advocated a continuation of the U.S.Philippines trade system. In return for lifting all exchange controls, Macapagal won $\$ 300 \mathrm{million}$ in U.S. and I.M.F. aid. ${ }^{113}$

The CIA reportedly stayed out of the 1965 election since both Macapagal and Marcos were pro-U.S. In 1966, however, soon after his election, Marcos pushed through a measure to send 20,000 engineering corps troops to vietnam, and authorization to allow the United states to use the military bases as logistic centers.114 In return, the Johnson administration, upon Marcos visit to washington, D.C. and President Johnson's return visit to the Philippines, responded with $\$ 38 \mathrm{million}$ in grants and an additional $\$ 39$ million for expenses incurred in sending

112 Confronting the Third World, p.187.

113 Kolko, Confronting the Third World, p. 187.

114 Kolko, Confronting the Third World, p. 188. 
Filipino troops to Vietnam. 115 "The Administration [Johnson] knew it would have to reward him with significant aid and that it would be channeled into Marcos's political coffers--perhaps even in his pocket."116

Marcos had run on a campaign slogan of "rice, roads and schoolhouses."117 prior to his election, the situation in the Philippines had deteriorated. Inequity in income distribution had increased, police protection was inadequate, and those who could afford to do so created private armies. 110 Freedom of expression had degenerated into "wild journalistic license and social anarchy began to threaten individual liberty." 119

Despite his campaign promises, Marcos did very little to amellorate the inequities in Philippine society. However, there were other forces creating difficult problems for Marcos, as for any leader. The Philippines was experiencing demographic changes which included population growth, a diminishing amount of land avallable to small farmers, and a trend toward the mechanization of farming. 120 As a result

115 Kolko, Confronting the Third World, p. 188 .
116 Kolko, Confronting the Third World, p. 188 .

117 Theodore Friend, "Marcos and the Philippines," Orbis, vol. 32, no. 4, Fall 1988, p. 571.

118 Frlend, "Marcos and the Philippines", p. 571.

119 Friend, "Marcos and the Philippines", p. 571.

120 Chapman, Inside the Philippine Revolution, p. 90. 
farm peasants no longer had the same value for hacienderos and many no longer had jobs. Migration to the cities occurred, and it is during the $1960 \mathrm{~s}$ that the squatter colonies first appeared, growing from 60,000 to 800,000 during that decade. 121

Also, a split had developed within the elite between those who wanted to continue to use political office for personal aggrandizement, and those who wished to pursue policies designed to sever ties with the United states and pursue more protectionist economic policles. The 1969 election which returned Marcos to power was violent and fraudulent 122 . To finance his campaign Marcos raided the national treasury to such an extent that it caused inflation ranging from 158 to 208 over the next three years. ${ }^{123}$ The United states also helped Marcos's reelection campaign, by allegedly allowing large sums paid to U.S. government employees in U.S. dollars to be sold at black market rates in Hong Kong. The money was then routed to Marcos, and it may have been as much as $\$ 200$ million. 124

However, Marcos' problems worsened in his new term.

121 Chapman, Inside the Philippines Revolution, p.90.

122 Chapman, Inside the Philippine Revolution, p.93.

123 Kolko, Confronting the Third World, p. 249-250.

124 w. Scott Thompson, "U.S. Role in the Philippine Transition," in Authoritarian Regimes in Transition, edited by Hans Binnendijk. Washington, D.C.: U.S. Department of state, Foreign service Institute, Center for the study of Foreign Affalrs, 1987. p.307. 
Late in 1969, the Movement for the Advancement of Nationalism (MAN) was created to help cure a "sick" Philippine society ${ }^{125}$. The middle class and landowners became increasingly fearful of communist rural revolution, despite the fact that the New People's Army (NPA), the military wing of the philippine communist party, had approximately 390 members in 1969, and dropped to 379 in 1971.126 However, Marcos expertly played on the fears of the middle class, and blaming agitation and rebelition on communist machinations. 121

In addition, from January to March, 1970, student protests known as the First Quarter storm commenced, serving as a focal point for widespread dissatisfaction. Philip Shabecoff, writing for the New York Times, reported that:

The oligarchy also is accused of using its political power to concentrate more of the national wealth into its own hands.

Almost daily, the Manila newspapers carry articles of scandals in which friends and relatives of Government officials are awarded huge Government contracts or loans for economically worthless projects.

Meanwhile, small farmers are unable to get loans for seed and fertilizer from their local rural banks because the Government does not have enough money to distribute to these banks.

Crime and violence have been getting out of control. Political murders are almost daily occurrences. Politicians and businessmen hire professional gunmen for protection. In the hills of Central Luzon, Communist insurgents and

125 Chapman, Inside the Philippine Revolution, p. 92.

126 Kolko, Confronting the Third World, p. 251.

127 Chapman, Inside the Philippine Revolution, p. 92. 

Government forces intended to 12 guell them outdo
each other in acts of terrorism.

In addition to these pressures, a Constitutional Convention was convened in 1971 to revise the country's constitution. Marcos had reportedly bribed several representatives to eliminate the amendment limiting the presidency to elght years, although it wasn't certain that there were enough votes to override the nationalist convention members. 129 Also, in August of 1972, the Philippine supreme Court issued two rulings, the Quasha and Lustevco decisions that were strongly against U.S. interests. Briefly, the Quasha decision held that U.S. ownership of private agricultural land had been illegal since 1946. The Lustevco decision decreed that firms in sectors of the economy reserved to Filipinos could not have foreigners as directors or management personnel. ${ }^{130}$ Gabriel Kolko writes that

It was clear now that Laurel-Langley would not be renewed when it expired in July 1974 and that U.S. investments with a book value of $\$ 640 \mathrm{mill}$ ion in 1979 (but a market value estjmated at three times that) would be jeopardized.

128 Philip Shabecoff, "Protest Movement in the Philippines Widening Rapidiy," New York Times, March 12, 1970, p.10.

129 Shalom, The Philippines Reader, p.164.

130 Shalom, The US and the Philippines, p.169.

131 Kolko, Confronting the Third World, p. 251. 
MARTIAL LAW

Martial law was publicly announced september 23, 1972. In the preceding months, several bombings had occurred around Manila. Marcos blamed communist subversives. On september 22nd, there was an unsuccessful assassination attempt upon the life of Defense Minister Juan Ponce Enrile. During the revolution Enrile revealed that the assassination attempt was engineered by Marcos as a pretext for declaring martial law. ${ }^{132}$

The stated goals of martial law were to create what Marcos termed the New soclety and to restore order. Marcos ostensibly sought to root out corruption, redistribute land, and break the power of the landed oligarchy that had controlled Philippine politics. However, by the end of martial law, the economy was in a worse position, and corruption was just as severe; the difference was that the corruption centered around the misuse and appropriation of funds by Marcos cronies, and by Marcos himself and his family.

Theodore Friend points out that opposition to martial law when martial law was first declared the reaction was "surprisingly light; real resistance was almost nil; 
unexpressed relief considerable."133 Marcos was successful in coopting members of the left such as Luis Taruc, a former Huk leader, and Blas ople, leftist labor leader. 131 Hundreds of thousands of weapons were confiscated, demonstrations and strikes were prohibited, and summary procedures were introduced to deal with street crime. 135 Marcos also attempted ambitious projects including road building, rural electrification, land reform and irrigation. 136

On the financial front, Marcos created a new c1ass of technocrats to manage the economy. While the Laurel-Langley expired in 1974, the Quasha and Lustevco decisions were overturned. Marcos opened up the economy to foreign investment to a considerable degree, and proceeded to implement policies that would change the orientation of the economy from import substitution to export-oriented growth. 137 Legislation was introduced opening commercial banks to foreign investment, guaranteeing the repatriation of capital, providing tax incentives, and easing entry

133 Friend, "Marcos and the Philippines" p. 572.

131 Friend, "Marcos and the Philippines, p. 572.

135 Friend, "Marcos and the Philippines, p. 572.

136 Friend, "Marcos and the Philippines, p. 572.

137 A.James Gregor, Crisis in the Philippines (washington, D.C.: Ethics and Public Policy Center, 1984), p. 39 . 
requirements for foreign capital and skills.138 As well, Marcos consolidated and assigned management of critical sectors of the economy to trusted loyalists, convinced that only cooperation and coordination between major sectors could help the Philippine economy. ${ }^{139}$

However, the reforms failed spectacularly. The external effects of the 1973 and 1979 oil shocks were devastating for the Philippine economy, which had begun to pursue an export oriented strategy. The world wide recession and subsequent debt crisis hit the Philippines hard. External debt went from $\$ 2.3$ billion in 1973 , to $\$ 3.8$ billion in 1975 , to $\$ 8.4$ billion in 1979.140 In addition, the Central Bank of the Philippines had misrepresented the amount of both its foreign exchange reserves, and understated the amount of the external debt of the Philippines to obtain new loans and credits. When pressed by foreign lenders in 1983 (a 90-day moratorium on payments had been requested because of alleged massive capital flight after the Aquino assassination) the external debt was reevaluated at $\$ 25$ billion. 111

The massive borrowing also was caused by the need of the Marcos government to save industries that had been

138 Gregor, Crisis in the Philippines, p. 40 .

139 Gregor, Crisis in the Philippines, p. 46 .

110 Kolko, Confronting the Third World, p. 257.

111 Frank Golay, "Cause for Concern in the Philippines" The Journal of Asian studies, vol. XLV, no. 5, p.940. 
monopolized by the government or that had experienced a high degree of government intervention, and which had suffered from the effects of crony capitalism. Frank Golay writes that

Inefficient enterprises managed by inexperienced entrepreneurs, men who were close to Marcos and interested in acquiring business experience, crowded out high-productivity activities. the cost of inefficiency and waste may be seen in the steady increase in the capital to output ratio in the Philippine economy. Increases in gross domestic product per capita in ASEAN countries other than the Philippines averaged 5.1 percent over the 1960s and 1970s, whereas the Philippine growth rate averaged only 2.8 percent. 112

There is convincing evidence of large scale corruption, which significantly impaired the economic program and ultimately support for the government. ${ }^{143}$

However, the amount of intervention was more extensive. An analysis done by economists from the University of the Philippines tabulated 688 Presidential Decrees and 283 Letters of Instruction which represented a form of government intervention in the economy. 14 Marcos issued exclusive rights to import, export, or exploit certain areas of activity; authority to collect large funds that were then privately expropriated; and preferential treatment of certain firms in an industry to extend new credit or to 938 .

142 Golay, "Cause for Concern in the Philippines," p.

143 Gregor, Crisis in the Philippines, p. 46.

141 Golay, Crisis in the Philippines, p. 938. 
restructure credit. 145

Martial law was officially lifted on January 17, 1981. However, Marcos kept most of the political power he had acquired under martial law. Liberal opposition leader Benigno Aquino, who had been imprisoned for most of the martial law period, had been given permission to travel to the United states for needed heart surgery. He returned in anticipation of the National Assembly elections scheduled for May 1984, hoping to unify the opposition. His assassination on August 21,1983, galvanized the Filipino populace. Two million people attended his funeral procession. ${ }^{116}$ Massive street demonstrations encompassed all socio-economic groups, and continued for a month afterwards.117 From that point on, Marcos came under increasing pressure from the United states regarding the abuses of his presidency.

145 Golay, Crisis in the Philippines, p. 938.

146 Friend, "Marcos and the Philippines,"

117 Claude Buss, cory Aquino and the People of the Philippines (Stanford:stanford Alumni Association, 1987), p. 16 . 
CHAPTER III

THE SHAH'S TENURE PERIOD

THE EARLY RELATIONSHIP

Unlike the Philippines, Iran had very little contact with the United states prior to world war II. A treaty regulating commerce and navigation between Persia (as it was referred to by the west) and the United states was signed in 1856. In the next century, two separate financial missions were dispatched in response to Persian requests for assistance with the management of state finances, first in 1911, and again in 1921. It was believed that the United states would not aggrandize itself at the expense of the country, unlike the British or Russians.148 The first mission, led by Morgan Schuster in 1911, was unable to make significant reform of the state's finances. To do this would have challenged powerful bureaucrats, the Persian elite, and Russian and British interests as well.149 The Russians

148 Yonah Alexander and Allan Nanes, editors, The United States and Iran A documentary History (Frederick: University Publications of America, 1980), p.1.

149 Barry Rubin, Paved with Good Intentions (New York: oxford University Press, 1980), p. 10 . 
successfully intrigued until schuster was dismissed. 150 The second mission, headed by an economic advisor with the state Department, Arthur Millspaugh, came to an end primarily because Millspaugh wasn't willing to compromise fiscal responsibility for Reza Shah's political ends. ${ }^{151}$

During world war II Iran found itself in the uncomfortable position of being occupied by three different foreign powers, the British, the Russians and the United states. The reasoning behind the August 1941 invasion rested on two facts: first, Iran provided the surest supply line for vital U.S. goods to reach the soviet Union. 152 Second, Iran possessed valuable oil fields, and production was controlled by the British. ${ }^{153}$ occupied zones were created, with the British in the south and the soviets in

150 Rubin, Paved with Good Intentions, p. 11.

151 This is my own conclusion based on reading correspondence from U.S. Ministers to Iran, Joseph Saul Kornfeld and Hoffman Philip, Charge d'affaires Wallace Smith Murray, and the memorandum of an interview between Minister Philip and Reza Shah Pahlavi (the father of the contemporary Shah), dated April 14 1927. Reza Shah, in a discussion of the matter with Minister Philip, complains that for all his good points, Millspaugh 's "disregard for the dignity of the government" was enough to obliterate all his good work. As cited in Alexander and Nanes, p.43 Despite the friction (which it appears was often the job of the state Department to smooth over), Millspaugh managed to considerably improve the finances of the state from 1921 to 1927 . He returned to Iran during the war to head a second financial mission; however, he was perceived as being in collusion with the British, and was unable to have the same success.

152 Rubin, Paved with Good Intentions, p. 18.

153 Rubin, Paced with Good Intentions, p. 18. 
the north. This arrangement mimicked the pre world war I era, when the British and the Russians had signed an agreement in 1907, carving the state into areas of influence. 151

Reza Shah was pressured into abdicating in favor of his son, Mohammed Pahlavi, who was only twenty when he assumed the throne. ${ }^{155}$ He had little real power, which suited the Allies, and the conduct of foreign and domestic affairs was "directly subjected to the dictates of the occupying forces."156 The Iranians appealed to the United states to assist them in attaining assurances from the British and Soviets that they would withdraw after the war had ended.157 Thanks to pressure from the United states, an agreement was signed by all three states in January of 1942, promising to withdraw not later than $s i x$ months after the end of the war. 158

However, the Soviets didn't leave on schedule, and continued to occupy northern Iran. shortly after the occupation in 1941, the soviets had closed their zone to free entry, and instituted a number of political and socio-

154 Rubin, Paved with Good Intentions, p. 19.

155 Amin Saikal, The Rise and Fall of the Shah (Princeton: Princeton University Press, 1980), p. 26.

156 saikal, The Rise and Fall of the Shah, p. 26.

159 Rubin, paved with Good Intentions, p. 19.

158 Rubin, paved with Good Intentions, p. 19. 
economic changes, including farming measures and reactivating the communist Tudeh party. ${ }^{159}$ It became increasingly clear that the soviets hoped to include Iran in their plans for post-war expansion. The United states had become increasingly aware of Iran's strategic importance during world war II, as a source of oil and strategic interest as a valuable regional ally against the soviet Union. 160 Cordell Hull, in correspondence with president Roosevelt dated August 16,1943 , wrote that

since this country has a vital interest in the fulfiliment of the principles of the Atlantic Charter and the establishment of foundations for a lasting peace throughout the world, it is to the advantage of the United states to exert itself to see that Iran's integrity and independence are maintained and that she becomes prosperous and stable. Likewise, from a more directly selfish point of view, it is to our interest that no great power be established on the Rersian Gulf opposite the important American petroleum development in Saudi Arabia. 161

The Soviets had also been seeking an oil concession from Iran, along with Great Britain and the United states, which the Iranian government, led by prime Minister sa'ed had

159 Saikal, The Rise and Fall of the Shah, p. 27. Although he doesn't go into a lot of detail, saikal does mention that certain estates were confiscated and then established as model farms with the help of the Red Army. Also, new regulations were created favoring the peasantry over landowners in crop-sharing, as well as the compulsory purchase or confiscation of large amounts of grain for government use.

160 Saikal, The Rise and Fall of the Shah, p. 30.

161 Alexander and Nanes, Iran a Documentary History, p. 104. 
refused to give to any of the occupying forces until after the war. 162 The soviets belleved that this refusal was a plot coordinated by the British and the United states. 163 Despite the Tehran Declaration of 1943, in which the British, the soviets and the United states had pledged to work together to preserve Iran's independence and unity as wartime allies, 164 the situation provided a preliminary skirmish between post-war rivals in the cold war which emerged after world War II. 165

A crisis was averted, but only with strong U.S. pressure as well as the maneuvering of Iranian Prime Minister Qavam. 166 on March 2, 1946, the soviets offered to partially withdraw the troops still stationed in northern Iran. 167 However, Americans in Iran observed reinforcements instead of withdrawals.168 The Iranians brought their protests to the security Council, and the United states, represented by secretary of state Byrnes, asserted that the United states would do everything possible to compel the

162 saikal, The Rise and Fall of the Shah, p. 31-32.

163 Saikal, The Rise and Fall of the Shah, p. 32.

164 Rubin, paved with Good Intentions, p. 23.

165 Rubin, Paved with Good Intentions, p.29.

166 Rubin, Paved with Good Intentions, p. 33.

167 Rubin, Paved with Good Intentions, p. 32.

168 Rubin, Paved with Good Intentions, p.33. 
Soviets to leave Iran. ${ }^{169}$ At the same time, Prime Minister Qavam seemingly gave in to soviet wishes, and negotiated an agreement whereby soviet troops would withdraw completely, and the Iranians agreed to the establishment of a joint Iranian-Soviet oil company, with the soviets receiving 518 ownership. ${ }^{170}$ However, the soviets agreed to approval of the agreement by the Iranian parliament, the Majlis.111 The Fourteenth Majlis had expired, and by its decree a new one couldn't be elected until all foreign troops had departed Iranian soil; this meant that the new Majlis would be considering the agreement after soviet troops had departed. 112 Unfortunately, the unrest in Azerbaijan continued along with further agitation by the communist Tudeh party, which had been considerably strengthened during the soviet occupation.

A memorandum of a conversation between the Iranian ambassador Hussein Ala and Dean Acheson, dated october 8, 1946, reflects that the situation had deteriorated from the Iranian perspective; elections had been called by Prime Minister Qavam at a time when it was likely that a large number of Tudeh deputies would be elected, and the

169 Richard Cottam, Nationalism in Iran (Pittsburgh: University of Pittsburgh Press, 1979), p.198.

170 Cottam, Nationalism in Iran, p. 198.

111 Cottam, Nationalism in Iran, p. 198.

112 Cottam, Nationalism in Iran, p. 198. 
ambassador felt that the state was in danger of soviet infiltration, evidently because Qavam had followed a policy of appeasement. ${ }^{113}$ The Iranians hesitated to send troops to reassert control in Azerbaijan Kurdistan because they feared a negative reaction by the Soviets. Prime Minister Qavam signed the order to send in troops on December 10, 1946. The resistance easily collapsed, because the soviets chose to abstain from any material support. 111 The Shah believed that this resulted from strong U.S. pressure, and the realization by the Soviet Union that the United States was not bluffing in its support of U.N. members threatened by aggression. 175

In an effort to cope with the difficulties in reunifying and regaining political control, the Iranians had requested more post-war aid, particularly to be included in the point Four aid program on the same footing as Greece and Turkey. These expectations were heightened by U.S. assistance during the soviet occupation after the war. ${ }^{176}$

173 Memorandum of Conversation, by the Chief of the Division of Middle Eastern and Indian Affairs (Minor) [Washington, ] October 8, 1946. Reproduced in The United states and Iran A Documentary History, edited by Alexander and Nanes, p. 180 .

174 The Ambassador in Iran (Allen) to the secretary of State, Tehran, December 17, 1946,2 p.m. as reproduced in Alexander, Iran A Documentary History, p. 188.

115 The Ambassador in Iran (Allen) to the secretary of state, Tehran, December $17,1946,2$ p.m. as reproduced in Alexander, Iran A Documentary History, p. 188.

176 Rubin, Eaved with good Intentions, p. 36 . 
However, the Truman administration calculated that aid should be restricted to token levels for two reasons. 177 First, Iran had a high degree of corruption and uncertain development plans, and it appeared unlikely that they would be unable to effectively use economic aid.178 second, the Iranian army did not have the training and the sophistication to absorb large amounts of military equipment, although the shah pressed for funding to create his own large-scale military deterrent. Instead, he ignored U.S. advisors, and seemed obsessed with military hardware. ${ }^{179}$ The principal threat to Iran, like the Philippines, was perceived by U.S. policy makers to be internal revolution. ${ }^{180}$ As well, Congress was reluctant to give more aid; after the corrupt kuomintang were defeated in China, the feeling was that it was better to demand performance in terms of reform first before giving aid.181

In addition to these considerations, the state Department was aware that many Iranians would resent the appearance of U.S. imperialism replacing British imperialism, and Iranian politicians feared to make an

171 Rubin, Paved with good Intentions, p. 39.

178 Ervand Abrahamin, Iran Between Two Revolutions, p. 251 .

179 Abrahamin, Iran Between Two Revolutions, p. 251,

180 Rubin, paved with Good Intentions, p. 38 .

181 Arahamian, Iran Between Two Revolutions, p.251. 
obvious alliance with either the U.S. or the U.S.S.R., preferring a traditional "balance" policy between the two superpowers. 182 While Iran was eventually included in point Four allocations in 1950, the amounts were very small amounting to $\$ 500,000$ for technical assistance ${ }^{183}$ as well as a \$25 milion loan from the Export-Import Bank. Richard Cottam has written that this policy actually benefitted the United states, because it argued against ability of Iran to manipulate the U.S. whenever confronted with cold war concerns were mentioned.184

\section{THE NATIONALIST MOVEMENT AND MOSSADEQ}

The nationalist movement and the era of Prime Minister Mossadeg must be seen interpreted against the background of oil concessions, and particularly the AIOC crisis. The

182 The Acting secretary of state (Lovett) to the Embassy in Iran, washington, January 3, 1948, 1 p.m. as reproduced in Alexander and Nanes Iran a Documentary History, p.189-191. The traditional "balance" policy refers to the Iranian strategy of playing one opponent off the other, which was the modus operandi in dealing with the British-Russian rivalry during the late 19 th and early 20 th centuries. Also, the Iranians emerged from the postcolonial period intensely distrustful of any influence by outside powers in internal Iranian affairs, since both the Russians and the British had actively engaged in intrigue to enhance their interests.

183 State Department Announcement of Point Four project in Iran october 19, 1950. Reproduced in Alexander and Nanes, Iran a Documentary History, p. 211-212.

184 Cottam, Nationalism in Iran, p.209. 
Anglo-Iranian oil Company (AIOC) maintained the concession on Iranian oil, allowing the British to refine and export it. This was a common arrangement for many of the oil rich states; they didn't possess the technology to refine their own crude, or have the necessary supply routes to transport it. However, the division of profits was a remnant from a quasi-colonial relationship and was extremely inequitable. The last agreement had been negotiated by Reza shah, and involved 208 of the dividends on ordinary shares, and four shillings for each ton sold or exported going to Iran.185 That agreement had been a considerable improvement over the previous one.

When the Iranians refused a soviet oil concession, they percelved it as a good time to renegotiate their agreement with AIOC as well, and pursued a 50/50 agreement 186 from which Aramco and the saudis had benefitted. ${ }^{189}$ The other demands, such as training more Iranians, and equal treatment by AIOC of Iranian and Royal Navy markets, were not unreasonable.188 However, the British refused the $50 / 50$ agreement, which angered the Iranians, particularly the committee in the Majlis appointed to consider the issue. 189

185 Cottam, Nationalism in Iran, p. 204.

186 Cottam, Nationalism in Iran, p. 204.

181 Rubin, paved with Good Intentions, p. 51.

188 Cottam, paved with Good Intentions, p. 204-205.

189 Saikal, The Rise and Fall of the Shah, p. 38 . 
The committee was led by Mohammed Mossadeq, who had consistently argued for greater control by Iran over its own resources.190 In response, his committee recommended nationalization, which further antagonized the British. 191

While the current prime minister, Ali Razmara, had attempted to persuade the Majlis that Iran could not run the industry on its own, he was assassinated March 7, 1951 by a nationalist religious group, which also threatened to assassinate the Shah. ${ }^{192}$ while some writers label Razmara as a "British stooge" in his attempts at conciliation, 193 others maintain that he was perceived to be supported by the United states as well, thanks to the actions of one member of the American embassy. 191 He was favored by the United states because he was perceived as a tough minded reformer, who was also wise enough to make a deal with the British to maintain the revenue the state needed. In any case, with his assassination, it was too late for the British to agree to the $50 / 50$ concession.

Mossadeg was elected as Premier in May of 1951, just after the Majlis completed passage of law nationalizing AIOC

190 Saikal, The Rise and Fall of the Shah, p. 37.

191 Saikal, The Rise and Fall of the Shah, p. 38.

192 Saikal, The Rise and Fall of the Shah, p. 38.

193 Abrahamian, Iran Between Two Revolutions, p. 206.

194 cottam, Nationalism in Iran, p. 209. 
(April 30, 1951). 195 This meant that the AIOC could no longer refine and distribute oil for its own profit. AIOC calculated that they could easily make up the short fall through their other concessions, and a world wide shortage of oil would probably prompt the United states to pressure Iran to conciliate. ${ }^{196}$ By the end of 1952, the British had withdrawn assets and advisors, had frozen conversion privileges from the Bank of England, and attained an agreement with other oil companies not to enter into any agreement with Iran replacing AIOC. ${ }^{197}$ Oil production dropped from 241.1 million barrels in 1950 to 10.6 million in 1952; the loss of revenue this entailed put a severe strain on Mossadeq's budget for promised economic reforms. 198 While sympathetic to Mossadeq's nationalist aspirations, United states policy makers also recognized the growing strength of the communist Tudeh party, which Mossadeq naively believed he could manipulate. ${ }^{199}$ By the time

195 Rubin paved with Good Intentions, p.51. The nationalization resulted in the well-known Anglo-Iranian 0 il Company Case, which was submitted to the International Court of Justice on May 26, 1951 by the United Kingdom on behalf of AIOC ( the British government owned $35 \%$ of the stock). However, the court declined the case on the grounds that Iran had not consented to its jurisdiction. Gerhard von Glahn, Law Among Nations (New York: Macmillan Publishing Company, 1986), p. 240 .
196 Rubin, paved with Good Intentions, p. 61.
197 Saikal, The Rise and Fall of the Shah, p.41.
198 Saikal, The Rise and Fall of the Shah, p.41.
199 Rubin, Paved with Good Intentions, p.60. 
the Majlis approved nationalization, 12,000 oil workers were on strike and the Tudeh party scheduled a May Day demonstration that turned out to be 30,000 strong. 200 Mossadeq was unable to compromise with the British, because despite the high cost, nationalization was an extremely popular action. His supporters might literally tear him to pieces, and he created aspirations and expectations that could not possibly be satisfied. 201 Neither could he rely on United states aid, although it had increased from $\$ 1.6$ million in 1951 , and to $\$ 23.4$ million in $1952 .{ }^{202}$ This was just enough to pay the military and civil service, but not enough to replace the lost oil revenue, in order to force Iran into some type of settlement. ${ }^{203}$

Relatively late in the crisis, as the United states played honest broker, the Truman administration had tried to orchestrate purchase of Iranian oil by U.S. companies. However, the Attorney General was in the midst of preparing a case which charged these same companies with violation of Sherman Anti-Trust regulations. The state Department tried to intervene, claiming that petroleum constituted a vital national security interest, and president Truman terminated the investigation, concluding that for all practical

200 Rubin, Paved with Good Intentions, p. 63.

201 Rubin, Paved with Good Intentions, p.61.

202 Rubin, Paved with Good Intentions, p.61.

203 Rubin, Paved with Good Intentions, p.62. 
purposes, oil operations were instruments of foreign policy in these states. However, time ran out for the Truman Administration, and it was unable to organize U.S. petroleum companies to break the blockade, and thus put pressure on the British. 204

Furthermore, the shah was actively plotting against Mossadeq, since Mossadeq believed in limiting his power, and anti-Mossadeq groups clustered around the monarchy. ${ }^{205}$ As the situation became polarized into pro- and anti- Mossadeq camps, the prime minister made two fateful decisions. In order to regain control of the military, around which support for the Shah converged, Mossadeq tried to assume the Shah's constitutional role of commander-in-chief, bypassing the Majlis, and declared emergency powers legitimized by a referendum. ${ }^{206}$ This brought Mossadeq into direct confrontation with conservative forces, and he alienated supporters with by taking dictatorial actions. ${ }^{207}$

Mossadeg's second miscalculation was in appealing to Eisenhower in a letter dated May 28, 1953. In the communication, he hinted that Iran could become pro-soviet, and might be ripe for soviet take-over if more aid was not

204 Rubin, paved with Good Intentions, pp. 74-75.

205 Saikal, The rise and Fall of the Shah, p43.

206 Saikal, The Rise and Fall of the Shah, p.43.

207 Saikal, The Rise and Fall of the Shah, p.44-45. 
extended to meet the economic crisis. ${ }^{208}$ Eisenhower refused to assist Mossadeg with more aid, recommending that he reach an agreement with the British. 209 In addition, the Tudeh seemed stronger than ever; a demonstration on July 21 , 1952, attracted between 50,000 and 100,000 demonstrators. 210 From the perspective of the United states, the Mossadeq regime had lost the ability to control the country, and Indeed seemed $x$ ipe for communist take-over. Mossadeg had made enemies among the conservatives, the royalists, and the parliamentarian groups. 211

The Eisenhower administration made its decision to take covert action on June 22, 1953. President Eisenhower's reply to Mossadeq's letter of May 28th, refused requests for more economic aid. ${ }^{212}$ The Shah was informed on August 1st by Kermit Roosevelt, the CIA operative in Iran, during a secret meeting, that the United states and Great Britain had decided to take covert action. ${ }^{213}$ The Shah agreed to leave the country after issuing two decrees that Mossadeg would

208 Exchange Between Prime Minister Mossadegh and President Eisenhower on the Oil Dispute and the Problem of United states Aid to Iran, letter from Dr. Mossadeq to President Eisenhower dated May 28, 1953, as reproduced in Alexander, Iran A Documentary History, p. 232-233.

209 Alexander, Iran A Documentary History, p. 233-234.

210 Cottam, Nationalism in Iran, p.225.

211 Rubin, Paved with Good Intentions, 78 .

212 Rubin, Paved with Good Intentions, $p 81$.

213 Rubin, Paved with Good Intentions, p. 82 . 
not comply with, one dismissing Mossadeg, and one replacing him with Fazlollah Zahedi. 211 Mossadeq arrested Colonel Nematollah Nasiri, when he attempted to deliver the shah's decrees, and proceeded to claim on August 16 via Tehran radio that the royalists had attempted a coup d'etat. 215 Tehran exploded with communist demonstrations, and the shah Eled to Italy in protest. 216 By August 18 , soldiers had started to demonstrate in the street in support of the shah, and gradually the tide turned against Mossadeq and the threat of a communist takeover. ${ }^{217}$ while the CIA had organized demonstrations to support the shah, they were much Iarger than anything the agency could have paid for, indicating an underlying support for the shah among the masses. 218 By August 19, Falzollah Zahedi was able to come out of hiding and assumed power.

The United states quickly moved to support the new regime; $\$ 900,000$ came from Kermit Roosevelt's safe, and Ambassador to Iran Loy Henderson promised to continue Point Four aid and to arrange a $\$ 45$ million emergency grant. 219 Mossadeg was arrested charged with treason, and imprisoned

214 Rubin, paved with Good Intentions, p. 82 .

215 Rubin, paved with Good Intentions, p.84.

216 Rubin, paved with Good Intentions, p.84.

217 Rubin, paved with Good Intentions, p.85.

218 Rubin, Paved with Good Intentions, p.87.

219 Rubin, paved with Good Intentions, p. 87. 
in solitary confinement for three years. 220

\section{CONSOLIDATION OF POWER}

The Shah depended on the United states for his regime's survival after Mossadeq's removal from power, and not surprisingly, Iran allied itself with the United states and the West against the soviet union. The shah moved to consolidate his power as quickly as possible, so that the Majlis couldn't limit the power of the crown. ${ }^{221}$ There were five groups in opposition to the shah: the Tudeh, the Nationalist Front (Mossadeq's party), the non-partisan intellectuals, including the bureaucrats and professional class, the organized clergy, and finally anti-monarchist tribes in southern Iran. ${ }^{222}$ The shah acted to outlaw the National Front in 1957; used martial law, military tribunals and a 1931 decree against collectivist ideology to crush the Tudeh; allowed provincial governors to use the gendarmerie to control elections to the Majlis and the senate; and finally created two parties, led by trusted courtiers, that were known colloquially as the "yes" and the "yes sir"

220 Saikal, The Rise and Fall of the Shah, p.45.

221 saikal, The Rise and Fall of the Shah, p.46.

222 saikal, The Rise and Fall of the Shah, p. 47. 
parties. 223 He then moved to have the Majlis which lessened the quorum needed to pass legislation, and allowing him to veto financial bills. 221

The intelligentsia and middle class were increasingly intimidated by S.A.V.A.K., the Shah's secret police. officially created in 1957, the organization benefitted from training by both the CIA and FBI, as well as Israeli intelligence. 225 Using infiltration techniques, it expanded its networks, created trade unions through the Labor ministry, and scrutinized anyone recruited into the university, large industrial plants, or the civil service. ${ }^{226}$ Its first leader, General Taimur Bakhtiar, became notorious for his brutality and corruption. The role of S.A.V.A.K. in Iranian society is hard to adequately describe; Richard Cottam, and expert on Iranian politics describes it as a $k$ ind of Gestapo, 227 and the degree to which it infiltrated Iranian society and the intelligentsia was formidable.

The psychological effect of the organization was perhaps the largest aspect of its power, because of the nature of the extended family in Iran. Every time someone 420 .

223 Abrahamian, Iran Between Two Revolutions, pp. 329-

221 Abrahamian, Iran Between Two Revolutions, p.420.

225 Abrahamian, Iran Between Two Revolutions, p.419.

226 Abrahamian, Iran Between Two Revolutions, p. 420 .

227 Cottam, Nationalism in Iran, p. 288 . 
was arrested and questioned and/or killed by S.A.V.A.K., it affected the entire extended family unit. ${ }^{228}$ This meant the organization was able to effectively influence many more individuals than the actual target, but that it also incurred the enmity of the entire family. S.A.V.A.K. punished those suspected of petty offenses as well as dissident activities, resulting in a kind of all pervasive terror in the general population. ${ }^{229}$ The organization frequently used brutal torture, and prisoners were often released only if they or their family promised to become informers. 230

The United states also supported the shah's regime. Between 1945 to 1952 , total grants and credits (this includes military as well as economic) to Iran were $\$ 29$ million, about half in loans. 231 In 1953, that amount jumped to $\$ 52$ million in grants, and reached $\$ 65$ million in grants in 1954.232 Along with the aid, the united states sent technical advisors, to assist with economic planning and the

\section{Rubin, Paved with Good Intentions, p.177. \\ 229 Rubin, Paved with Good Intentions, p.178. \\ 230 Rubin, Paved with Good Intentions, p. 177.}

231 U.S. Bureau of the Census, statistical Abstract of the United states 1960. (81st edition) Washington, D.C., 1960. p.872. Unless otherwise indicated, all dollar amounts are in dollars from that year.

232 Statistical Abstract of the US 1960, p.872. 
dispersal of economic aid. ${ }^{233}$ In terms of military assistance, three different groups were present: ARMISH, the United states advisory mission to the Iranian Army, GENMISH, the advisory mission to the Imperial Gendarmerie, and MAAG, the Military Assistance Advisory group. ${ }^{234}$ The Shah constantly pressed for higher and higher amounts of military aid, believing that Iran occupied a comparable position to Turkey in terms of strategic support for U.s. security. In 1953, a National Security Council memo admitted that

military aid to Iran has great political importance apart from its military impact. over the long term, the most effective instrument for maintaining Iran's orientation toward the west is the monarch, which in turn has the Army as its only real source of power. U.S. military aid serves to improve Army morale, cement Army loyalty to the shah, and thus consolidate the present regime and provide some assurance that Iran's current orjentation toward the west will be perpetuated. 235

However, it was the opinion of Eisenhower and Allen Dulles that Iran didn't need military expenditure and expansion at the expense of the economy. ${ }^{236}$ Their belief was that Iran could never develop a large enough army to repel a soviet

233 Saikal, The Rise and Fall of the shah, p.32.

234 Saikal, The Rise and Fall of the Shah, p. 54.

235 United States Policy toward Iran: A Report to the National Security Council by the N.S.C. Planning Board December 21, 1953, as reproduce by Alexander, Iran $A$ Documentary History, pp. 265-267.

236 Rubin, Paved with Good Intentions, 97. 
invasion, and shouldn't drain its resources in trying. ${ }^{237}$

The Shah was responding to regional instability, however, and he had a number of concerns. Egypt was embattled with Nasser at its helm, threatened by Britain, France, and Israel during the Suez Canal crisis in 1956. Irag suffered a coup d'etat in 1958, and subsequently withdrew from the Baghdad Pact. Syria and Egypt threatened Lebanon in 1958, and there were Nasserist attempts to overthrow king Hussein of Jordan. 238 These threats, combined with the imperatives of internal political struggle and the consolidation of his power, led the shah to increase the armed forces from 120,000 to over 200,000 between 1953 and 1963, and to raise the military budget from $\$ 80$ milition to $\$ 183$ million (at 1960 prices and exchange rates). ${ }^{239}$ The United states also increased its military and economic aid: in 1956, the United states gave $\$ 23$ million, in $1957 \$ 82.5$ million and in $1958 \$ 104.9$ million. 240 After the July 1958 coup in Irag, deliveries of promised aid were speeded up, and $\$ 28.6$ million of economic aid was converted for military purposes, and U.S. authorization was given to expand the

239 Rubin, Paved with Good Intentions, p.98.

238 Rubin, Paved with Good Intentions, p.98.

239 Abrahamian, Iran Between Two Revolutions, p. 420 .

210 Mark Gasiorowski, "Security relations between the United states and Iran, 1953-1978" in Neither East nor West edited by Nikki R. Keddie, and Mark Gasiorowski, (New Haven: Yale University Press, 1990), p.152. 
size of the Iranian army by 37,000 troops. 211

However, congressional hearings before the Foreign operations subcommittee in 1956 and 1957 found widespread corruption and mismanagement of aid funds. ${ }^{212}$ This combined with growing economic problems and dissatisfaction with the lack of democratic institution, and prompted U.S. policy makers to reduce military aid to Iran during Fiscal Year 1960, a decision which greatly angered the shah, who had been pressing for larger amounts of military aid. After the Kennedy administration came into office, it was decided that the emphasis would change from military to economic aid, 213 and this was consistent with the creation of the Agency for International Development (A.I.D.), the Peace Corps and the expanded Food for peace program, which were creations of the Kennedy administration.

\section{THE WHITE REVOLUTION}

To understand the Iranian-U.S. relationship during the 1960s, it is necessary to briefly discuss the shah's program for development and modernization, announced in 1963 as the White Revolution as opposed to red revolution because it

211 Gasiorowski, Neither East nor West, p. 152 .

212 Gasiorowski, Neither East nor West, p. 152.

213 Gasiorowski, Neither East nor West, p. 152. 
would be accomplished without bloodshed and violence, 244 or the alternative explanation is that it was distinguished from a communist red revolution. ${ }^{245}$ The importance of this reform program was the way in which it cemented a certain perception of the shah in the eyes of U.S. policy makers.

By the early 1960s, Iran was in the midst of an economic crisis. To implement an ambitious seven Year Plan for development, the state had resorted to deficit financing and heavy borrowing. ${ }^{246}$ A bad harvest in 1959-1960 aggravated the problem, and strikes increased, ending in bloody confrontations. 247 The Kennedy Administration responded by offering $\$ 85 \mathrm{million}$ in aid, on the condition that the shah bring 1 iberals into his cabinet and pursued meaningful land reform; the Kennedy administration also pressured the shah into naming Dr. 'Ali Amini as Prime Minister. Amini was a reform minded aristocrat, with allies among the National Front as well as the more traditional groups in the Majlis. Washington was familiar with him as the Iranian ambassador from 1955 to 1958, and as a negotiator in 1954 with the oil companies. In washington's perception he was able to make unpopular decisions, and he had a long-term commitment to

214 Saikal, The Rise and Fall of the Shah, p. 80.

245 Gary Sick, All Fall Down (New York: Random House, $1985)$, p. 10 .

246 Abrahamian, Iran Between Two Revolutions, p. 421.

247 Abrahamian, Iran Between Two Revolutions, p.422. 
land reform.

However, his tenure was brief; the National Front refused to support him because he would not disassemble S.A.V.A.K. ${ }^{248}$, and after he dismissed parliament he failed to schedule future elections in direct violation of the constitution. ${ }^{219}$ Also, the stringent fiscal reform measures forced on Iran by the United states and the IMF, which he implemented, made him very unpopular. ${ }^{250}$ Finally, the United states refused to support Amini when he clashed with the Shah over the need to cut the military budget. 251 Amini blamed the United states for not providing enough ald; however, the United states rejected this assertion, maintaining that aid levels averaged the same compared to the preceding four years. 252

of greater interest, perhaps, is that Amini's land reform policies involved redistribution of religious lands, or wagf lands which generate revenues primarily for charitable purposes, and Ruhollah Khomeini was an active protester against land redistribution. ${ }^{253}$ Khomeini began to openly protest in 1962, denouncing the Shah's regime for

248 Abrahamian, Iran Between Two Revolutions, p.423.

219 Cottam, Nationalism in Iran, p.303.

250 Abrahamin, Iran Between Two Revolutions, p. 424.

251 Abrahamian, Iran Between Two Revolutions, p.424.

252 Saikal, The Rise and Fall of the Shah, p. 77-78.

253 Rubin, Paved with Good Intentions, p. 109. 
living off corruption, rigging elections, violating the constitutional laws, stifling the press and the political parties, destroying the independence of the university, neglecting the economic needs of merchants workers peasant, undermining the country's Islamic beliefs, encouraging gharbzadegi---indiscriminate borrowing from the West---granting 'capitulations' to foreigners, selling oil to Israel, and constantly expanding the size of the central bureaucracies. ${ }^{25}$

He was arrested in June and held by S.A.V.A.K. for two months, and then was returned to the holy city of Qom, where he was held under house arrest. 255 He continued making speeches denouncing the Shah's dependence on the United states and denounced the power of the army as well as the U.S.-Iranian alliance. ${ }^{256}$ He was exiled to Turkey in 1964, and shortly thereafter went to lecture in theology in Iraq. ${ }^{257}$ Khomeini's arrest in June of 1963 sparked three days of rioting in Tehran, Qom, Isfahan, Shiraz, Mashad, and Tabriz, ${ }^{258}$ in which riot police killed at least hundreds and perhaps thousands. 259

The Shah was now free to announce his own white Revolution. Explanations of why the Shah decided at this time to pursue reform differ. Some authors, such as James

254 Abrahamian, Iran Between Two Revolutions, p. 425.

255 Rubin, Paved with Good Intentions, p. 111.

256 Rubin, Eaved with Good Intentions, p. 111.

257 Rubin, Paved with Good Intentions, p. 111.

258 Gary Sick, All Fall Down, p. 10.

259 Abrahamian, Iran Between Two Revolutions, p.426. 
Bill, argue that it was an attempt to create a traditional rural class to counter the urban middle class that refused to support the Shah. ${ }^{260}$ Ruhollah Ramazani has argued that the goal was to finally free internal decision making from the influence of external political influence through economic development. ${ }^{261}$ Amin salkal sees it as an attempt by the Shah to achieve two objectives: to widen his base of support through carefully controlled mass mobilization; this would have the effect of lessening his reliance on the United states, which would further strengthen his position. ${ }^{262}$ These are possible explanations, but what is also of interest is that from this period that the United states began to focus on the shah rather than other politicians or groups. The Shah consolidated his power and began to assume the image of a strong, independent, and decisive leader.

The White Revolution had six goals: comprehensive land reform; nationalization of forests and pastures; public sale of state owned factories to pay for the purchase of land for redistribution; workers' profit sharing in industry; the franchise for women; and the formation of the literacy

260 James A. Bill, "Modernization and Reform from Above: The Case of Iran" The Journal of Politics, vol. 32(1) February, 1970, pp. 19-40.

261 Ruhollah K. Ramazani, "Iran's 'White Revolution': A Study in Political Development" International Journal of Middle East Studies vol 5, 1974, pp. 124-139.

262 saikal, The Rise and Fall of the Shah, p. 80. 
corps. ${ }^{263}$ The Shah's referendum was considered a sign of popular support for his reforms: 998 of the voters endorsed the White Revolution program, but the percentage of the population that voted was only roughly $25 \% .261$

There were doubts within both the CIA and the Bureau of the Budget about the capacity of Iran to develop as rapidly as the white Revolution plan predicted; the infrastructure simply didn't exist to support the type of modernization envisaged. ${ }^{265}$ The Bureau of the Budget wrote a highly critical study of the white Revolution in 1963 that the inept application of land reform might lead to reduced farm production, and that without the necessary administrative and economic support, the shah would fail to make the peasantry into another support group for his regime. ${ }^{266}$ Under these circumstances, he would rely increasingly on the support of the military. ${ }^{267}$ Also, while the shah had made some progress by downsizing his army, easing his relationship with Moscow and providing greater benefits for urban workers, the CIA concluded that the shah would be disinclined to follow through on his reforms, since the

\footnotetext{
263 Saikal, The Rise and Fall of the Shah, p. 82.

261 Saikal, The Rise and Fall of the Shah, p. 82 .

265 Rubin, Eaved with Good Intentions, p. 112.

266 Rubin, Paved with Good Intentions, p. 112.

267 Rubin, Paved with Good Intentions, p.112.
} 
White Revolution was inadequately planned. ${ }^{268}$

The effect of land reform was successful in the sense that almost all large landholdings were eliminated, and the landlords' traditional power base, separating the shah from the rural population was eliminated. ${ }^{269}$ Also, former landlords did use their compensation to invest in industry as the Shah had hoped, 270 however there was still resentment at the loss of position by landlords including the clergy. 271 Educational and other reforms were impeded by red tape, and the overstaffed and inefficient bureaucracy. ${ }^{272}$ on the other hand, the creation of the Health and Literacy Corps, which went out into the country to promote both, mobilized educated youth into support of the shah and his goals. ${ }^{273}$ Also, provision of security benefits for industrial workers, such as the legislation of a minimum wage and social insurance policy, increased the shah's urban support where he had been traditionally weak. ${ }^{27 !}$

While the Shah mobilized large parts of the population, there was no concomitant avenue for political participation
268 Rubin, Paved with Good Intentions, p.112.
269 Saikal, The Rise and Fall of the Shah, p. 85.
270 Ramazani, Iran's white Revolution, p. 131.
211 Ramazani, Iran's White Revolution, p.134.
212 Ramazani, Iran's white Revolution, p. 132.
273 Saikal, The Rise and Fall of the Shah, p. 88 .
211 Saikal, The Rise and Fall of the Shah, p.87. 
created. 275 Land reform had ultimately failed, because the holdings of most of the beneficiaries were too small, and the government created state-run farm corporations in 1967 to alleviate the problem. 216 Also, there were 100 pholes in the land reform laws which allowed the royal family, among others, to keep large tracts of land, thus maintaining a traditional base of power. 217 The shah failed to institutionalize the gains he had made, since the Majlis continued as a rubber stamp organization, with two official political parties. Those groups, brought in to the Majlis, formed another source of support for the shah and political dissent was effectively suppressed by S.A.V.A.K. Traditional politics continued, with the shah at the center of a great web, refusing to build any institution that might weaken his power.

OIL REVENUES, MILITARY PURCHASES, AND THE APREARANCE OF ABSOLUTE CONTROL

Much of the Shah's increasing independence from the United states, and his ability to build a large army, can be attributed to the steady rise in oil revenues. official U.S. economic assistance to Iran was terminated in 1967, as
275 Abrahamian, Iran Between Two Revolutions, p.427.
276 Abrahamian, Iran Between Two Revolutions, P. 429.
297 Abrahamian, Iran Between Two Revolutions, p. 429. 
oil revenues continued to climb. oil income hit a record $\$ 555$ million in 1963-1964, and had increased to $\$ 958$ million in 1968-1969, $\$ 1.2$ bil1ion in 1970-1971, \$5 billion in 19731974, and nearly $\$ 20$ billion by 1976.278 Between 1974 and 1977, cumulative oil revenue topped $\$ 38$ bililon.

The combination of consolidation of power at home and increased oil revenues allowed the shah to look outward and begin to pursue the role of regional leader. He increasingly took policy positions that were not in perfect alignment with the United states, such as his state visit to Moscow in 1965, which garnered two economic and military agreements. 279 The first involved supplying the soviet Union with $\$ 600$ milion in natural gas, beginning in 1970 ; in exchange, the soviets agreed to build a steel mill in Isfahan, construct a pipeline from the caucasus to northern Iran, and build a machine tool plant in shiraz. 280 The second agreement garnered $\$ 110$ million dollars worth of armored troop carriers, trucks, and antiaircraft guns in return for natural gas from Iran. 281 The Shah also criticized the United states for food aid to Egypt, since Iran and Egypt had broken off diplomatic relations in 1960 , and Nasser had started supplying rebels in Khuzistan with

278 Abrahamian, Iran Between Two Revolutions, p.427.

279 Saikal, The Rise and Fall of the Shah, p.95.

280 Saikal, The Rise and Fall of the Shah, p.95.

281 saikal, The Rise and Fall of the Shah, p.95. 
weapons, in addition to troop maneuvers on Iraqi soil. 282

Another factor was the assessment by the state Department that it was important to supply allies with arms, since the soviet Union was already doing this for their allies. Despite the fact that in the assessment of the Defense Department's International Security Agency Iran was spending too much money on arms, the United states continued to supply Iran with sophisticated military equipment in order maintain the relationship. ${ }^{283}$

The so called two pillar policy that designated Iran and Saudi Arabia as regional security enforcers began during the Johnson administration. The United states was heavily involved in the vietnam war at the time the British withdrew from the Middle East, and was unwilling to undertake the burden of regional security. 284 It was unlikely that Arab states would trust another western power, certainly not one allied with Israel. 285 The saudi role was symbolic, while Iran provided the real strength. ${ }^{286}$ The shah wanted both superpowers out of the gulf, and believed that Iran should be able to protect its own interests by maintaining free

\footnotetext{
202 Rubin, Paved with Good Intentions, p. 117.

283 Rubin, Paved with Good Intentions, p. 119-120.

281 Rubin, Paved with Good Intentions, p. 125.

285 Rubin, Paved with Good Intentions, p.125.

286 Rubin, Paved with Good Intentions, 126.
} 
passage through the vital straight of Hormuz. ${ }^{287}$

After the 1972 meeting between Nixon, Kissinger and the Shah, military purchases reached new dimensions. In effect, Nixon designated the Shah as the regional power in the Middle East, in accordance with the Nixon Doctrine of disengagement. Towards the end goal of helping the shah maintain this position, the United states provided carte blanche on arms sales. 288 since the shah needed no prodding to purchase arms anyway, billions of dollars were spent on military equipment.

For the United states, a good relationship with Iran was crucial. The United states needed an advocate in OPEC and the Shah helped the United states to maintain a supply of oil despite the embargo of $1973^{269}$. Also, he supported Kissinger's shuttle diplomacy in the Middle East despite Arab criticism, and promoted an Arab-Israeli accord. 290 The other justification used for massive arms purchases in Iran was that it helped repatriate dollars into the U.S. economy which was severely affected and had slid into a recession along with the rest of the world. By 1970, the United states had become a net importer of oil, and supply from the Middle east was vital to the national economy as well as
207 Rubin, Paved with Good Intentions, p. 126.
288 Gary Sick, All Fall Down, p.15.
289 Rubin, Paved with Good Intentions, p.140.
290 Rubin, Paved with Good Intentions, p.140. 
national security.

It is difficult to comprehend the amount of arms that were purchased. In the first four years after the 1972 meeting, $\$ 9$ billion worth of equipment was ordered for delivery. Secretary of Defense James Schlesinger (under Nixon) attempted to introduce some restraint through two initiatives. First, he privately met with the shah on several occasions, arguing that Iran needed more trained personnel, not more sophisticated weaponry which the Iranians couldn't operate or service. ${ }^{291}$ second, he dispatched Richard Hallock, a highly regarded military procurement and management analyst and a former colleague at the Rand Corporation, to provide technical advice to the shah. ${ }^{292}$ Hallock's position was a delicate one, since he was to advise the shah as well as keep schlesinger informed of the Shah's views and problems as they occurred. ${ }^{293}$ since he was also independently on retainer as part of his own consulting company to the Government of Iran, Hallock ended up balancing three important sets of interests, and as time went on, questions were raised about his actions. 291 Ultimately, there was very little that schlesinger could do while kissinger remained in the white House. During the
291 Sick, All Fall Down, p.15.
292 Sick, All Fall Down, p.16.
293 Sick, All Fall Down, p.16
291 sick, All Fall Down, p16. 
course of his meetings with the shah, schlesinger tried to dissuade him, but his orders were to approve any item short of nuclear weaponry if the shah insisted. 295

While the scale indicates the Shah's monomania and the manner in which they were purchased indicates the extent to which he had centralized power around himself. Essentially, a very small group determined security expenditures and the military budget was exempt from audit procedures. ${ }^{296}$ The shah decided what he wanted, and the loans to purchase such items were automatically approved by the Shah's cabinet without receiving any information about the equipment itself.297 However, the U.S. Military Assistance Advisory Group (MAAG) believed that purchases were made without a consideration of long-term needs, were not synchronized with training and construction schedules, and that as a result, Iran was getting less value from its purchases than a better prepared state. 298

Despite the fantastic oil wealth, Iran was still a poor country. The shah stopped the rural investment program, and encouraged migration to the cities. Those who stayed in the countryside felt the shah did nothing for them, and those

295 Sick, A1l Fa11 Down, p15

296 Nicole Ball, Security and Economy in the Third world (Princeton: Princeton University Press, 1988), p. 55.

297 Ball, Security and Economy in the Third World, p. 55-56.

298 Ball, Security and Economy in Third World, p. 79. 
who went to the cities were unable to find jobs and 1 ived in slums. The average Iranian was quite poor, and his purchasing power was eroded by inflation, particularly for food. This kind of life was in direct contrast to the wealthy elite and the large number of U.S. advisors and technicians, who lived completely apart from Iranians in their own complexes. It was difficult for people not to believe that Americans were exploiting them, just as the Russians and the British had a century before. 
CHAPTER IV

TENURE COMPARISON

This chapter compares the tenure periods in each state. The comparison is divided into two parts. First, each state will be reviewed to determine how well Goldberg's framework fits the particular situation. The point is to determine how much influence the United states wielded over each leader, and whether U.S. influence, in terms of foreign aid, caused these leaders to become too dependent on the U.S. for foreign aid and over identified with the United states. Also, U.S. demands for actions as quid pro quo for foreign aid may have antagonized the nationalist feelings of opposition groups, making it difficult for them to maintain control.

Second, an assessment will be made of the other factors included for comparison, specifically the historical relationship with the United states, the amount of U.S. presence in the country and the role of religion in political life. These factors will be compared between the two states in order to evaluate their impact prior to the crisis period.

Before commencing the comparison and analysis, a review of Goldberg's framework may be helpful. Goldberg 
hypothesizes that Marcos and the shah both constitute examples of the neopatrimonial regime, which has certain characteristics. Chief among these is the centralization of power by the ruler, urban based support rather than mass popular support, and the presence of congresses and parliaments with little real power. Also, the leader acts as a power broker among four elite groups: traditional oligarchies, new professionals, the military and the bureaucracy. The neopatrimonial leader plays one group off of another to maintain power.

The neopatrimonial leader depends primarily on a system of patronage and coercion to maintain authority. The patronage system must be fueled, however, by monetary or prestige awards. Foreign aid solicited, won, and dispensed by the leader can provide the resources which are necessary to maintain his power. However, there are two costs for the dictator. First, leaders develop an overreliance on foreign aid at the expense of building mass political support. second, the United states may demand quid pro quos which irritate the nationalist feelings of elite and other groups. over identification can occur, and the leader can lose legitimacy, being perceived as a puppet or tool of the United states. Finaliy, if economic growth falters, he may not be able to provide fuel for the patronage machine which is his means of support. 
THE PHILIPPINES

Although the Philippines generally fits the framework very well, there are some discrepancies between it and the Philippines under Ferdinand Marcos. Also, the fit becomes much better after martial law was imposed in 1972, although again, there are some significant variations. Essentially, martial law provided Marcos with the opportunity to centralize power to a much greater degree; previously, he was constrained by the Congress, despite the fact that many could be bribed to his advantage. A demonstration of this restraint can be seen in Marcos' uneasiness regarding the Constitutional Convention. Although he spent a lot of money in trying to make sure that a provision limiting the president's term to eight years wouldn't be upheld, he could not be sure. The nationalist opposition was comprised of individuals (like Benigno Aquino) that were as wealthy and almost as powerful as he was. Undoubtedly, there were also convention members who were completely sincere in their beliefs in limiting presidential tenure and power, who couldn't be bought.

The four elite groups that Goldstone identifies--oligarchy, military, bureaucratic and new professional varied in strength. The military as a separate influential political entity didn't exist, and neither did the bureaucratic elite to a significant degree. The 
professional class was split between a newly expanded entrepreneurial group and the old liberal intelligentsia, comprised of the professional and entrepreneurial part of the traditional elite. The bureaucracy as a separate class Isn't discussed, although Marcos did fill it with people loyal to him. The real strength in philippine politics lay in the landed aristocracy. The reason for this is partly historical and partly cultural.

The spanish created an indigenous landed upper class during their colonization. This class was preserved when the United states became the colonizer. ${ }^{299}$ The CIA, in a National Intelligence survey report in 1965, observed that "the Philippines has traditionally been dominated by a small, wealthy elite, consisting of large landholders and a few powerful industrial and commercial entrepreneurs, and their lawyers." 300 Although the strength of the managerial and technical groups grew during the 1960's, they were unable to challenge the prevailing power structure controlled by the elite. ${ }^{301}$ The elite controlled extensive patron/client networks, which were reinforced by cultural practices.

299 Pringle, Indonesia and the Philippines, p. 8.

300 CIA, Philippines: General Survey, National Intelligence survey, NIS 99, July 1965 Isanitized copy released November 1980 J, pp. 48-54 reproduced by Schimer, The Philippines Reader, pp. 126-131.

301 CIA, General Survey, pp 48-54, as reproduced by Schirmer, The Philippines Reader, pp 126-131. 
What occurred after the imposition of martial law, however, was the selection of certain portions of the aristocracy to benefit from Marcos patronage. With the imposition of martial law there was no challenge to eliminating important families and their profits to enrich Marcos and his cronies, as well as his family. An example is Marcos management of the sugar industry. Growers were forced to sell through the National sugar Trading Company, managed by Bobby Benedicto, a former fraternity brother of Marcos at the Philippines Law School. 302 He was given authority to negotiate all contracts for purchase, milling and sale. ${ }^{303}$ Losses through financial and market manipulation by Benedicto have been estimated at between 11 billion pesos and 14 billion pesos (value of the peso ranged from seven to the dollar in 1981 to twenty in 1985). 304 This coincided with a world wide downturn in demand for sugar and the loss of the U.S. quota in 1974. ${ }^{305}$ The planters lost their easy lifestyle, and workers starved because mills closed; half the work force was on part-time, and one in Eive was unemployed. ${ }^{306}$ Planters also comprised a large group of the aristocracy which had no reason to love Marcos. While

302 Buss, Cory Aguino and the People, p. 53.

303 Claude Buss, Cory Aquino and the People, p. 53.

304 Claude Buss, Cory Aquino and the People, p. 54.

305 Buss, Cory Aquino and the People, p. 53.

306 Claude Buss, Cory Aquino and the People, p. 54. 
it can be argued that the downturn in demand would have had these effects whoever managed the industry, the extent of the impoverishment was likely due to corruption and mismanagemement by Bobby Benedicto.

The fact that Marcos assigned certain parts of the economy to friends and relatives was not shocking in itself, because there was an expectation that family would be provided for by the successful family member. This is a product of Filipino culture. They view the family and the extended kinship group as the "primary focus of an individual's loyalty," and this is equally true for maternal and paternal extended kinship groups. ${ }^{307}$ in addition, a system of ritual kinship called compadrazgo, is practiced. A non-kinsman godparent becomes a compadre by becoming the child's godparent at a baptism, confirmation or wedding. ${ }^{308}$ The relationship between the godparent and godchild involves reciprocal obligations similar to those between true kinsmen, and business or political alliances are routinely cemented in this fashion. ${ }^{309}$ The obligation, or "utang na loob," is not reciprocated in terms of a quid pro quo, but instead depends on the recipient's ability to

307 CIA, General Survey, p. 127 , as reproduced by Schirmer, The philippines Reader, pp. 126-131.

308 CIA, General Survey, pp. 127-128, as reproduced by Schirmer, The Philippines Reader, pp. 126-131.

309 CIA, General Survey, pp. 128, as reproduced by Schirmer, The Philippines Reader, pp. 126-131. 
return a favor according to his/her means. 310 This system of patronage relationships has spilled over into the political arena, so that politics in the Philippines was not unlike Tammany Hall days in the United states. ${ }^{311}$ The cIA report on Philippine political system stated that:

Like allegiance to kinsmen, allegiance to political leaders became dependent largely upon debts of gratitude arising from the ability and willingness of a leader to confer benefits upon his followers. Democracy, however, added a new element; the followers could discharge their debts of gratitude with their votes, along with those of whatever compadres, friends, of tenants they might in turn be able to influence. 312

Goldstone's assertion is that Marcos used the money and benefits to reinforce the clientelist relationship, and further develop the web of personal obligation that neopatrimonial leaders rely on. There is evidence that there was widespread official corruption prior to martial law. The documents from the symington hearings held in 1969 before Congress were sanitized, but it was clear that there was widespread crime and official corruption that Marcos was unable to control. ${ }^{313}$ There is also anecdotal evidence that

310 Frank H. Denton and Victoria Viliena-Denton, Filipino Views of America (Washington, D.C., 1986) p, 3031 .

311 CIA, General Survey, pp. 128 , as reproduced by Schirmer, The Philippines Reader, pp. 126-131.

312 CIA, General Survey, pp. 128, as reproduced by Schirmer, The Philippines Reader, pp. 126-131.

313 Raymond Bonner, waltzing with a Dictator (New York: Times Books, 1987), p. 73 . 
Marcos used official aid to enrich his friends prior to martial law. For example, four of the U.S. equipped engineering battalions provided to the Philippines as a result of the 1966 official visit to washington were used by Rudolfo Cuenca to execute a highway contract that Marcos had awarded to him. 314

During the martial law period, Marcos created his own technocratic class, and empowered his own close associates at the expense of the established professional class. In the process, he antagonized the traditional elite. Michael Armacost, former U.S. Ambassador to the Philippines, comments that "...one source of resentment against Marcos within the elite was the fact that by perpetuating himself in office for twenty years, he had denied many the chance to get up to the trough." 315 The President had extensive powers to influence the success or failure of any citizen or politician. 316 Unlike the situation in the United states, where being a Democrat during a Republican presidency does not personally affect an individual's success, business success in the Philippines is dependent on the correct

311 Bonner, Waltzing with a Dictator, p.53.

315 Michael H. Armacost, "philippine Aspirations for Democracy" in Authoritarian Regimes in Transition, edited by Hans Bennendijk. pp. 296-297.

316 CIA, General Survey, as reproduced by schirmer, The Philippines Reader, pp. 129 . 
political affiliation. 311 To support the liberal party when the Nacionalistas were in power meant taking a considerable risk. Martial law exacerbated the situation, giving Marcos a much wider control over the economy and thus the spoils system.

The military which the United states had participated in training through JUSMAG and the provision of military assistance was used to enforce martial law, and was responsible for the arrest and detention of thousand of Filipinos. When martial law was declared, soldiers detained between 60,000 and 75,000 , and reportedly engaged in kidnapping, torture and "salvaging." 318 The Armed Forces of the Philippines had to carry out and enforce all presidential orders and decrees during martial law. 319 U.S. aid to the military was construed to be support for martial law and its excesses. The range of repressive activities did not coincide with the threat as it actually existed; the New People's Army started to grow in the 1980's, as a response to martial law and the fact that there weren't any other avenues open for protest or dissent.

In the pre-martial law period, the Marcos regime

317 CIA, General Survey, as reproduced by schirmer, The Philippines Reader, pp. 129 .

318 Claude Buss, Cory Aquino and the People of the Philippines (Stanford:Stanford Alumni Association, 1987), p. 90. Salvaging means shooting a person in the head and dumping the body.

319 Buss, Cory Aquino and the People, p. 89. 
benefitted from substantial aid as a reward for allowing the Clark Air Field and Subic Naval Base to be used as logistics and supply . centers during the vietnam war. For example, after the 1966 state visit by President Marcos to the United states, the Philippines was promised $\$ 45$ million in economic assistance, $\$ 31$ million to settle veteran's claims, $\$ 3.5$ million for Imelda Marcos' cultural fund, and the previously mentioned engineering equipment for ten battalions. ${ }^{320}$ The Philippines continued to receive substantial amounts of military and financial assistance.

However, the biggest amounts came after martial law was declared. In 1973, the organization for Economic Cooperation and Development reported that net financial flows to the Philippines amounted to $\$ 97$ million dollars in 1972 and $\$ 112$ million in 1973, as opposed to a negative exchange $\$ 2$ million in 1971 , as capital flowed out of the country, back to the U.S. 321 Military assistance went from $\$ 18.5$ million in 1972 , to $\$ 45.3$ million in 1973.322

320 Bonner, Waltzing with a Dictator, p. 53.

321 Organization for Economic Co-operation and Development, Geographical Distribution of financial flows to Developing Countries (Paris: OECD, 1977), p. 186.

322 Figures are taken from reports from two government publications, "Military Assistance to the Govt. of the Philippines" and report submitted to the Fraser subcommittee by the Dept. of state in June, 1975 and "Foreign Assistance and Related Programs Appropriations, FY 1973" presented in hearings before the senate Appropriations Committee. They were reproduced by walden Bello in "The Logistics of Repression." 
Assistance continued at these levels through the early 1980s, when martial law ended, and it became clear that corruption was so rampant that it was destroying the economy. Since so much of the money came from the United states, the belief that the United states approved of martial law gained legitimacy for both government supporters and would be dissidents.

A staff report to the U.S. Senate Committee on Foreign Relations is perhaps the best indicator of the U.S. position towards martial law. submitted in 1973, the report discusses the attitude of Americans in the Philippines. They were generally supportive of martial law for three reasons. First, Marcos had promised to open the economy in ways which were very attractive to investors. Second, U.S. interests were not perceived to be related to the preservation of democratic processes. Third, the general opinion was that democratic process were considered to be deficient. However, there was also concern among "American officials" that martial law might lead a radicalization of the opposition since the only form of protest available would be violent protest. Also, the Nacionalista party already had a majority in both houses of the Philippine Congress, and therefore must bear responsibility for its ineffectiveness. However, what is most striking is the perception that the preservation of democracy was not coincidental with U.S. interests, and that the United states was pursuing a new 
pragmatism. ${ }^{323}$ Thus, while the United states did acquiesce to martial law conditions and provided considerable economic and military assistance, it was the absence of quid pro quos, in terms of reform, which dismayed the opposition rather than the increase in economic assistance.

As was evident from the previous chapter, the United states and the Philippines have a history of close ties after independence. Also, the amount of U.S. presence in the country is much larger than in Iran, from U.S. corporations to the Subic Naval Base and Clark Air Base. The bases alone employ approximately 15,000 workers, not counting dependents. 321 The presence of troops has provided employment, but Filipinos have always resented the sin cities which exist around the bases, Olongapo by Subic Naval Base, and Angeles by Clark Air Base. The important point here is that U.S. troops didn't come to the Philippines to make a profit but engaged in legitimate military activity allowed by the government. This presents a contrast to Iran, where thousands of Americans arrived to work at high paying technical jobs which the Iranians felt should have been theirs.

323 Staff Report prepared for the use of the U.S. Senate Committee on Foreign Relations, Korea and the Philippines: November 1972, committee Print, 93rd Congress, lst session, February 18, 1973, pp. 1-2, 4, 31-33, 37, 41, 45-6, reproduced by schirmer, The Philippines Reader.

321 Daniel M. Goldstein, U.S. Policy Concerning Renewal of the Military Base Agreement with the Philippines (Pittsburgh: Pew Charitable Trust, 1988), p. 15. 
Filipinos do not have a simplistic view of United states politics, or a monolithic view of Americans. Filipinos are accustomed to constant U.S. influence over their culture and society, and they do not perceive it as a malevolent one. ${ }^{325}$ For example, the expressions of concern in 1985 by the Senate Foreign Relations Committee were reported and well received at a time when many believed the U.S. was supporting the Marcos dictatorship. 326 This sophisticated view, particularly among urban intellectuals, may have prevented long-term bitterness against the United States. Also, Filipinos during the 1970s and 1980s were able to organize effective opposition groups in the United states, and they were also reportedly effective in appearing before Congress and the Senate Foreign Relations Committee.

In terms of religion, the Philippines is a predominantly Catholic country, except for Muslims in the south. The role of religion wasn't significant during the tenure period, except that some radicalization of the clergy did occur during the 1970s, particularly with the advent of Vatican II and the formulation of Liberation Theology. Philippine Catholicism had been conservative, concentrating on spiritual and not material conditions. The number of priests affected who joined guerrillas or organized their

325 Frank Denton and Victoria Villena-Denton, Filipino $\frac{\text { Views of America }}{1986 \text { ), p. } 188 \text {. Washington, D.C.: Asia Fellows Ltd., }}$ 326 Denton, Filipino Views of America, p. 189. 
own groups to indoctrinate the masses was never large, but it did split the church hierarchy in two different directions. This split is discussed in more detail during the analysis of the crisis period.

\section{IRAN}

Goldberg's framework doesn't fit Iran very well for several reasons. The most obvious is that from 1967 onward, Iran didn't receive economic aid from the United states, although it did host a Military Assistance Advisory Group, which attempted to assist the shah with planning and utilizing military purchases and training, and continued to receive small amounts of military aid. The tenure period should be divided into two phases: pre-1962 and post 1962 . Consolidation of the Shah's power occurred after he declared the White Revolution in July 1962, and it coincided with the acceleration of profits from oil production.

In the pre-1962 phase, the shah attempted to build up the military to reinforce his power. While he had taken decisive steps to crush the Tudeh party and considerably weaken the National front, he still was in danger of overthrow. The head of SAVAK, General Teimur Bakhtiar, was sent into exile in early 1961 for plotting a coup against him, which he had confessed to Kermit Roosevelt and Allen 
Dulles in 1958.327 His other source of support came from the landlords, bureaucrats and entrepreneurs which formed the upper class and the growing middle class. ${ }^{328}$ This led to problems such as the inability to tax the wealthy, landed aristocracy, since it was easier to raise taxes on staples for the working class. ${ }^{329}$ The United states extended considerable economic aid to pull Iran out of the economic abyss that AIOC crisis had caused, and had also continued to cover Iran's budget deficits, which inevitably maintained the status quo. ${ }^{330}$ By 1958, concern was growing about charges of corruption concerning the shah's family and increased repression. ${ }^{331}$ Sam Bowling, the Deputy Director of Greek, Turkish, and Iranian Affairs at the state Department, submitted a report to President Kennedy in 1961 which accurately predicted that traditional leaders, including the clergy, would provide dynamic leadership based on "the regeneration of Shi'a Islam," capture the urban middle class, and take over Iranian politics. 332 His

327 Rubin, Paved with Good Intentions, p. 108 .

328 Saikal, The Rise and Fall of the Shah, p. 71.

329 Rubin, Paved with Good Intentions, p. 101.

330 Rubin, Paved with Good Intentions, p. 100.

331 Rubin, Paved with Good Intentions, p. 101.

332 Political Characteristics of the Iranian Urban Middle-class and Implications Thereof for United states Policy: A report by the Deputy Director of Greek, Turkish, and Iranian Affairs (Bowling), United states Department of state to the President March 20, 1961, as reproduced by 
recommendations included "dumping his family, or most of it, in Europe," as well as reducing the military, making examples of corrupt ministers, and excoriating the traditional elite for its lack of social responsibility. ${ }^{333}$ However, without some type of crisis and further U.S. economic support, the shah would probably have been unable to announce the white Revolution.

The White Revolution's goals were admirable, and certainly impressed U.S. policy makers. However, the shah failed to broaden his base of support, and ultimately ended up by mobilizing the rural population into the cities. In fact, he entrenched the elite by allowing them investment opportunities supported by heavy state investment, as well as opportunities for court patronage. This failure can taken in the same context as other developing states, and the problem of rural migration without the robust economy to employ new groups, mixed with rapid population growth isn't unusual. Also, growth of an educated middle class, which is denied economic opportunity through the dominance of elite groups is the rule rather than the exception. The Shah used severe repression, however, and was genuinely out of touch with how dissatisfied people had become during the 1970s. He had concentrated on suppressing the intelligentsia, supporting the military and traditional elites, and had

Alexander, Iran A Documentary History, p. 322.

333 Abrahamian, Iran Between Two Revolutions, p. 328. 
taken the countryside for granted, believing that the benefits of land reform had permanently endeared him to the peasantry.

The composition of the elite groups was fairly static, however the salaried middle class which formed the civil service doubled between 1956 and 1977,331 and the military grew phenomenally as well. The traditional elite in Iran consisted of 1000 individuals only, who owned many of the large commercial farms as well as many of the private firms in banking, manufacturing, foreign trade, insurance and urban construction. 335 While the shah had succeeded in creating an educated middle class other than the urban merchants, bazaaris and clerics, he was unable to completely dominate the latter group, and in fact gravely antagonized them beginning in 1975. For the former group, he didn't create avenues for political participation, but instead used SAVAK to make sure they wouldn't become a threat to his regime.

The over identification of the Shah with the United states, again can be looked at using the pre-White Revolution phase and the post-White Revolution phase. The Iranian perception was that the United states re-installed the shah in 1953, and then provided him with both the economic and military wherewithal to consolidate his regime.

\footnotetext{
334 Abrahamian, Iran Between Two Revolutions, p. 434.

335 Abrahamian, Iran Between Two Revolutions, p. 432.
} 
The economy was subsidized through economic aid and SAVAK was trained and initially funded through military aid. This is an accurate perception and was consistent with the goals of United states economic and military assistance. However, what Iranians do not acknowledge as easily is that the demonstrations leading up to Mossadeq's removal could not have been completely generated by the CIA; there was support for the Shah, and probably for anything that would end the economic distress that Iran was in as a result of the AIOC crisis. Also, Iranians deeply distrusted the Soviet Union and Mossadeg's inability to control the soviet backed Tudeh party was frightening for many individuals.

In the post-White Revolution phase, however, the Shah was increasingly less reliant on U.S. economic and military support, and promoted Iran as a regional superpower in the 1970s, fully capable of bolstering United states interests while pursuing some rapprochement with the soviet Union. As well, Iran was a leader in OPEC, forcefully pursuing Iran's interests in terms of oll prices and assuring access to the straits of Hormuz. Yet the Iranians still associated the United states strongly with the Shah's regime, and believed that he was pursuing policies instigated by the white House. Part of this perception undoubtedly had to do with the massive arms sales which occurred in the 1970s. While some U.S. policy makers tried to impose restraint in terms of purchases, this information wasn't given to the public at 
large. Also, the presence of thousands of wealthy Americans, whose wealth was generated by the arms trade, caused heightened Iranian resentment against the United States at a time when many Iranians couldn't find employment. On the other side, the united states could only try to encourage the Shah to be more restrained; by the early 1970s, Iran's oil alone was vital as the U.S. shifted into dependence on foreign sources of oil. Also, U.S. policy makers had very little understanding of the real conditions of the majority of Iranians. The failures of intelligence and embassy personnel to gather information is documented in the following chapter on the crisis period. However, the cessation of A.I.D. assistance meant that there was no longer a group of U.S. personnel who were actively involved in trying to improve the lives of the average Iranian. There was a huge discrepancy between Iran's wealth from oil, and the state of the economy and the condition of people living in urban slums or rural poverty. Oil wealth was diverted into military spending, industrial and infrastructure investment and corruption. As in the Philippines, those that surrounded the leader benefitted monetarily as oil wealth was used to reward followers in a patronage network.

The final component of over identification involves Iranian culture and religion. First, there is a traditional national xenophobia which exists as a remnant of domination 
by the British and Russians in the late 19th and early 20 th centuries. The United states transgressed into interference in Iranian affairs with the re-installation of the shah. This meant. that for many Iranians the 1953 coup extended beyond their own memory; for them, U.S. behavior was, with few distinctions, analogous to British and Russian imperialism.

Second, Iran was and is a predominantly Muslim state, and Islam exists riveted to the perfect era when Mohammed lived in the seventh century after Christ. 336 Western values and customs were perceived with distrust, especially by religious leaders like Ayatollah Khomeini who advocated a return to an Islamic state. In Iranian tradition, as well as in the 1906 constitution, religious leaders are given authority to declare legislation void if it conflicts with Islamic principles. 337 Shi'a Islam differs from Sunni Islam in that there are certain principles set by one infallible imam and his descendants which are infallible. ${ }^{33}$ statements by religious leaders assume the importance of an infallible truth. The Ayatollah's judgements on the corruption of Western culture coincided with tremendous social and

336 Adda B. Bozeman, "Iran: U.S. Foreign Policy and the Tradition of Persian statecraft" in orbis, vol. 23, number 2 , summer 1979 , p. 387 .

337 Bozeman, "Iran: U.S. Foreign policy and the Tradition of Persian statecraft," p. 391.

338 Bozeman, "Iran: U.S. Foreign Policy and the Tradition of Persian statecraft," p. 390. 
economic change, which forced people to rely on traditional religion as a focus for their lives. For many, other roots such as village or occupation didn't exist any longer. Since the main Western presence in Iran was American, it is not surprising that the Ayatollah identified the United states and shah who was trying to modernize Iran, as the evil enemy. However, it took a decade of economic hardship, brutal repression by SAVAK and the persecution of the middle class before large numbers of students, outside of the religious schools would revolt. 
CHAPTER V

THE CRISIS PERIOD: HISTORY AND COMPARISON

The comparison of the crisis periods in the Philippines and Iran will focus on the U.S. response to regime failure and collapse. This chapter will document the crisis period in each state. The concluding section will explore the differences and similarities of the united states response to the devolution of power of President Marcos and the Shah, and the ascendancy of the new regime.

\section{THE IRANIAN CRISIS}

The revolution in Iran began with the riots in Qom on January 8, 1978, almost two years prior to the taking of the hostages on November 4, 1979. The factors which combined to cause the revolution had been present throughout the shah's regime, however, it was during the 1970 decade that the strains and stresses of heavy military spending, police state tactics used by SAVAK, and the mobilization of a growing middle class with no political outlet began to destabilize the country.

The Shah relied on the military to support his regime and to establish Iran as an independent leader in the Middle 
East. Given these two important roles, it is not surprising that so much money was spent in military purchases of sophisticated equipment and weaponry. The officer corps of the armed forces benefitted from attractive salaries, generous pensions, frequent travel abroad, modern medical facilities, comfortable housing, and low-priced department stores. ${ }^{339}$ Despite this preferential treatment, the shah purposely prevented the military becoming a threat to his own regime through several restrictions. The lines of authority were structured vertically, and the commanders of provincial military units had no direct contact with one another. ${ }^{310}$ Permission to travel to Tehran or meet with one another had to come from the Shah directly. ${ }^{11}$ Also, there were restrictions on the type of training allowed: exercises were limited to daylight hours, armed battalions could not travel more than $200 \mathrm{kilometers} \mathrm{per} \mathrm{year,} \mathrm{and} \mathrm{parade} \mathrm{ground}$ maneuvers rather than simulations were emphasized. ${ }^{312}$ These conditions can account for the M.A.A.G.'s understandable

339 Abrahamian, Iran Between Two Revolutions, p. 436.

310 Ann Schulz, "Military Expenditures and Economic Performance in Iran, 1950-1980: (Worcester, Mass.: Clark University, 1980, mimeograph), pp. 20-21 as quoted in Nicole Ball, security and Economy in the Third world (Princeton: Princeton University Press, 1988), p. 45.

311 Schulz, "Military Expenditures and Economic Performance," p 45 .

312 Schulz, "Military Expenditures and Economic Performance," p45, and Ball, security and Economy in the Third World, p. 45 . 
frustration at poor training and integration of the military, since part of the problem was created by the shah purposely.

In terms of the effect on the economy, military expenditures overwhelmed the Shah's budget, since he was also intent on pursuing ambitious goals in terms of modernizing the infrastructure and trying to build an industrial base. ${ }^{313}$ A lot of Iran's difficulties are blamed on excess military spending, however, the shah also pursued a policy of rapid industrialization, importing technical equipment and technicians. The rapid drive towards modernization made certain jobs obsolete, and people experlenced a profound dislocation as opportunities closed. ${ }^{34}$ Modernization was associated with the loss of jobs as well as the traditional way of life. ${ }^{345}$ The problem was exacerbated by unemployment, and the fact that the new jobs called for technically skilled labor, which was not available. Instead of a growing economy that could cope with a growing population, large groups lost ground. Wealth became more concentrated as the decade progressed.

The most prosperous Iranians, who made up 20 percent of the population, received 57.5 percent of

313 Saikal, The Rise and Fall of the Shah, p. 183.

344 An example is the use of plastic vessels to replace earthenware ones used for cooling. Once the source of livelihood for village potters, plastics made the profession obsolete. Rubin, Paved with Good Intentions, p. 268. 
the income in 1972 and 63.5 percent in 1975. The share of the middle 40 percent decreased from 31 percent to 25.5 percent over the same period, and that of the poorest 40 percent declined from 11.5 percent to 11 percent. 316

As traditional jobs were lost, people migrated to the cities which could not absorb them. The population of Tehran, for example, tripled in twenty years. 317 Also, although Iran's population doubled between 1962 and 1971, employment increased by only 23 percent. 318 The majority of the population was still illiterate, and untreated disease still caused major problems in rural areas. ${ }^{319}$ More than 75 percent of rural families subsisted on an income of $\$ 66$ per month and malnutrition was widespread. ${ }^{350}$ These socioeconomic ills were exacerbated by shortages and inflation. While the goals of reform were good public relations, the fact remains that sufficient investment in human capital did not exist to make them a reality.

Also, the purchases of military equipment did not translate into more jobs for Iranians. The equipment was so sophisticated that it required a highly skilled work force to maintain it which Iran did not possess. Instead, by 1976 there were 24,000 Americans 1 iving in Iran and without them,
316 Rubin, Paved with Good Intentions, p. 268 .
317 Rubin, Paved with Good Intentions, p. 268-269.
318 Rubin, Paved with Good Intentions, p. 143.
319 Saikal, The Rise and Fall of the Shah, p.186.
350 Rubin, paved with Good Intentions, p.143. 
the Iranian military would have been unable to function, since it could not maintain its own equipment. ${ }^{351}$ Although Iranians and Americans worked well together, there was still resentment because the American standard of living was so much better, and it was believed that they were taking jobs from Iranians. ${ }^{352}$ Most Americans lived in special subsidized housing, bought their goods at PXs, and sent their children to separate schools; despite their numbers, they made little impact on Iranian perception of Americans. ${ }^{353}$

While economic conditions worsened in the 1970s, repression by SAVAK also continued. The organization had grown to over 5,300 full time agents and an unknown number of informants, and it had the power "to censor the media, screen applicants for government jobs, and to use all means necessary to hunt down dissidents." 354 In addition to SAVAK, the Imperial Inspectorate kept SAVAK under surveillance, guarded against military conspiracies and reported on the Elnancial dealings of wealthy families. The J2 Bureau, which had been created in 1933 as part of the armed forces, collected military intelligence, but also kept an eye on

351 Rubin, Paved with Good Intentions, p.137.

352 Rubin, Paved with Good Intentions, p. 137.

353 Rubin, paved with Good Intentions, p.137.

354 Abrahamian, Iran Between Two Revolutions, p. 436. 
SAVAK and the Imperial Inspectorate. 355 while the Shah relied on SAVAK to maintain control, he was obviously distrustful of the organization, fearful that it might seize power for itself. SAVAK effectively created a climate where Iranians were hesitant to become involved in politics, because it could be dangerous for themselves or family members. ${ }^{356}$

In 1975, Amnesty International determined that Iran was a frequent violator of human rights, and this prompted hearings, and these reports prompted hearings before the U.S. Congress. By the following year, the subcommittee on Arms sales concluded that it was potentially dangerous to sell weapons to a regime that was so repressive. 357 In response, the Shah allowed some liberalization and curbed the worst instances of torture. Three hundred and fiftyseven political prisoners were amnestied in February, 1977, and in March the Shah allowed the International Commission of the Red Cross to visit twenty prisons. ${ }^{358}$ Iranian expert Richard Cottam reported in 1977 that the Shah was improving prison conditions. ${ }^{359}$ The state Department's

355 Abrahamian, Iran Between Two Revolutions, p. 436 437.

356 Saikal, The Rise and Fall of the Shah, p.190.

357 Abrahamian, Iran Between Two Revolutions, p. 500.

358 Abrahmian, Iran Between Two Revolutions, p. 501.

359 Rubin, Paved with Good Intentions, p.193. 
congressionally mandated report on human rights in 1977 was fairly uncritical, referring to terrorist activity and the pace of economic and social change to justify the repressive nature of the regime, while lauding Iran for the lower incidence of torture. 360

However, the Shah pursued policies from 1975 to 1976 that punished groups which had previously acquiesced to his controls. The middle class bazaar merchants, for example, suffered widespread intimidation and controls during the course of a campaign to end inflation and shortages officially blamed on profiteering. The government imposed strict price controls and imported large amounts of wheat, sugar and meat to undercut local businessmen. 361 The Guild Courts set up by SAVAK issued 250,000 fines, banned 23,000 traders from their home towns, sentenced approximately 8,000 shopkeepers to prison terms ranging from two months to three years, and brought further charges against 180,000 small businessmen. 362 This campaign was executed against a backdrop of corruption at court which was widely known. The court could depend on lucrative salaries, pensions, and monetary rewards, and investment opportunities for the Shah's family and associates abounded, as oil wealth was

360 Rubin, Paved with Good Intentions, p.194.

361 Abrahamian, Iran Between Two Revolutions, p. 498.

362 Abrahamian, Iran Between Two Revolutions, p. 498. 
diverted for personal gain. ${ }^{363}$ The Pahlavi Foundation, for example, received a $\$ 40$ million annual subsidy, and operated as a tax haven for some Pahlavi businesses. The New York Times reported that the Foundation "is used in three ways: as a source of funds for the royal family; as a means of exerting influence on key sectors of the economy; and as a conduit for rewards to supporters of the regime." 364

When Jimmy Carter was elected to the Presidency in 1976, his stand on human rights and opposition to arms sales encouraged the Iranian opposition to hope that the United states would put pressure on him to liberalize the regime. ${ }^{365}$ They grew bolder in calling for reforms, and openly circulated protest letters. ${ }^{366}$ The shah also believed that Carter expected him to liberalize, and he was reluctant to risk his relationship with Washington, because he still

363 Abrahamian, Iran Between Two Revolutions, p. 437. An example of this involves the shah's family borrowing money from the state banks at favorable terms, reaping the profits from investments. Also, it has been alleged that oil revenue --- as much as $\$ 2$ billion was transferred to secret foreign bank accounts. While the money transfers left no record in the state treasury, it did cause discrepancies between what oil companies paid for Iranian oil and what was documented by the government.

361 A. Chittenden, "Bankers Say Shah's Fortune Is Well above a Billion," New York Times, 10 January 1979. As quoted in Iran Between Two Revolutions, by Ervand Abrahmian (Princeton: Princeton University Press, 1982), p. 438.

365 Abrahamian, Iran Between Two Revolutions, p. 500.

366 Abrahamian, Iran Between Two Revolutions, p. 501- 
relied on washington as a source of arms. ${ }^{367}$ Beginning in 1977, the regime began to release political prisoners, and instituted court reforms promised to the International Commission of Jurists. ${ }^{368}$ The loosening of controls encouraged the opposition towards initially nonviolent protests; however, by November 1977, students were engaging in street demonstrations in Tehran. ${ }^{369}$

The revolutionary movement commenced with the riots in Qom at the beginning of the following year. Between six and one hundred demonstrators were killed in the January 9, 1978 riots, depending on which accounts are credited. The demonstration was in response to an article critical of the Ayatollah Khomeini which had appeared in the government controlled press, and came two months after the death of Khomeini's son, who was widely believed to have been killed by SAVAK. 370 This started off a cycle of protests following the shi'ite cycle of mourning which dictates a religious ceremony be held forty days after a death. ${ }^{311}$ on February 21st, riots broke out in Tabriz, where nine were killed and hundreds injured. The U.S. consul in Tabriz reported to Gary sick, assistant to National security advisor zbigniew

369 Abrahamian, Iran Between Two Revolutions, p.500.

368 Abrahamian, Iran Between Two Revolutions, p. 501.

369 Abrahmian, Iran Between Two Revolutions, p. 505.

370 Gary Sick, All Fall Down, p. 34.

371 Sick, All Fall Down, p. 35. 
Brzezinski, that the rioters were young, unemployed, and that the targets of the demonstrations had been symbols of western society such as social clubs and movie theaters. ${ }^{372}$ on March 29th, hundreds were arrested in Tabriz for rioting against the Shah and on May 11, demonstrations erupted in Tehran. ${ }^{373}$ on May 15, a general strike was called by religious leaders; however, troops patrolling the streets prevented rioting. 371

The Carter Administration's concerns at this time didn't concern the instability in Iran, but rather the appropriate actions to pursue given the conflicting imperatives reducing arms sales and the strategic importance of Iran for the United states. ${ }^{375}$ the debate centered around the Shah's latest arms request for F-4 aircraft, and whether they should be prepared for later insertion of sensitive radar equipment which had not been approved for export. ${ }^{376}$ Ultimately, the pre-wiring was not approved despite the Shah's insistent requests, and the debate was evidence that the days of the blank check policy were finished. 371 The Ambassador to Iran, James Sullivan, also travelled to

372 Sick, All Fall Down, p. 35.

373 Rubin, Paved with Good Intentions, p. 206.

371 Rubin, Paved with Good Intentions, p. 206.

375 Sick, All Fall Down, p. 45.

376 Sick, All Fall Down, p. 45.

377 Sick, All Fall Down, p. 45. 
Washington that summer where he met with Brzezinski. sullivan was preoccupied mostly with weapons sales to Iran which he favored, and was confident of the Shah's ability to deal with internal disturbances. ${ }^{378}$ Also, the demonstrations in June had been relatively peaceful, probably because of the intercession of Ayatollah Shariatmadari, who was often at odds with Khomeini's more extreme views. ${ }^{379}$ The timing of the demonstrations also lulled U.S. policy makers into a false sense of security regarding the seriousness of the demonstrations, and the Shah's ability to control them. The Shah would have understood the significance of demonstrations every 40 days, whereas U.S. policy makers would not.

The shah moved towards greater liberalization and political participation to calm the rioters. He chose August 5 , the beginning of Ramadan and Constitution Day, to promise reforms and free elections in 1979 which would include the opposition. 380 on August 11, however, widespread demonstrations occurred in Isfahan, Shiraz, Ahvaz and Tabriz. ${ }^{381}$ This was followed by a fire in a movie theater in Abadan on August 20, which killed 377 people, and rumors quickly spread that the fire had been started by SAVAK which

378 Sick, All Fall Down, p. 46.
379 Sick, All Fall Down, p. 47.
380 Sick, All Fall Down, p. 47.
381 Rubin, Eaved with Good Intentions, p. 206.


had locked the exit doors resulting in the death of women and children. ${ }^{382}$ The incident intensified government opposition, since most Iranians saw it as a premeditated massacre. ${ }^{383}$ Meanwhile, the Shah's government continued to pursue conciliation. The Shah appointed Jaafar SharifEmami as Prime Minister because he had a pious reputation, because he would be acceptable to the religious establishment, and it was believed that he would be more credible because of this background. 384 However, he was also elderly, ineffectual, and had been the head of the Phalavi Foundation which was the focus of suspicions regarding royal corruption. ${ }^{385}$ Sharif-Emami attempted to persuade Shariatmadari and other clerics to compromise, but they demanded that the 1906 constitution limiting the monarchy be returned, and that khomeini be allowed to come back into the country as conditions of reform. ${ }^{386}$ The Shah's government refused both conditions, and pressured Iraq to expel Khomeini, who subsequently settled in Paris, where he directed events by telephone, cassettes smuggled into Iran,

382 Rubin, Paved with Good Intentions, p. 207. The movie theater fire followed five other conflagrations in the twelve preceding days, which had been set by fundamentalists opposed to sinful movies.

383 Rubin, Paved with Good Intentions, p. 207.

381 Rubin, paved with Good Intentions, p.210.

385 Rubin, Paved with Good Intentions, p. 210 .

386 Rubin, Paved with Good Intentions, p. 213. 
messengers, and the international media. ${ }^{387}$

By september, the shah decided to pursue a crackdown policy, with the support of Brzezinski, whose views the Shah learned of via Iranian Ambassador Zahedi when he returned to Iran on september 5.388 on september 7 , between 700 and 2,000 people were gunned down during a previously announced demonstration in Tehran's Jaleh Square, on what is referred to as "Black Friday." 389 Carter telephoned the shah, expressing his regret at the violence and his continued support for the regime, while suggesting that liberalization should continue. 390 During the course of the conversation, the shah reiterated his commitment to liberalization and democracy, while restating his belief that the demonstrations were instigated by a small group that was taking advantage of liberalization. 391 Despite the evidence
387 Rubin, Paved with Good Intentions, p. 213.
388 Rubin, Paved with Good Intentions,
389 Rubin, Paved with Good Intentions, p. 214.
390 Rubin, Paved with Good Intentions, p. 214.

391 Sick, All Fall Down, p. 51-52. The Shah had no record of this conversation with President Carter. Why the Shah forgot the phone call completely is open to speculation; it may have been his illness. Gary sick believes that the shah was either in shock or under heavy medication. Ten days later, the Shah met with Ambassador Sullivan who reported that the shah was positive and determined, rather than depressed and indecisive. Sick believes that part of the reason why the crisis wasn't perceived as a threat was because rumors that the Shah was doing poorly mentally and physically were contradicted by Sullivan, and also because sullivan never said too much about the Shah's physical/mental health to Washington. 
that the demonstrations were increasing in number (as opposed to every 40 days within the traditional shia mourning cycle), the Carter Administration continued to support the shah, believing that he was trying to liberalize. However, the United states also attempted to remain aloof, refusing to intervene in internal political strife. Ironically, this did not convince Khomeini's followers of the detachment of the United states; the Ayatollah's mistrust of anything Western was too deeply ingrained to permit trust or compromise.

Also during "this time period the state Department and President Carter were deeply involved in other foreign policy issues. The president was in the midst of the meeting with Menachem Begin and Anwar Sadat at Camp David, and secretary of state Cyrus vance was deeply involved in SALT II. As a result, responsibility for handing the crisis came to Henry Precht at the state Department, Gary sick with the National security Council and Robert Murray at the Pentagon. None of the three allegedly possessed the experience or the authority to express their concerns to the President as their supervisors could. ${ }^{392}$ However, it was the Jaleh square incident that made at least Henry Precht realize that more than unrest was occurring, and that the 
regime faced a serious challenge. ${ }^{393}$ While the CIA kept reporting that the shah's army could handle the situation, the state Department believed that the critical issue in Iran was the shah's success or failure in convincing opposition leaders that the Shah wanted political reform and social justice. 391

By the end of september, strikes over wages and political issues were commonplace. ${ }^{395}$ There were buying panics, widespread hoarding, and wealthy Iranians had started to send their money out of the country. ${ }^{396}$ Prime Minister Sharif-Emami made concessions by closing theaters and gambling halls, conceding billions in wage settlements, promising a return to the Islamic calendar, permitting newspapers to be published without censors, proclaiming an amnesty which freed prisoners, and finally, by promising to allow khomeini into the country if he would moderate his position. 397 Also the Minister of the Court Amir Abbas Hoveyda was removed from his position, prior to a conviction for practicing corruption in the court and government. ${ }^{398}$ The Shah also allowed the switch of $\$ 200$ million from the

393 Rubin, Paved with Good Intentions, p. 215.

391 Rubin, Paved with Good Intentions, p. 216.

395 Rubin, Paved with Good Intentions, p. 217.

396 Rubin, Paved with Good Intentions, p. 218 .

397 Rubin, Paved with Good Intentions, p. 218 .

398 Rubin, Paved with Good Intentions, p. 218. 
military budget to pay for damage done by the riots and to compensate the families of those killed in the cinema fire. ${ }^{399}$ He reportedly engaged in a painful reordering of priorities which downgraded military spending and modernization. ${ }^{100}$ However, at the same time, he increased military salaries by 20 percent to ensure the loyalty of the armed forces. ${ }^{101}$ when these measures produced few results, the Shah pursued a more repressive course, with the support of Brzezinski conveyed by Ambassador Zahedi. 102

The pattern in the ensuing months was that of greater liberalization, followed by crackdowns when more violence occurred. The reason for the pattern is two-fold: first, the shah had alternately good and bad days --- in other words, like a lot of seriously ill people, his condition was unpredictable day to day, despite the fact that overall his health was failing. While these rumors reached Washington, embassy reports contradicted them on several occasions, so it was difficult for washington policy makers to get a clear picture of how serious the Shah's condition was. ${ }^{103}$ secondly, in retrospect, it seems obvious that incentives to compromise would have little effect on Khomeini, but there
399 Sick, All Fall Down, p.56.
100 Sick, All Fall Down, p. 56.
401 Sick, All Fall Down, p. 57.
102 Rubin, Paved with Good Intentions, p. 219.
403 Sick, All Fall Down, p. 53. 
wasn't any way for the shah to realize this at the time. For example, on october 26, 1978, the Shah granted amnesty to 1400 political prisoners, but five days later, Iran's oil workers went on strike. At that point, khomeini was the inspiration for the revolution which was acquiring further momentum. The Shah's actions were perceived to be erratic enough to cause doubts about his ability to govern. ${ }^{104}$ For example, while he expanded martial law to other cities, ordered the army to take over the major newspapers and pressured Iraq to deport Khomeini after Black Friday, he also amnestied political prisoners and arrested former government leaders for corruption. ${ }^{105}$ The speculation is whether this was a product of his illness, or simply bad crisis management; it seems evident, however, that the opposition wasn't responding to either carrots or sticks.

From October 6 onward, Khomeini was directing the anti-Shah movement from Paris, becoming the subject of television, radio and newspaper reports. 106 Khomeini advocated anything but a gradualist approach, and he warned National Front leaders that they would be ejected from the movement if they tried to negotiate with the shah. 107 The

\footnotetext{
104 Abrahamian, Iran Between Two Revolutions, p. 519.

105 Abrahamian, Iran Between Two Revolutions, pp. 518519.

106 Rubin, Paved with Good Intentions, p.220.

107 Rubin, Paved with Good Intentions, p. 222.
} 
U.S. had lost two opportunities to establish contact with the Khomeini opposition. Gary sick rejected Professor Richard Cottam's request to assist Khomeini to leave Iraq for Paris (Kuwait refused him entrance and Iraq wouldn't let him return) ${ }^{108}$, and the state Department refused to meet with Dr. Ibrahim Yazdi, a medical researcher working in Texas who claimed to be Khomeini's spokesman in the United states. ${ }^{109}$ It is difficult to say whether such a meeting, or timely assistance by the United states would have made any difference, but it would have established some good will at relatively little cost. At the end of october, the carter Administration was still giving strong assurances of support for the Shah, praising his efforts at liberalization, and proclaiming its confidence in the shah's ability to contain the ever growing violence and rebellion. 110

Finally in late october the policy debate began in earnest and more openly, with the completion of the state Department's report on Iran. The report's assessment of the situation was grim: essentially the shah had only a few weeks to establish legitimate leadership, or he would be

108 Sick, All Fall Down, p.57.

109 Sick, All Fall Down, p. 57. Barry Rubin alleges that the CIA also tried to speak with Khomeini in Paris, establishing headquarters in a house near Khomeini's in Nauphle-le-Chateau, a suburb of Paris. They only managed to contact Dr. Ibrahim Yazdi whose monologues consisted of explaining the Khomeinist's moderate stance. Rubin, Paved with Good Intentions, p. 220.

110 Rubin, paved with Good Intentions, p. 223. 
overthrown by the military. ${ }^{11}$ The report recommended that the United states follow a tripartite policy of support for the shah, continued support for liberalization (to the extent of advising the shah on domestic policy), while maintaining strong opposition to military rule. ${ }^{412}$ However, Ambassador sullivan rejected these suggestions, recommending that the United states follow the opposite policy of quiet diplomacy, and supporting the shah through his office, rather than with special envoys and advisors. 113

The situation in Iran deteriorated with the oil strike which began on october 31, reducing the production from 5.8 million barrels per day to 1.1 million. ${ }^{11}$ By the end of December, production would fall to 300,000 barrels per day, despite Iran's domestic consumption of 900,000 barrels per day. 115 Beginning on November 2, violent demonstrations and strikes affected the major cities in Iran, and in response, the Shah appointed General Gholam Reza Azhari as Prime Minister. 116 The speech with which the shah announced the appointment of the new Prime Minister was conciliatory in a strong contrast with his previous assessments, Ambassador
411 Sick, All Fall Down, p.59.
112 Sick, All Fall Down, p.59.
113 Sick, All Fall Down, p. 59.
114 Rubin, paved with Good Intentions, p. 366 .
115 Rubin, Paved with Good Intentions, 367.
116 Rubin, Paved with Good Intentions, p.366. 
Sullivan finally asked for instructions on November 2, intimating that the shah might not whether the crisis. 111 At the special Coordinating Council meeting later that day, it was decided, with secretary of state vance and president Carter's approval, to have Brzezinski instruct Ambassador Sullivan to express U.S. support for the Shah without reservation, whatever form of government he chose, and that once order was restored, the shah should continue with liberalization. ${ }^{118}$ Brzezinski also personally telephoned the Shah the following day to reiterate the message. 119

Gary sick, in his book All Fall Down, discusses the decisions by U.S. pollcy makers surrounding the fall of the Shah and the split between the National security Council, led by zbigniew Brzezinski, and the state Department, led by Cyrus vance. While vance initially disassociated himself from the decision-making surrounding the problems in Iran, it appears that he did so because he agreed with Brzezinski's position of continued support for the Shah. 120 It was left to his staffers, such as Henry Precht, to disagree with the National Security Advisor's decision to support the shah as the best leader as far as U.S. interests were concerned. Sick writes that Precht's position made it
411 Sick, All Fall Down, p.67.
418 Sick, All Fall Down, p.68.
119 Sick, All Fall Down, p. 68.
120 Sick, All Fall Down, p. 70. 
impossible for them to work together, since every phone conversation deteriorated into long laments about the incorrect course of policy towards Iran. 121 without vance's backing, however, Precht couldn't go very far. 122 The uncoordinated effort between the state Department and the NSC came at a time when each agency and the president were overburdened with resolving other difficult foreign policy problems. There was only one Policy Review Committee meeting during the entire crisis which was chaired by vance on November 6 ; at that time Vance and Brzezinski essentially agreed on a policy of continued support for the shah, and the need for better intelligence on the opposition. ${ }^{123}$

On November 5, Tehran exploded with coordinated attacks on Western symbols such as foreign banks, liquor stores, cinemas, Western business establishments, and tourist hotels. 121 The British embassy was invaded and the chancery was torched. 125 on November 6 , the Shah made a conciliatory speech acknowledging past abuses and promising reforms, while appointing General Gholamereza Azhari as Prime Minister to lead a military government. ${ }^{126}$ Azhari was

121 Sick, All Fall Down, p.70.

122 Sick, All Fall Down, p. 71.

123 Sick, All Fall Down, p. 77.

121 Sick, All Fall Down, p.74.

125 Sick, All Fall Down, p. 74.

126 Rubin, Paved with Good Intentions, p. 224. 
elderly and had a serious heart condition, but he also was a father figure for the armed forces, and there was concern because Khomeini was calling for the draftees to desert. ${ }^{127}$ This was a reality by the end of November, including soldiers as well as the homafars, technical experts who maintained the sophisticated equipment and who were capable of sabotaging it. 128 on November 7, the Ayatollah Khomeini, from his home in paris, declared that an Islamic Republic would be established with force if necessary. ${ }^{129}$

Finally, the embassy reacted to the accumulation of events which indicated that the shah was losing control. On November 9, Ambassador Sullivan sent his famous telegram, entitled "thinking the unthinkable," analyzing the position of the shah and other political forces. ${ }^{40}$ sullivan predicted that the military, which was comprised of Westernized officers, would reach an accommodation with Khomeini; the latter would need the military since it was crucial in controlling the country. ${ }^{131}$ This would force Khomeini to moderate, relegating him to a Ghandi-like position with a passive and benevolent influence in terms of

427 Rubin, Paved with Good Intentions, p. 224-226.

128 Many homafars had been held beyond their original contracts, and so had a legitimate grievance against the Shah. Rubin, Paved with Good Intentions, pp. 225-226.

129 Rubin, Eaved with Good Intentions, p.366.

130 Sick, All Fall Down, p. 81.

131 Sick, All Fall Down, p. 83-84. 
investing the new government with his blessing. 132 This scenario proved incorrect because it underestimated Khomeini's ability and the appeal of his message. sullivan's recommendations were not followed because there was no support by Brzezinski or Vance for supporting a moderate opposition at the expense of the Shah, and instead were interpreted as an attack on existing policy. ${ }^{133}$

Also in November, a note from President carter to Vance, Brzezinski, and CIA Director Admiral stansfield Turner was leaked to the press. ${ }^{134}$ In it President carter expressed his dissatisfaction with the intelligence reporting in Iran, and the issue quickly evolved into a general criticism of Turner and the CIA and forced a more general reappraisal of covert operations and intelligence. ${ }^{435}$ There were intelligence failures in Iran, and these came from the insular nature of embassy relations, as well as the restrictions which the Shah's suspicions placed on intelligence gathering. James Bill, an expert on Iranian politics, believes that the problem was the "incrustation" of the embassy. ${ }^{136}$ He writes that

132 Sick, All Fall Down, p. 83-84.

133 Sick, All Fall Down, p.86-87.

134 Sick, All Fall Down, p.90.

135 Sick, All Fall Down p. 90.

136 James Bill, as quoted in "Revolution in Iran" from Authoritarian Regimes in Transition edited by Hans Binnendijk (Washington D.C.: Foreign Service Institute, U.S. 
American officials knew all the same people. They were talking to the educated middle classes. No one was ever really in touch with religious leaders. Not many Americans were in touch with the students. Americans did not speak with any of the people that are now running the government in the Islamic Republic. They didn't see the present ruling group taking over; they didn't have contact with them.

The reason for this incrustation was the inability of most embassy personnel to speak Farsi, but also the all-pervasive presence of SAVAK. When contacts were made, it was difficult to know whether the individual was a SAVAK agent or not; ${ }^{138}$ the Shah actively discouraged embassy officials from making contacts with those who disagreed with the shah and his policies. ${ }^{139}$ Also, reports that differed from the prevailing perception that the Shah was fully in control were discounted, because they didn't correspond with assessments of the shah as the leader of the regional superpower of the Middle East. When the revolution finally did begin, it took months for policy makers to understand the seriousness of the opposition, the character of Khomeini, and to realize that the Shah was ill, indecisive, and unable maintain his regime. Even as the situation worsened in November, the embassy communications spent a lot

Department of state, 1989 ?), p. 11.

137 Bill, as quoted in "Revolution in Iran" from Authoritarian Regimes in Transition, p13-14.

138 Rubin, paved with Good Intentions, p. 181-182.

139 Henry precht, "Revolution in Iran" from Authoritarian Regimes in Transition, p. 10 . 
of effort in explaining the "distortions" of local news reporting in favor of official accounts.

Two special envoys went to Iran in late November to meet with the shah about the crisis: Treasury secretary Michael Blumenthal, and senate Majority Leader Robert Byrd. 140 Both found the shah indecisive and dispirited."11 on November 22, the National security Council hosted an all day meeting on Iran, at which all participants agreed that December would be the crucial month. 112 Khomeini had called for the people to arise and unite, despite the ban on demonstrations. 113 The question was how the shah would respond to continued unrest during a month of religious celebration (Moharam) which could easily evolve into political confrontation. 144

As demonstrations and strikes continued, the United states worked through a policy dispute between Brzezinski and Vance. While Brzezinski advocated a hard line approach of supporting the Shah, fearing that any appearance of abandoning the him would destabilize other alliances in the Middle East.115 George Ball, asked by Brzezinski to

140 Rubin, Paved with Good Intentions, p. 229.

41 Rubin, paved with Good Intentions, p. 229.

142 Sick, All Fall Down, p. 97.

143 Sick, All Fall Down, p. 105.

14 Sick, All Fall Down, p. 97.

115 Rubin, paved with Good Intentions, p. 235. 
undertake an analysis, disagreed with this assessment, perceived the shah as a weak and indecisive leader, and believed that the monarch should be encouraged to set up a regency council encompassing players from the different factions. 116 Ultimately, secretary of state vance and President Carter disagreed with both Ball and Brzezinski; in mid-December, Vance finally weighed in, stating his belief that the shah could not survive and that the best hope for the United states lay in supporting a prime minister chosen by the shah prior to his departure, which would be acceptable to the opposition as well as the Shah's supporters. 117 This became the official policy, even though Shapour Bakhtiar, the Shah's chosen successor, was expelled from the National Front party for cooperating with the Shah. 148

Despite the fact that Khomeini had dictated Bakhtiar's ouster from the National Front, President Carter made an overture to Khomeini in January to accept and support the Bakhtiar government. The first entailed a message asking Khomeini to support Bakhtiar in order to avoid bloodshed. 149 Khomeini replied that Carter must remove the Shah from Iran,
146 Rubin, Paved with Good Intentions, p. 236 .
117 Rubin, Paved with Good Intentions, p. 237.
418 Rubin, paved with Good Intentions, p. 238.
149 Rubin, Paved with Good Intentions, p. 240. 
and not support the Bakhtiar government. ${ }^{450}$ The second overture was an attempt to arrange a meeting between the Inspector General of the Foreign service Theodore Eliot and Khomeini; however, Brzezinski vetoed the plan even though the Shah had agreed to it, and it was proposed by vance and the President. ${ }^{151}$ Again, an opportunity for contact was lost due to a rigid policy of supporting the shah against the opposition, excluding any contact which would have given the appearance of lessening U.S. support for the monarch. In one sense, Brzezinski was right, but for the wrong reasons. It was unlikely that Khomeini would have been affected by meeting with Theodore Eliot, since his position was so extreme. Finally on January 16, 1979, the shah left for Egypt at the urging of the United states. He had been unable to arrange any compromise with Bakhtiar which would allow him even a limited exile. ${ }^{152}$ December had been a month full of violence, strikes, and continuing attacks on Americans. 153 This forced the Carter administration to finally support the Bakhtiar government at the expense of the Shah. The decision was taken during a National security Council meeting on January 3, 1989.454 General Robert Huyser was sent to Iran to

\footnotetext{
150 Rubin, Paved with Good Intentions, p. 240 .

151 Rubin, paved with Good Intentions, p. 240.

152 Abrahamian, Iran Between Two Revolutions, p. 524.

153 Abrahamian, Iran Between Two Revolutions, p. 524.

151 Sick, All Fall Down, p. 131.
} 
keep the Iranian military from either departing with the Shah or instituting a military coup, while the shah was informed by Ambassador sullivan, relaying a presidential memo, that he should leave the country for a long needed rest. ${ }^{455}$ After his departure, thousands demonstrated joyfully in the streets, unaware that Iran was entering into a new period of political instability. 156

The period between the shah's departure and the severance of diplomatic relations between the United states and Iran was one in which different opposition factions, primarily the moderate clerics and the National front party, vied for control with Khomeini's followers. Khomeini returned to Iran on January 31 , and it was apparent that he commanded the loyalty of most of the urban population as well as the rank and file military personnel, who were departing in large numbers. He had already named his own shadow cabinet in France, designating Mehdi Bazargan as Prime Minister. ${ }^{157}$ He was able to mobilize large numbers of individuals into demonstrations, strikes, and enforce the legitimacy of revolutionary tribunals; the latter had sentenced twenty-four individuals to death by March $5 .{ }^{458}$ By

155 Sick, All Fall Down, pp. 131-132.

156 Rubin, Paved with Good Intentions, p. 243.

457 Rubin, Paved with Good Intentions, p. 241.

158 Rubin, Paved with Good Intentions, p. 369. 
June, the executions totalled 300.499 After Khomeini announced that he supported National Front leader Mehdi Bazargan for Prime Minister, Bakhtiar's government lasted only until February 11, six days later. 460 It became apparent that real political power rested with khomeini, who was not content with compromise of any type. He sacrificed one Prime Minister after another after they became too moderate, all the time "restoring" the country to an Islamic model.

THE PHILIPPINE CRISIS

The Philippine Crisis began with the assassination of Benigno Aquino on August 23, 1983. Aquino was returning from the United states, where he had received treatment for a serious heart condition. His objective in returning to the Philippines was to unite the opposition groups in time to prepare for the legislative elections scheduled for May 14 as part of Marcos' liberalization after martial law. Only two months previously, Aquino had testified before Congress on the state of politics and repression in the philippines. In contrast to previous policy, Aquino's assassination marked the beginning of a more concerted effort to challenge
159
Rubin, Paved with Good Intentions, p. 370 .
Rubin, Paved With Good Intentions, p. 246 . 
the Marcos regime. 161

While the Nixon and Ford administrations had been mostly concerned with the maintenance of Clark Air Base and Subic Naval Base, president Carter had expressed more of a concern for human rights. 162 patricia Derian had made strong representations to the Marcos government, ${ }^{163}$ but the focus was on violations of personal integrity, such as torture. 164 By the 1980s, however, the NPA insurgency was growing and the economy was faltering as scandals of economic excess became more commonplace. ${ }^{465}$ When the United states protested against the treatment of prisoners to the Ministry of Defense, conditions were occasionally ameliorated, but had little real effect on the actions of the Marcos government. Also, Marcos and his wife Imelda were personal friends of the Reagan's, and some allege that this factor made President Reagan reluctant to acknowledge the damage Marcos

461 Theodore Friend, "Marcos and the Philippines" orbis Vol. 32, number 4, Fall, 1988, p. 578.

462 Friend, "Marcos and the Philippines," p. 576.

463 Friend, "Marcos and the Philipinnes," p.576.

164 Armacost, Michael H. "Philippine Aspirations for Democracy" in Authoritarian Regimes in Transition, (Ed) Hans Bennendijk (washington, D.C.: U.S. Department of state, Foreign Service Institute, Center for the study of Foreign Affairs, 1987) p297.

165 Armacost, "Philippine Aspirations," p. 298. 
was doing to the Philippines. 166

After the Aquino assassination, however, the United states embassy effectively pressured Marcos in three areas. The first objective was to get a prompt and complete investigation of the assassination; the second was to encourage more precise procedures for succession, since Marcos was seriously ill with a rare disease, lupus erythematosus; finally, the embassy urged Marcos to recognize the National Citizens Movement for Free Elections (NAMFREL) which had been created in the $1950 \mathrm{~s}$ by the United states. ${ }^{467}$ The embassy also urged Marcos to create a fair electoral code, and to promote a more independent commission on elections. ${ }^{468}$ There was only partial success: while NAMFREL was acknowledged, the commission on elections was not an independent body. ${ }^{469}$

The embassy and the ambassador, Michael Armacost, had come to the conclusion that the Aquino assassination could only have occurred with the connivance of someone close to the succession. ${ }^{\mathbf{1 7 0}}$ Marcos was aware that Aquino's assassination would make him a martyr; ergo, someone who

166 Raymond Bonner, Waltzing with a Dictator (New York: Times Books, 1987), p. 337 .

167 Armacost, "Philippine Aspirations," p. 300-301.

168 Armacost, "Philippine Aspirations," p. 301.

169 Armacost, "Philippine Aspirations," p. 301.

170 Armacost, "Philippine Aspirations," p. 299. 
wanted to get rid of Marcos was suspect. One theory is that along with General Ver, Imelda Marcos and her brother Kokoy Romualdez conspired to kill Aquino; Marcos was so ill at the time that his death seemed imminent, and Imelda Marcos wanted to rule the Philippines after his death. ${ }^{171}$ While Marcos blamed the assassination on communist insurgents, the embassy had been immediately sure that the Marcos government was involved. 172 six weeks after the assassination, President Reagan cancelled his planned visit to the Philippines, apparently because of negative domestic reaction to the assassination; however, he also went to some lengths to pacify Marcos by cancelling the rest of his itinerary and writing a personal note to the philippine president. ${ }^{173}$

While the Aquino assassination alienated Ambassador Armacost, the growing strength of the New People's Army further alarmed the Reagan administration. In 1984, the Senate Committee on Foreign Relations published a staff report asserting that the NPA would reach strategic parity with the armed forces within three to five years. 174 The potential threat was widely reported in the news media in the United States, which affected Congress and the Reagan

171 Bonner, Waltzing with a Dictatox, p. 349.

172 Raymond Bonner, Waltzing with a Dictator, p. 351.

173 Bonner, Waltzing with a Dictator, p. 352.

171 Friend, "Marcos and the Philippines," p. 579. 
administration, who feared that the Philippines would become another Vietnam. ${ }^{175}$ Moderate Filipinos were as reluctant as the United states to see the Philippines threatened by communism. Particularly the Catholic Church, led by Cardinal Jaime Sin, walked a fine line between acknowledging the desperate economic conditions affecting the majority of Filipinos as well as brutal political repression, and condemning those priests and nuns who openly followed the Marxist movement, believing in their own brand of liberation theology. 176 However, he did not condone Marxism or any type of violence. Cardinal sin's involvement is important, however, because the Philippines is predominantly Catholic, and the Church has great ability to mobilize the population

175 Fred Brown, "Creating the Environment for a Transition" in Authoritarian Regimes in Transition, p. 312 .

176 Liberation theology was a product of Vatican II, and holding that the priest had an obligation to serve the victims of poverty and oppression, and to address the salvation of their souls as well their temporal poverty. Particularly young priests believed that this justified social protest and agitation, conferring the right and/or duty to engage in social revolution. The Philippine Catholic hierarchy had traditionally emphasized attention to the soul rather than man's temporal condition; those who had been critical of the hierarchy quickly exploited the opportunity vatican II offered to legitimize their views. Cardinal sin was forced to appease both conservative and progressive elements; he refused to censure those openly sympathetic to Marxists, but also refused to condone violence. He took it upon himself to complain of military abuses, and even rebuked Pope John paul II's criticism of his political activity by reasoning that since politics was a human activity, it therefore involved morality---and no one was better qualified to explain morality than a priest. William Chapman, Inside the Philippine Revolution (New York: W.W. Norton \& Company, 1987), p. 200 and p. 212. 
if it so chooses. Cardinal sin successfully channeled protest into non-violent channels, and it can be argued that his actions prevented the radicalization of the Philippines. By mobilizing the church, Marxism was not allowed to be the only avenue of protest against the Marcos regime.

The May 1984 elections were a further indication of the pressure on Marcos to make changes towards liberalization. The Aquino assassination had pushed the middle class, the Catholic Church, and the business community into open opposition to Marcos. ${ }^{477}$ While both Imelda and Ferdinand Marcos spent a considerable amount of money to ensure the success of the Marcos own Kilusan Bagong Lipunan (KBL) party, the opposition won 60 seats in the legislature (approximately one-third of the total) ${ }^{478}$, and was particularly strong in Manila, much to Imelda Marcos' dismay since that was her province. Another setback occurred in October 1984 when the Agrava Commission, which had been charged with the investigation of the Aquino assassination, returned a report which concluded that a military conspiracy existed, although the commission members differed as to whether it included Chief of staff General Ver, who commanded the military and was one of Marcos friends and

177 Schirmer, The Philippines Reader, p. 275.

178 Armacost, "Philippine Aspirations," p. 301. 
close advisors. 479

Also in 1984, a story was published in the san Jose Mercury-News, which won a Pulitzer Prize. It exposed the extent of Marcos wealth for the first time, pulling together what a lot of different sources knew about Marcos wealth and crony capitalism. ${ }^{400}$

The Reagan Administration was still not willing to distance itself from the Marcos regime. A National Security Study Directive (NSSD) prepared by John Maisto, the head of the Philippines desk at the state Department, ${ }^{181}$ opted for a policy of continued support for Marcos with an emphasis of pressure to make reforms and prepare for a peaceful transition to a successor. ${ }^{182}$ The administration argued for the continued provision of economic and military aid in 1985 , and the Congress did authorize $\$ 70$ million in military aid and $\$ 95$ million in economic aid which would be sent through the normal channels in the Marcos government. ${ }^{183}$ In

179 Claude Buss, Cory Aguino and the people of the Philippines (Stanford: Stanford Alumni Association, 1987), p. 23 .

180 John Maisto, "Reform: The Bedrock of U.S. Policy" in Authoritarian Regimes in Transition, p. 318 .

181 Mr. Maisto was married to a Filipino from a wealthy sugar family in Negros, and had considerable familiarity with the philippines before martial law through extended vacations with his spouse.Bonner, Waltzing with a Dictator, pp. 344,362 .

402 Bonner, Waltzing with a Dictator, p. 363.

183 Bonner, Waltzing with a Dictator, p. 371. 
keeping with the new policy, however, Marcos received three visitors in January 1985 alone: Paul Wolfowitz, assistant secretary of state for East Asia; Richard Childress, the Asian expert in the NSC; and Richard Armitage, the Assistant Secretary of Defense for International security Affairs. 184 specifically, the reforms included the professionalization of the military, revitalization of the economy through allowing markets to freely operate outside of monopolization, and the continued opening of the political system, culminating in a presidential election in 1987. 185 However, the embassy was not naive about the prospects for Marcos carrying out such measures, because it would have meant risking the fortunes of family members and friends in a market system instead of a monopolistic one, and turning over the military to people who might not be loyal to him. ${ }^{186}$ The eventual acquittal in December 1985 of General Ver and the other 25 defendants for the Aquino assassination seemed to confirm this belief, and it "tore the last shred of respectability from the Marcos version of the traditionally independent judicial system." 487

The Congress, in the form of the senate Foreign Relations Committee had also become convinced that Marcos

184 Bonner, Waltzing with a Dictator, p. 363.

185 Armacost, "philippine Aspirations," p. 301.

486 Armacost, "Philippines Aspirations," p. 301-302.

187 Buss, Cory Aquino and the People, p. 23. 
was beyond reform. In August of 1985, a committee staffer named Frederick $z$. Brown, who had travelled widely in the Philippines that year reported that Marcos was unlikely to reform and had successfully ignored U.S. pressure because he felt confident regarding the United states need for continued access to the Clark and subic bases. 188 Also, he acknowledged that reforms ran counter to Marcos' interest, and that the Philippine president hoped to stay in power indefinitely, without yielding to the opposition or U.S. recommendations. ${ }^{489}$

The pressure on Marcos continued, with a visit from CIA director william Casey in May, followed by a visit in october by senator Paul Laxalt. ${ }^{190}$ Laxalt's mission was to convince Marcos that President Reagan was serious about requesting reforms. ${ }^{191}$ While the pressure may have been mild, it was another expression of the Reagan Administration's concern with the situation in the Philippines. ${ }^{192}$ Finally, on November 3 via the television news program This Week with David Brinkley, Marcos announced that he would hold elections, and allow United states

488 Bonner, Waltzing with a Dictator, p. 379.

189 Bonner, Waltzing with a Dictator, p.379.

490 Schirmer, The Philippines Reader, p. 278.

191 Bonner, waltzing with a Dictator, p. 382.

192 Maisto, "Reform: The Bedrock of U.S. Policy," p. 318. 
observers to monitor the vote. ${ }^{49}$ This move has been widely regarded as a crucial error, for he was unable to find a pretext to maneuver himself out of the elections once the date was set. His motivation seems to have been concern over U.S. perceptions of his legitimacy. 191

Cardinal sin was responsible for convincing the disparate opposition groups to unite in support of the candidacy of Corazon Aquino. ${ }^{195}$ As Benigno Aquino's widow, she already commanded great respect and affection; she also was an effective speaker, whose sincerity was evident and inspiring. Her campaign itself remains an interesting phenomenon because she didn't have the benefit of extensive television and radio coverage (all 3 television stations were operated by Imee Marcos, daughter of Ferdinand and Imelda). ${ }^{496}$ Her speeches were clearly heartfelt and sincere, speaking of the national and international shame which the Philippines had suffered because of the corruption engendered by the Marcos regime. She also had the support of the Church which proved crucial during the final showdown. At her final rally in Luneta Park in Manila, onehalf million people attended. ${ }^{497}$

193 Bonner, Waltzing with a Dictator, p.386-387.

494 Bonner, Waltzing with a Dictator, p. 388 .

195 Buss, Cory Aguino and the People, p. 27.

196 Buss, Cory Aguino and the People, p. 28.

197 Buss, Cory Aquino and the People, p. 32. 
The election was held on Friday, February 7. Senator Paul Lugar, the head of the Senate Foreign Relations Committee, led a team which observed the elections. Senator Lugar suspected fraud and said so early on, to the dismay of other members of the team. ${ }^{48}$ At a meeting on sunday, February 9, Ambassador Bosworth informed the team that they were reporting to Washington that there had been a systematic effort to limit the vote, and Lugar concurred, relaying that the voter registration lists had been purged of 10 to 40 percent of the electorate. ${ }^{49}$ The team was in disagreement regarding how critical their statement should be of the election process. ${ }^{500}$ What ultimately changed many members minds was the walkout, at great personl risk, of government computer workers who were tallying the vote.$^{501}$ They sought protection in Our Mother of Perpetual Help church, where they spoke with team members who came away with a different perspective. ${ }^{502}$

The next drama occurred when President Reagan, at a news conference, commented that there may have been cheating on both sides, which infuriated Aquino and demoralized

Bonner, waltzing with a Dictator, p. 414.

199 Bonner, Waltzing with a Dictator, p. 414-415.

500 Bonner, Waltzing with a Dictator, p. 415 .

501 Bonner, Waltzing with a Dictator, p. 416.

502 Bonner, Waltzing with a Dictator, p. 416 . 
embassy personnel. ${ }^{503}$ Ambassador Bosworth personally met with Mrs. Aquino to diplomatically intimate that she should ignore the President's remarks, and that he would change his mind. ${ }^{501}$

On the same day as Reagan's remarks, one of Aquino's campaign advisor's was gunned down by six masked gunmen in Manila. ${ }^{505}$ This was reported in the United States, as was the walk out by the computer workers; Marcos himself was also given a lot of air time, but it did little to enhance his image. ${ }^{506}$ The press coverage remained sympathetic to Aquino, and Congress started to openly criticize Marcos, calling for his resignation. 507 Both Marcos and Cory Aquino had realized that the American press and the American government were crucial allies, and both tried to bolster their image in the U.S. press by hiring American public relations advisors. ${ }^{508}$

However, the Filipinos didn't wait for Washington to adjust its policy; the Catholic Bishop's Conference of the Philippines published a pastoral letter which condemned the

503 Buss, Cory Aquino and the People, p.35 and Bonner, Waltzing with a Dictator, p. 423 .

501 Bonner, waltzing with a Dictator, p. 425.

505 Bonner, Waltzing with a Dictator, p. 422.

506 Bonner, Waltzing with a Dictator, p. 421-422.

507 Bonner, waltzing with a Dictator, p. 422 .

508 Bonner, Waltzing with a Dictator, p. 424. 
electoral fraud, and stated that the Marcos government had no moral basis because of these actions and called for nonviolent struggle for justice. ${ }^{509}$ At this point, Reagan dispatched Philip Habib as a special envoy; he met with more than 100 individuals and came away convinced that Marcos had little legitimacy left and was able to convince President Reagan. ${ }^{10}$ The white House issued a statement prior to Habib's return, however, which conceded that the fraud had been perpetrated by the ruling party. ${ }^{511}$

During the third week in February, everything finally unraveled for Marcos. In four short days, Marcos was routed in a nonviolent demonstration of power. On February 22nd, after notifying Cardinal sin and the American and Japanese ambassadors, Defense Minister Juan Ponce Enrile and Lieutenant General Fidel Ramos demanded that president Marcos resign. 512 In an extraordinary two hour interview, Enrile confessed to committing election fraud, and that the assassination attempt on him which was the original justification for martial law never existed. ${ }^{513}$ Cardinal $\mathbf{s i n}$, meanwhile, asked Filipinos, via the church radio station, to

\footnotetext{
509 Bonner, waltzing with a Dictator, p. 425.

510 Bonner, Waltzing with a Dictator, p. 430 .

511 Bonner, waltzing with a Dictator, p. 431.

512 Buss, Cory Aquino and the People, p. 37.

513 Buss, Cory Aquino and the People, p. 37.
} 
go into the streets to protect the rebels. 514 In response to this appeal, crowds surrounded the military barracks where Enrile and Ramos were staying. 515 Marcos countered with announcing on television that he and the first Lady had been the targets of an assassination plot. ${ }^{516}$ The next day, General ver ordered 500 men in tanks to attack the rebels; however, the streets were filled with non violent protestors from all different classes, armed with rosaries. ${ }^{511}$ At a standoff, the tanks retreated. 518 The white House, now fully into the crisis mode, issued a statement which assigned "overwhelming" responsibility for fraud to the ruling party. ${ }^{519}$

As the crisis continued, more and more of the military joined the rebels. 520 By Monday the 24 th, rebel helicopters had dropped grenades on the presidential palace, and attacked the government air base near Manila. 521 By six p.m., the white House issued another statement that was the product of extensive discussions earlier that day by

514 Buss, Cory Aquino and the People, p. 37.

515 Bonner, Waltzing with a Dictator, p. 435.

516 Buss, Cory Aquino and the People, p. 37.

517 Buss, Cory Aquino and the People, p. 39.

518 Buss, Cory Aquino and the People, p. 39.

519 Bonner, Waltzing with a Dictator, p. 437.

520 Bonner, waltzing with a Dictator, p.435.

521 Buss, Cory Aquino and the People, p. 40 . 
Reagan's chief staffers, including Chief of staff Regan, Defense secretary Weinberger, secretary of state schultz, National Security Adviser John Poindexter; Philip Habib and Michael Armacost, the Chairman of the Joint Chiefs Admiral Crowe, and of course President Reagan. 522 Habib and Schultz were finally able to convince the president that Marcos had was going to be forced to leave. ${ }^{523}$ Later that day the white House issued a statement that the United states would end military aid if force was used against the rebels. ${ }^{521}$ Reagan also sent a message to Marcos to ask if he wanted asylum, in order to prevent him from facing the same situation as the Shah did, wandering from state to state. ${ }^{525}$ on Monday morning, in response to an intercepted message which ordered the armed forces to attack the rebels, the white House issued another public statement calling for a "peaceful transition to a new government." 526

On Tuesday, Marcos succeeded in reaching senator Laxalt on the Hill, and asked Laxalt to ask the president if Marcos could resign when his term expired and then stay in the country. ${ }^{521}$ Laxalt promised to check with the president, and

522 Bonner, Waltzing with a Dictator, p. 437.

523 Bonner, Waltzing with a Dictator, p. 438 .

524 Bonner, waltzing with a Dictator, p. 438 .

525 Bonner, waltzing with a Dictator, p. 438 .

526 Bonner, Waltzing with a Dictator, p. 439.

527 Bonner, Waltzing with a Dictator, p.439-440. 
then called on Tuesday morning, unable to say what President Reagan wanted Marcos to do; in response, Marcos asked what Laxalt thought he should do. ${ }^{28}$ Laxalt's reply was to advise Marcos to leave. ${ }^{529}$ Shortly after 10:00 a.m., Cory Aquino took the oath of office as President. ${ }^{530}$ In a grotesque parody, Marcos did the same at twelve o'clock at the presidential palace; however, the broadcast of the ceremony was knocked off the air as the rebels captured the last television station. ${ }^{531}$ Marcos seemed $i 11$ and unaware of his surroundings. 532 Earlier that day, he had phoned Ambassador Bosworth, requesting a military escort to leave the palace. ${ }^{53}$ At 9:00 p.m. he was taken by helicopter to Clark Air Base, where he boarded a plane, along with his family and General Ver, for Guam and then Hawaii. 534 At that point, Ambassador Bosworth telephoned President Aquino with his congratulations. 535

Within two hours after Marcos departed, Secretary of state schultz read a statement extending recognition to

528 Bonner, waltzing with a Dictator, p. 40.

529 Bonner, Waltzing with a Dictator, p. 440 .

530 Buss, Cory Aguino and the People, p. 41.

531 Buss, Cory Aquino and the People, p. 41.

532 Buss, Cory Aquino and the People, p. 41.

533 Buss, Cory Aquino and the People , p. 41.

534 Bonner, waltzing with a Dictator, p. 440 .

535 Bonner, waltzing with a Dictator, p. 440 . 
President Aquino, in addition to praise for the courage of President Aquino and the Filipino people. ${ }^{536}$ This was followed by assurances of military and economic assistance, and visits from Congressman stephan Solarz and secretary Weinberger. 537

\section{ANALYSIS AND COMPARISON OF THE CRISIS PERIOD}

It is interesting to note that the immediate events preceding the crisis period in each state were remarkably similar in some respects. There was a strong economic downturn which was in part a result of world recession (complicated by the debt crisis for the Philippines), and in part because of grave mismanagement of the economy. Both the Shah and Marcos had spent considerable time and effort in building up their military establishments, although the scale was much larger in Iran because of oil revenues and the Shah's obsession with arms purchases. In each state, corruption among the elite was a problem that was widely acknowledge and resented by the urban middle class. There was evidence in both Iran and the Philippines that corruption occurred to such a great extent that it damaged the economy and impoverished the average citizen. In Iran, there was further outrage at the waste of oil money which

\footnotetext{
536 Buss, Cory Aquino and the People, p. 173.

537 Buss, Cory Aquino and the People, p. 173.
} 
could ensure prosperity for future generations. In each state, the military provided an important prop for the regime; however, military desertions were an important component in the downfall of each leader. Finally, each was forced to pursue at least superficial liberalization, but was unable to enact real reform because it would have endangered the centralization of power which maintained each regime.

These commonalities notwithstanding, U.S. awareness of these conditions greatly differed in each country and affected the timeliness of the response which the United states was able to make. In the Philippines, the United states embassy had the benefit of being in a state where the opposition spoke the same language and was eager to meet with embassy personnel. When Aquino was assassinated, the embassy could accurately assess the importance of the event, through contact with Filipino leaders such as Cardinal sin, and leading entrepreneurs from the Makati Business club. Through these contacts, the embassy was aware of the strength and growth of the opposition, despite the limits Marcos placed on the press, and the extent to which martial law intimidated the opposition. Even with the typical Filipino attitude of "Bahala $\mathrm{Na}, "$ which is roughly equivalent to "God will provide," it became apparent after Aquino's assassination that the middle class, large sections of the elite, and the military had become more predisposed 
to take action against Marcos. In turn, the importance of the information which the embassy passed on to the state Department was accurately assessed by John Maisto, who had a personal connection with the Philippines. U.S. policy makers were able to jump on the bandwagon at the right time because of this awareness.

This is in extreme contrast to Iran. The embassy personnel had, for the most part, no knowledge of the language. They associated with the same individuals who surrounded the Shah, and were unable to make contacts which would have given them a different view of the strength and depth of the opposition that was building over the years. In part, the limits were imposed by the sensitivity that the Shah exhibited towards intelligence gathering. The United states considered the twin benefits of oil and the maintenance of listening posts to the soviet union too important to jeopardize. Even if intelligence collection was attempted, the embassy could never be sure whether the contact was a SAVAK informer, since they were pervasive. Also, SAVAK's own intelligence gathering capabilities were admirable; people were frightened to say too much to anyone, because SAVAK had a way of finding out. All of these restraints combined to make reporting poor.

This led to another deficit, which was an inability on the part of the embassy to judge the extent of the disruption which the Shah's modernization program had 
caused. Academic experts like Richard Cottam, Marvin Zonis and James Bill were aware of the dislocation; but the average businessman, technician, or U.S. government employee had no means of judging the extent or the effects of rapid changes in Iranian society. While large slums are a good indication of poverty, it's amazing to realize that subsequent U.S. administrations from Nixon to Carter were unaware of the extent to which social mobilization and change had occurred. Perhaps if there had been greater involvement by A.I.D. or other U.S. assistance as there was in the Philippines, the assessment might have been more accurate.

Finally, the embassy and the administration seemed unable to take the religious aspect of the revolution seriously. This was in part because they were unaware of the role that shi'ism played in Iranian culture, but it also represents a type of chauvinism. While the resurgence of a militant Catholicism might be readily understood, the same commitment to Islam on the part of Iranians was somehow discounted. There was an assumption that modernization meant secularization; this may have been true for the people that the embassy associated with, but it was not true for the majority of individuals who were extremely disadvantaged. It was readily accepted by U.S. policy makers that Cardinal sin could be mobilizing the population through political acumen and church radio, but the same credit was never given to 
Ayatollah Khomeini and his followers.

Another aspect of the crisis involves the perceptions about each leader, and when those perceptions began to change. In the Philippines, the U.S. Congress and embassy had an accurate idea regarding Marcos venality after 1984 when the story regarding his personal wealth was reported in the San Jose Mercury-News. The consensus in the state Department regarding Marcos venality was echoed in Congress within the Senate Foreign Relations Committee. Also, anyone with a passing knowledge of the Philippines realized that Marcos was the last in a long line of corrupt Presidents. It had become apparent, however, that he was possibly the winner in that contest; the scale of corruption disabled the state in its ability to serve even a small portion of Filipinos.

In Iran the monolithic image of the shah wasn't challenged until November 9, 1988, eleven months after the demonstrations began. Part of this was due to Ambassador Sullivan's poor reporting of the Shah's condition, since he was ill with cancer at the time. It was also a result of the cyclical nature of the demonstrations, which occurred every 40 days. There were periods of calm which made it appear as if the Shah had the situation under control. However, the alternate policy of cracking down and then liberalizing should have indicated an indecisiveness which was part of the Shah's character. One of the valuable aspects of George 
Ball's assistance during the crisis was that his perceptions of the Shah were formed prior to the Nixon/Kissinger era. He was aware of the assessments from the $50 \mathrm{~s}$ and $60 \mathrm{~s}$ which recognized the Shah's basic indecisiveness.

Congress also was much more involved in the events which unfolded in the Philippines. Since economic assistance came up for review every year, senators and Congressmen were much more likely to hear criticism of the Philippines. 538 Iran was under no such restrictions, and despite criticism of arms sales in 1975 and 1976, Iran's posture towards Israel, its role as a leader in OPEC, and the magnitude of the shah's military purchases which recycled petrodollars eliminated a lot of criticism. Congress didn't appreciate the violence used by some of the Iranian students protesting against the shah, and they didn't gain a lot of sympathy, unlike the organized and sophisticated opposition which Filipinos mounted in the United states. ${ }^{539}$

still another difference involved the amount of contact which the opposition had with the United states. Although the Philippine opposition might deplore continued U.S. aid, they were also familiar enough with the processes of Congress and the executive, as well as the particular

538 Hans Binnendijk, "Congress---Not an Important Actor" in Authoritarian Regimes in Transition, p. 24.

539 Binnendijk, Authoritarian Regimes in Transition, p. 25 . 
character of each administration to recognize they could convince some if not all to support them. Khomeini and his followers, however, knew little about the political processes of the United states. They had a great distrust of the United states machinations in Iranian affairs. The opportunities for rapprochement were limited by the cultural limits of Khomeini's followers, as well as their lack of desire for contact with the United states. All envoys would be equally deceptive, pursuing an agenda that benefitted the United states, and thus could not be beneficial for Iran. Also, those who did appear to advocate a lessening of opposition to the west were executed, not unlike suspected royalists during the French Revolution.

Another important aspect to compare involves the type of regime which assumed power. While both Aquino and Khomeini had great legitimacy, Aquino was a moderate leader while Khomeini was a radical one. Aquino was concerned with the practical realities of economic survival for the Philippines, which depends in large part on U.S. financial support in terms of trade and aid. Aquino didn't preach a radical agenda, but instead sought to return the Philippines to some type of order which would serve the majority of Filipinos, rather than enrich the Marcos family. Her goals of ending corruption and restoring political liberties were entirely reasonable. In contrast, khomeini's goal was to create an Islamic state in Iran, and to do this he 
radicalized the population through continued political uncertainty in the government. He successfully coordinated the rise and fall of four prime ministers after the shah left, in order to consolidate his power and implement a theocratic regime.

This leads to another aspect of comparison, namely the character of each revolution. While the government which triumphed in Iran was theocratic in nature, the revolution was a political one in the sense that a new group, the radical clerics, assumed power. Clerical approval and disapproval of government policies was part of Iranian political history, and with the revolution the clerics triumphed over all other secularized groups. Religious values became intertwined with ousting the shah and rejecting the Western influences he represented. Embracing traditional shi'ism was a means of reaffirming Iranian values and nationalism. The shah was the symbol of the modern and Westernized Iran which benefitted few Iranians. The Philippines, on the other hand, seemed to return to a status quo where political elites contested elections between themselves. The difference was that the elite with a conscience finally came into power. The Philippines reacted against a particular dictator and his perversion of a political system that was already corrupt. While the events of the Philippine revolution were dramatic, it was truly on a different scale than that of Iran. These two factors, the 
type of revolution and the type of leader, may partially account for the ability of U.S. policy makers to effectively implement a policy which resulted in continuing good relations. 
CHAPTER VI

CONCLUSION

The analysis in this paper has centered on the differences between the two states during the tenure and crisis periods. It is evident that the United states did a better job of coordinating policy and coping with events in the Philippines during both time frames. Part of this was the result of greater familiarity with the personalities involved, and greater experience both in the embassy and state Department with the political culture of the Philippines. There was also a consensus to convince the President to "let go" of a long-time friend and U.S. ally. which united more individuals as the crisis progressed. This presents a contrast to Iran where policy coordination was difficult, information about the crisis was poor, and the President possessed no steadfast position on what action to pursue. Both the Shah and the United states found it difficult to cope with the revolutionary zeal of Khomeini's followers, believing that they would ultimately compromise.

In addition to this assessment, however, some comment is necessary regarding the relative importance of the tenure period relationship versus the crisis management period, and how each affected the outcome of subsequent relations 
between the United states and each country. Also, an important question in this paper is the asserted over identification of each leader with the United states, and how this affected long term relations after the shah and Marcos departed. Thus, the conclusion will discuss the relative merits versus demerits of U.S. support and influence over each regime, and the effects of its concrete expression in terms of foreign aid reliance.

\section{TENURE VERSUS CRISIS}

In evaluating the tenure and crisis periods, it is difficult to assert that one is ultimately more important than the other in determining the varying outcomes. Rather, the tenure period set certain preconditions in terms of each relationship and created perceptions that affected the way each crisis played itself out between the United states and each state.

The continuing good post-Marcos relationship between the United states and the Philippines is due in part to the weight of the past colonial relationship. Filipinos perceived their country in relation to the United states as a type of a special friendship between the two countries, and they valued it even though it wasn't perfect. The shift that occurred with the Aquino revolution was important for Filipinos, because they acted to oust a leader who the 
United states had approved and supported with economic and military aid. There was a recognition that the U.S. had acted in its own primary interests by supporting Marcos, and not those of the Philippines, despite the special relationship. However, the United states remained a strong presence because the Philippines relied on U.S. economic support and the presence of U.S. military personnel on the bases. The United states maintains an ubiquitous presence in Philippine life which is difficult to comprehend from the other side of relationship.

Also as a result of the colonial relationship and subsequent closeness, United states intervention in the Philippines after independence wasn't perceived as an absolutely malign influence as it was in Iran, although it was resented. While part of the Filipino political elite advocated nationalism and self-reliance, the group had a long history of cooperation with the United states. This pattern of reliance and cooperation established during the tenure period helped to moderate the Filipino response after the revolution. The Aquino presidency marked the assertion of Philippine self-government, rather than a rejection of the United states.

Iran-U.S. relations were at the opposite end of the continuum. What U.S. policy makers generally knew of the Middle East in terms of culture and history was much less than their knowledge of Philippines. For Iran's 
revolutionary policy makers, who were outside the westernized group around the shah, the perception was one of traditional Iranian xenophobia towards a great power. While some moderates allied with Khomeini had a better understanding of the United states, this wasn't true for the average Iranian caught up in revolutionary fervor. The enduring perception for many Iranians, established during the tenure period was the Shah's overthrow of Mossadeq coordinated by U.S. spies. It was easy for Iranians to equate U.S. interference with British and Russian interference earlier in the century.

In addition, the United States picture of Iran as a modern, Westernized regional power was created by the Shah, who successfully cultivated the image of an effective leader through bold foreign policy initiatives and OPEC leadership. U.S. policy makers were unwilling to alter this perception or challenge the shah too greatly because of the benefits for U.S. foreign policy were too great. Iranians resented the well-known U.S. intervention in the 1953 coup, and then had to submit to increasingly severe political repression from SAVAK, which was trained by the CIA. Their pride in the Iranian state as a regional superpower was tempered with the costs of political repression at home and the loss of traditional ways of life as Iran rapidly modernized in ways that didn't benefit the majority. The infiltration of Western thought and lifestyle wasn't tempered with any 
beneficial intervention by the United states, except perhaps U.S. intervention during the Azerbaijan crisis after world War II. In this manner, each side suffered from false and limited perceptions, and unlike the U.S.-Philippine relationship, there wasn't any residue of goodwill created during the tenure period towards U.S. involvement in Iran.

The second observation concerns the change in leverage between the United states and each country. In a simple image, imagine a see-saw which is weighted on side A. This represents the United states, which prior to the martial law rule of Marcos and the Shah's declaration of the white Revolution, maintained a certain amount of influence over each leader in terms of reforms and other quid pro quos. This was expressed in the provision of foreign aid to fill budget deficits, and in the Philippine case also the continued maintenance of trade. However, both Marcos and the Shah managed to shift some of that weight towards side $B$ as they consolidated power within their regimes. Increasingly, the United states percieved each man as being in control of domestic reforms and policies. This perception had the effect of making U.S. less willing to criticize internal developments.

Also, some of the weight slid towards the other side, as the United states came to rely more on foreign oil from the Middle East and the strategic importance of the military bases in the Philippines increased. The United states found 
Soviet presence in Cam Ranh Bay disturbing, once again seeing soviet attempts at expansion. Iran was a significant oil supplier, but more importantly, the shah was important in OPEC, where Western states needed an ally. Finally, changes in U.S. foreign policy outlook also allowed some weight to shift after the repercussions of withdrawal from the Vietnam crisis. The United states was no longer interested in making the necessary investments to influence events in other states, instead following a hands-off policy unless directly threatened.

The effect of this cumulative shift in leverage was that the U.S. found itself over-reliant on Iranian oil and the Shah's leadership, and gradually lost the ability to influence the shah towards reform. He no longer needed either revenue assistance or international political prestige; he only needed weapons and equipment, which it benefitted the U.S. to supply. Although it can be argued that even if the U.S. had pushed for reforms the shah would not have pursued it, the perception of the United states in the eyes of many Iranians would have been much better. Iranian disappointment over Carter's failure to follow through on his human rights rhetoric caused a loss of credibility in the eyes of the opposition.

The gradual loss of leverage during the tenure period affected the U.S.-Iran response much more than the U.S.Philippine response because not as much leverage was lost in 
the Philippines. Partly this was because of the continued provision of foreign aid, but it was also a result of the long-term relationship that the U.S. and the Philippines had maintained. Also, the United states relied on Iran and the Shah's willingness to help manage a tempestuous region for U.S. foreign policy. These elements combined to create a greater loss of leverage in Iran.

\section{OVER IDENTIFICATION}

To say that military and economic aid maintained these leaders in power ends up as an oversimplification. Just as the relationship between economic change and political change is often indirect, so is the relationship between foreign aid and regime maintenance. However, the assiduousness with which each leader pursued foreign aid when the perceived need was there dovetailed with U.S. goals in the cold War. Iran was out of the foreign aid reliance relationship after 1967, while the Philippines has never emerged. This probably accounts, in part, for the Shah's independence from the United states, despite the fact that he still needed the U.S. as an arms supplier. Neverless, he still remained over identified with the United states in the minds of many Iranians, even though his regime was maintained through political repression and oil revenues.

Two facets of the foreign aid relationship with these 
states are important and have bearing on the question of overidentification. First, it is alledged that foreign aid was used to further the political ends of each leader, and the United states used foreign aid to keep these individuals in power. The evidence in the Philippines is mostly anecdotal; there is acknowledgement that corruption was widespread, and certainly aid flows after the declaration of martial law increased. While Filipinos expected U.S. support of Filipino presidents, they resented U.S. support of Marcos during the martial law period. In terms of the shah, the consensus is that U.S. aid supported the government and covered existing budget deficits at a time when the Shah was struggling to assume control, subduing the Tudeh party and weakening the National Front, allowing him the time to gain control and develop SAVAK. The point is that U.S. aid was supplied at a time when each leader was consolidating his power. While foreign aid continued on a long-term bas is in the Philippines as opposed to Iran, this may not be as important as the fact that U.S. support ennabled each leader to stay in office long enough at a crucial point in time to centralize control around themselves. While large portions Iranians and Filipinos seemed to support each leader at these "turning points" it was continued U.S. aid that allowed them to consolidate their positions afterward. This is when over identification occurred.

Second, the United states seems to have been unable to 
influence reform in any significant way. The value of reform wasn't questioned and U.S. policymakers acknowledged that dictatorships were not a good long-term situation. However, the original end was to keep states from becoming communist as economic development corrected social inequities. Although each leader promised to improve living standards and create greater economic equity, they instead consolidated power, and elite groups became more entrenched. The United states had many ideas about the efficacy of foreign aid, but wasn't realistic about what was accomplished with it. While some conditions were ameliorated, the lack of change is the result of stated foreign aid goals such as economic prosperity and education clashing with the need for patronage and centralization. Thus foreign aid accomplished the goal of keeping each leader loyal to the United states, but fostered little internal political reform.

\section{FUTURE RECOMMENDATIONS}

If recommendations for the future are in order, they center around U.S. attitudes toward Third world leaders. While accurate intelligence is vital to U.S. assessments of political change in developing states, so is the realization that no leader is permanent. Although strong support of the Shah bought support during his regime, there wasn't any 
planned response as to what would happen if he should fail. The assumption that any regime is stable is simply erroneous, so an understanding of the opposition is necessary .

second, even if the U.S. is perceived to be supporting a repressive leader by opposing groups, U.S. pressure to mitigate the effects of regime abuses, such as torture or political repression, would engender more long-term goodwill with groups that might eventually assume power. The United states does have the leverage to do this with most states, and it constitutes better long-term planning. It also gives policy makers something to refer back to, and creates the perception that the U.S. is committed to the state, not the particular leader which governs that state.

Finally, foreign economic and military aid should be used much more cautiously. Views have changed regarding the efficacy of foreign aid to create economic and political development in an ever upward spiral. However, the view that economic development and growth will foster more benign political conditions in Third world states still exists to some degree. Aid isn't politically neutral in these states, and it should be given with that understanding. As economies mobilize, a greater rather than a lesser concentration of wealth may occur. Concurrently, many elites may find themselves strengthened rather than weakened. Thus aid may have effects opposite of those intended, and U.S. policy 
makers should be prepared for this outcome.

For future research, it would be interesting to look at a larger group of states. By enlarging the sample, patterns may become evident which are not possible to observe with a comparison of two states alone. Another suggestion concerns the dynamics between the executive, state department, and national security apparatus in confronting crises of regime downfall in these states. Reactions probably vary between administrations, but the degree to which they might be similar would be interesting. Although it was beyond the scope of this paper, the Carter and Reagan administrations seemed to handle these crises quite differently. It would be interesting to note reactions among different administrations during different crises. 
REFERENCES

Abrahamian, Ervand. Iran Between Two Revolutions. Princeton: Princeton University Press. 1982 .

Adelman, Jonathan R., ed. Superpowers and Revolutions. New York: Praeger Publishers, 1986.

Alexander, Yonah and Allan Nanes, editors. The United States and Iran A Documentary History. Frederick: University Publications of America, 1980 .

Allison, Roy and Phil williams. Superpower Competition and Crisis prevention in the Third World. Cambridge: Cambridge University Press, 1990.

Armacost, Michael H. "Philippine Aspirations for Democracy" in Authoritarian Regimes in Transition, Edited by Hans Bennendijk. Washington, D.C.: U.S. Department of State, Foreign Service Institute, center for the study of Foreign Affairs, 1987.

Bacho, Peter "Rural Revolt in the Philippines: Threats to Stability?" Journal of International Affairs, vol. 40, no. 2 (winter/Spring 1987): 257-270.

Bailey, Jennifer. "Revolutions and the International system" in Superpowers and Revolutions, edited by Jonathan

R. Adelman. New York: Praeger Publishers, 1986.

Bailey, Thomas A. A Diplomatic History of the American People. New York: Apple-Century-Crofts, 1964.

Baldwin, David A. Foreign Aid and American Foreign Policy A Documentary Analysis. New York: Frederick A. Praeger, Publishers, 1966.

Ball, Nicole. Security and Economy in the Third world. Princeton: Princeton University Press, 1988.

Bevans, Charles I. (Compiler) Treaties of the and other International Aqreements of the United states of America, 1776-1949, Dept. of state Publication 8728. Washington, DC: U.S. Government Printing office, 1974, Vol 11 . 
Bi11, James A. "Modernization and Reform from Above: The Case of Iran." The Journal of Politics, vol. 32(1) (February, 1970) 19-40.

Binnendijk, Hans (Ed). Authoritarian Regimes in Transition. Washington, D.C.: U.S. Department of state, Foreign Service Institute, center for the study of Foreign Affairs, 1987.

Brown, Fred. "Creating the Environment for a Transition" in Authoritarian Regimes in Transition Edited by Hans Bennendijk. Washington, D.C.: U.S. Department of state, Foreign service Institute, center for the study of Foreign Affairs, 1987.

Bonner, Raymond. Waltzing with a Dictator. New York: Times Books, 1987 .

Bozeman, Adda B. "Iran: U.S. Foreign Policy and the Tradition of Persian statecraft" Orbis, vol. 23, number 2 (Summer, 1979) 387-402.

Buss, Claude. Cory Aquino and the People of the Philippines Stanford: Stanford Alumni Association, 1987 .

Chapman, william. Inside the Philippine Revolution. New York: W.W. Norton \& Company, 1987 .

Cohen, Benjamin J. "High Finance, High Politics" in Uncertain Future:Commercial Banks and the Third World, edited by Richard E. Feinberg and Valeriana Kallab. New Brunswick: Overseas Development Council, 1984 .

Cottam, Richard. Nationalism in Iran. Pittsburgh: University of Pittsburgh Press, 1979.

Cottam, Richard. "Goodbye to America's Shah" Foriegn Policy 34 (Spring, 1979) 3-14.

Denton, Frank H. and Victoria Villena-Denton, Filipino Views of America. Washington, D.C.: Asia Fellows Ltd., 1986 .

Druckman, Daniel and Justin Green. Political stability in the Philippinnes: Framework and Analysis, Monograph in World Affairs, no. 22, book 3 . Denver: Graduate School of International studies, 1986 . 
Eberstadt, Nicholas. Foreign Aid and American Purpose. Washington, D.C.: American Enterprise Institute for Public policy Research, 1988 .

Friend, Theodore. "Marcos and the Philippines," Orbis, vol. 32 , no. 4 (Fall, 1988 ) 569-586.

Gasiorowski, Mark. "Security Relations between the United states and Iran, 1953-1978" in Neither East nor West edited by Nikki R. Keddie and Mark Gasiorowsksi. New Haven: Yale University Press, 1990 .

Gilpin, Robert. The Political Economy of International Relations. Princeton: Princeton University Press, 1987 .

Glahn, Gerhard von, Law Among Nations. New York: Macmillan Publishing Company, 1986 .

Golay, Frank. "Cause for Concern in the Philippines." The Journal of Asian studies, vol. XLV, no. 5 (November, 1986) 935-943.

Goldstein, Daniel M. U.S. Policy Concerning Renewal of the Military Base Agreement with the Philippines. Pittsburgh: Pew Charitable Trust, 1988.

Goldstone, Jack A. "Revolutions and superpowers" in Superpowers and Revolutions, edited by Jonathan

R. Adelman. New York: Praeger Publishers, 1986 .

Gregor, James A. Crisis in the Philippines. Washington, D.C.: Ethics and Public Policy Center, 1984.

Halladay, Fred. "The Great Iranian Revolution and Great Power Politics: Components of the First Decade" in Neither East nor West edited by Nikki R. Keddie and Mark Gasiorowsksi. New Haven: Yale University Press, 1990.

Hawes, Gary. "United states support for the Marcos Administration and the Pressures that Mase for Change." Contemporary Southeast Asia 8 (June 1986) $18-36$.

Howe, James and Robert Hunter. "United states Performance and Development Policy" in Aid Performance and Development in Western Countries studies in the U.S., U.K., E.E.C. and Dutch Programs, edited by Bruce Dinwiddy. New York: Praeger Publishers, 1973. 
Keddie, Nikki R. and Mark Gasiorowsksi (Ed.), Neither East nor West. New Haven: Yale University Press, 1990.

Klare, Michael and Cynthia Arnson. Supplying Repression: US Support for Authoritarian Reqines Abroad. Washington D.C.: The Institute for Policy studies, 1981 .

Koch, Noel. "US Security Assistance to the Third world: Time for Reapplaisal." Journal of International Affairs 40 (Summer, 1986).

Kolko, Gabriel. Confronting the Third World. New York: Pantheon Books, 1986.

Lappe, Francis Moore, Joseph Collins and David Kinley. Aid as obstacle. San Francisco: Institute for Food and Development Policy, May 1981.

Maisto, John. "Reform: The Bedrock of U.S. Policy" in Authoritarian Regimes in Transition, edited by Hans Bennendifk. Washington, D.C.: U.S. Department of state, Foreign service Institute, Center for the study of Foreign Affairs, 1987.

Mckinlay, R.D. and R. Little. "A Foreign Policy Model of U.S. Bilateral Aid Allocation" World Politics vol. $30(1)$ (October, 1977) 58-86.

Mckinlay, R.D. and R. Little. "The U.S. Aid Relationship: A Test of the Recipient Need and the Donor Interest Models" Political studies, vol. 27, No. 2, 236250 .

Morgenthau, Hans J. A New Foreign Policy for the United states. New York: Praeger Publishers, 1969.

McNeill, Desmond. The Contradictions of Foreign Aid. London: Croom Helm Ltd., 1981 .

Mosley, Paul. Foreign Aid, Its Defense and Reform. Lexington: The University Press of Kentucky, 1987.

Neher, Clark D. "The Philippinnes in 1980: The Gathering Storm." Asian Survey vol. 21 (January 1981) 261273 .

Nelson, Joan. Aid, Influence and Foreign Policy. New York: The Macmilian Company, 1968. 
Neuman, stephanie G. "The Arms Trade in Recent Wars: The Role of the superpowers." Journal of International

studies 40 (summer 1986) 77-99.

Packenham, Robert A. Iiberal America and the Third World. Princeton: Princeton University Press, 1973.

Pell, Claiborne. "Problems in Security Assistance." Journal of International Affairs 40 (Summer 1986) 33-41.

Pringle, Robert. Indonesia and the Philippines. New York: Columbia University Press, 1980 .

Ramazani, Ruhollah K. "Iran's 'White Revolution': A study in Political Development" International Journal of Middle East studies vol $5,1974,124-139$.

Riddell, Roger C. Foreign Aid Reconsidered. Baltimore: The Johns Hopkins University Press, 1987.

Rostow, W.W. Eisenhower, Kennedy and Foreign Aid. Austin: University of Texas Press, 1985.

Rubin, Barry. Paved with Good Intentions. New York: Oxford University Press, 1980 .

Saikal, Amin. The Rise and Fall of the Shah. Princeton: Princeton University Press, 1980 .

Saivetz, Carol "The USSR and Khomeini's Revolution" in Superpowers and Revolutions edited by Jonathan $R$. Adelman. New York: Praeger Publishers, 1986.

Schirmer, Daniel B. and stephen R. Shalom, The Philippines Reader. Boston: South End Press, 1987.

Schulz, Ann, "Military Expenditures and Economic Performance in Iran, 1950- 1980." Worcester, Mass.: Clark University, 1980, mimeograph. Quoted in Security and Economy in the Third World by Nicole Ball. Princeton: Princeton University Press, 1988.

Shabecoff, Philip. "Protest Movement in the Philippines Widening Rapidly," New York Times, March 12 , 1970, p. 10 .

Shalom, stephen R. The Philippines Reader. Boston: South End Press, 1987 .

sick, Gary. All Fall Down. New York: Random House, 1985. 
Steinberg, Joel D. Philippine Collaboration in World War II. Ann Arbor: University of Michigan, 1967.

Thompson, scott W. "U.S. Role in the Philippine Transition," in Authoritarian Regimes in Transition, edited by Hans Binnendijk. Washington, D.C.: U.S. Department of State, Foreign Service Institute, Center for the study of Foreign Affairs, 1987.

Thornton, Thomas $P$. The Challenge to US Policy in the Third World, SAIS papers in International Affairs. Boulder: Westview Press/Foreign Policy Edition, 1986 .

Smith, James Burkholder. Portrait of a Coldwarrior. New York: G.P. Putnam and sons, 1976.

Winham, Gilbert R. "Developing Theories of Foreign Policy Making: A Case Study of Foreign Aid" Journal of Politics, 32(1) (February, 1970) 41-70.

Wittkopf, Eugene. "Foreign Aid and United Nations Votes: A Comparative Study" American Political Science Review, vol. 76 (3), (September, 1973) 868-888. 


\section{DOCUMENTS}

CIA, Philippines: General survey. National Intelligence survey, NIS 99, July 1965. [sanitized copy released November 1980 ]

Exchange Between Prime Minister Mossadegh and President Eisenhower on the oil Dispute and the Problem of United states Aid to Iran, letter from Dr. Mossadeq to President Eisenhower dated May 28, 1953 as reproduced in Alexander and Nanes, Iran A Documentary History.

Memorandum of Conversation, by the chief of the Division of Middle Eastern and Indian Affairs (Minor) [Washington, D.C.] October 8, 1946. Reproduced in The United States and Iran A Documentary History, edited by Alexander and Nanes, p. 180 .

Organization for Economic Co-operation and Development, Geographical Distribution of Financial Flows to Developing Countries. Paris: OECD, 1977.

Political Characteristics of the Iranian Urban Middle-Class and Implications Thereof for United States Policy: A report by the Deputy Director of Greek, Turkish, and Iranian Affairs (Bowling), United states Department of state to the President March 20, 1961, as reproduced in Alexander and Nanes.

Staff Report prepared for the use of the U.S. Senate Committee on Foreign Relations, Korea and the Philippines: November 1972, Committee Print, 93rd Congress, lst session, February 18, 1973.

The Ambassador in Iran (Allen) to the secretary of state, Tehran, December 17, 1946, 2 p.m. as reproduced in Alexander and Nanes, Iran A Documentary History, p. 188 .

U.S. Bureau of the Census, statistical Abstract of the United States 1960. (81st edition) washington, D.C., 1960. p.872.

United states policy toward Iran: A Report to the National Security Council by the N.S.C. Planning Board

December 21, 1953, reproduced in Alexander and Nanes, pp. 265-267. 